\title{
Chloride Concentrations, Loads, and Yields in Four Watersheds Along Interstate 95, Southeastern Connecticut, 2008-11-Factors That Affect Peak Chloride Concentrations During Winter Storms
}

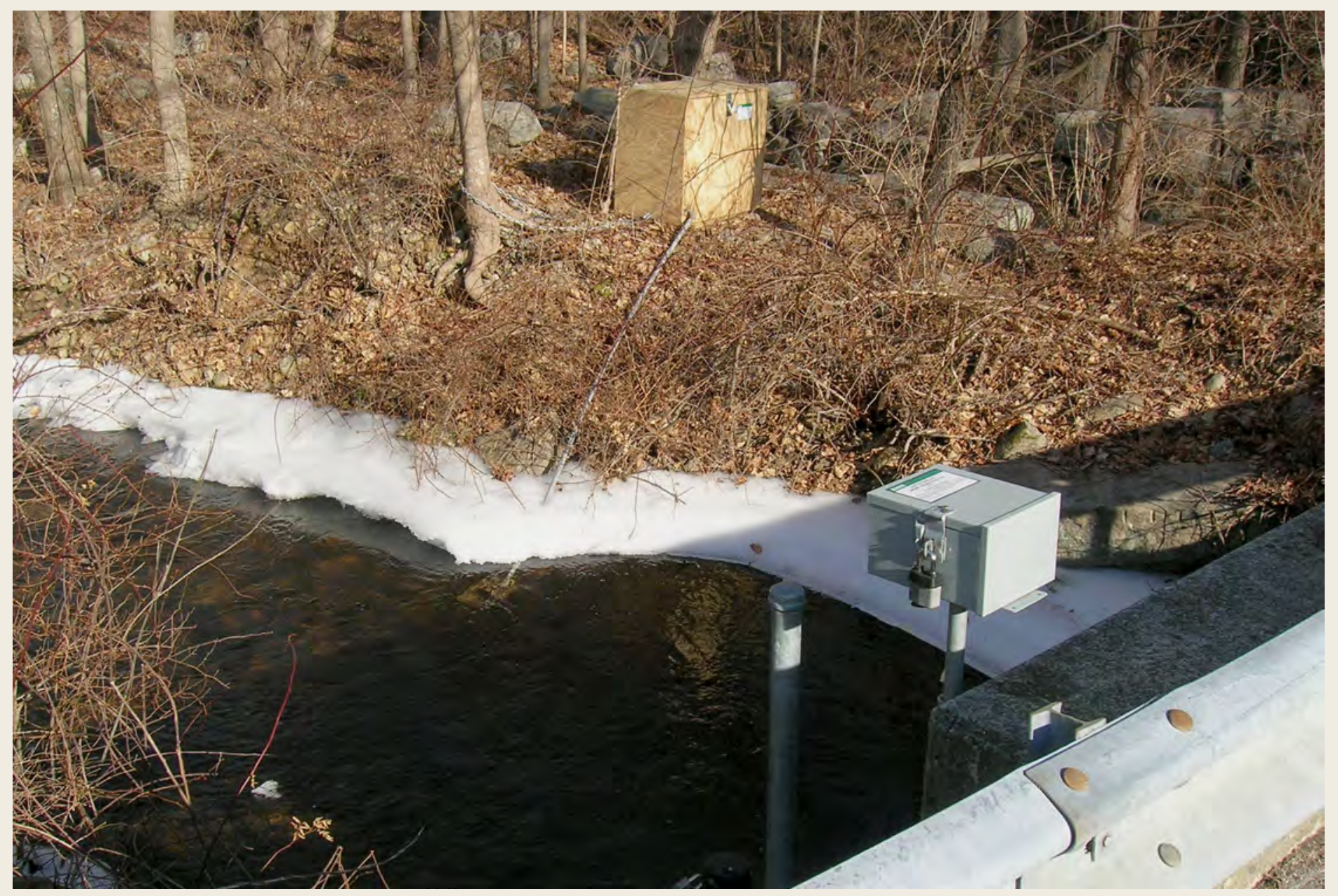

Scientific Investigations Report 2015-5057

U.S. Department of the Interior U.S. Geological Survey
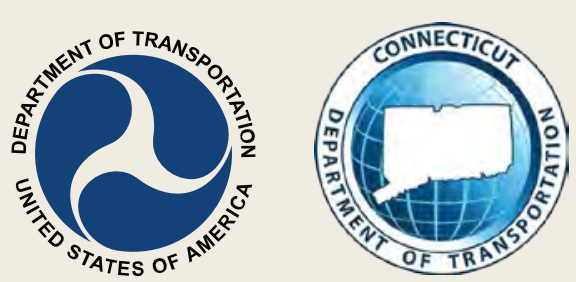
Cover. Photograph of the Jordan Brook downstream site in Waterford, Connecticut. 


\section{Chloride Concentrations, Loads, and Yields in Four Watersheds Along Interstate 95, Southeastern Connecticut, 2008-11- Factors That Affect Peak Chloride Concentrations During Winter Storms}

By Craig J. Brown, John R. Mullaney, Jonathan Morrison, Joseph W. Martin, and Thomas J. Trombley

Prepared in cooperation with the Federal Highway Administration and the Connecticut Department of Transportation

Scientific Investigations Report 2015-5057 


\title{
U.S. Department of the Interior SALLY JEWELL, Secretary
}

\section{U.S. Geological Survey \\ Suzette M. Kimball, Acting Director}

\author{
U.S. Geological Survey, Reston, Virginia: 2015
}

For more information on the USGS - the Federal source for science about the Earth, its natural and living resources, natural hazards, and the environment-visit http://www.usgs.gov/ or call 1-888-ASK-USGS.

For an overview of USGS information products, including maps, imagery, and publications, visit http://www.usgs.gov/pubprod/.

Any use of trade, firm, or product names is for descriptive purposes only and does not imply endorsement by the U.S. Government.

Although this information product, for the most part, is in the public domain, it also may contain copyrighted materials as noted in the text. Permission to reproduce copyrighted items must be secured from the copyright owner.

Suggested citation:

Brown, C.J., Mullaney, J.R., Morrison, Jonathan, Martin, J.W., and Trombley, T.J., 2015, Chloride concentrations, loads, and yields in four watersheds along Interstate 95, southeastern Connecticut, 2008-11-Factors that affect peak chloride concentrations during winter storms: U.S. Geological Survey Scientific Investigations Report 20155057, 68 p., http://dx.doi.org/10.3133/sir20155057.

ISSN 2328-0328 (online) 


\section{Acknowledgments}

The authors would like to thank Eloise Powell, Robert Turner, and Patricia Cazenas of the Federal Highway Administration; Paul Corrente, Kevin Carifa, and James Spencer of the Connecticut Department of Transportation; and the Connecticut Academy of Science and Engineering team for technical input and guidance and for providing data or information. In addition, the authors would like to thank U.S. Geological Survey employees Timothy Sargent, David Bjerklie, Daniel Lolos, Remo Mondazzi, and Timothy Frick for maintenance of streamgages and water-quality monitors, and collection of water-quality samples. 



\section{Contents}

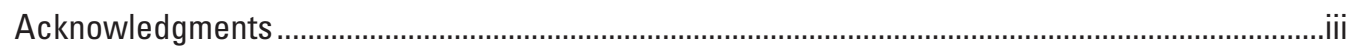

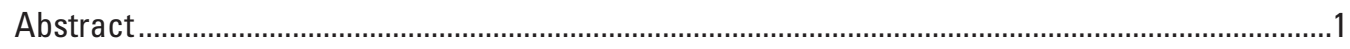

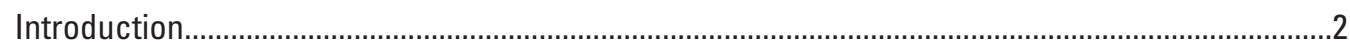

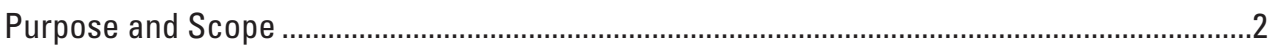

Description of Study Area ....................................................................................................

Sources of Chloride to Streams and Groundwater in the Study Area ......................................

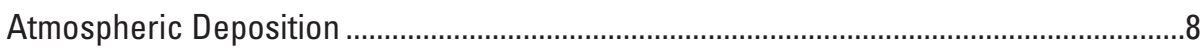

Road Deicing Chemicals and Their Application in the Study Area ...................................8

Methods of Data Collection and Analysis .................................................................................14

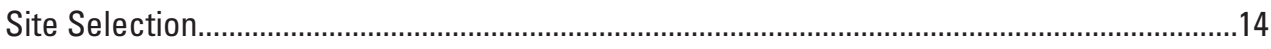

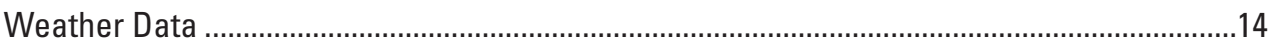

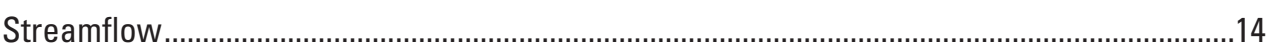

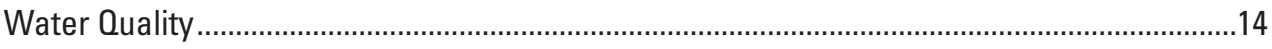

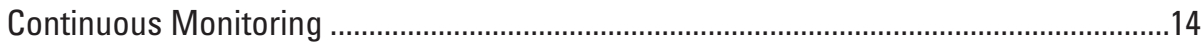

Water-Quality Sampling and Laboratory Analysis ........................................................15

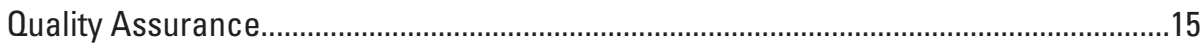

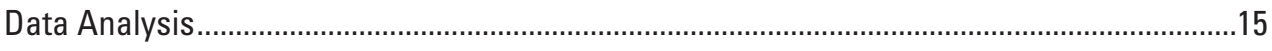

Estimation of Chloride Loads in Atmospheric Deposition ..............................................15

Estimation of Chloride Concentrations and Loads in Streams .......................................15

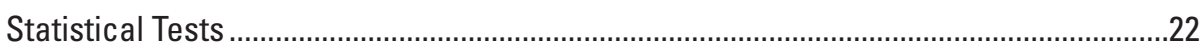

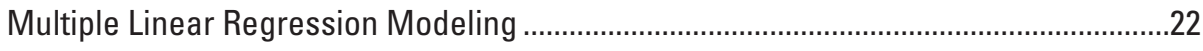

Factors that Affect Chloride Concentrations, Loads, and Yields ....................................................2

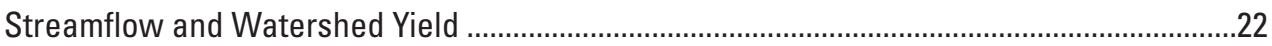

Conductance and Chloride in Four Streams Along Interstate 95 ...........................................23

Base-Flow Chemistry Upstream and Downstream of Interstate 95..............................23

Stormflow Conductance and Chloride Concentrations.....................................................26

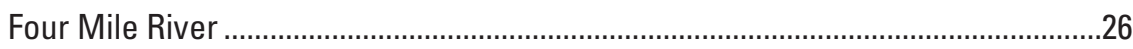

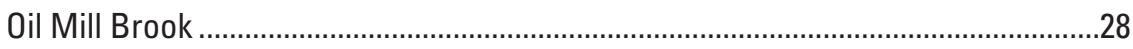

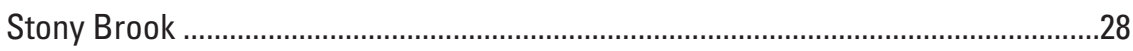

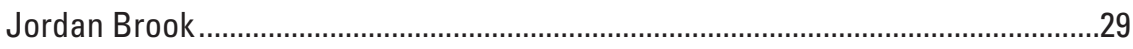

Groundwater/Surface-Water Interaction .........................................................................33

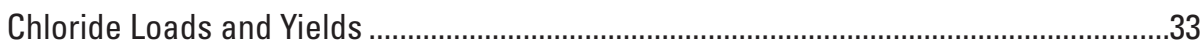

Peak Chloride Concentrations During Winter Storms ...........................................................38

Relation of Estimated Peak Chloride Concentration to Explanatory Variables ...............41

Chloride Concentrations and Aquatic Toxicity Criteria ....................................................46

Chloride Load with the Addition of Two I-95 Lanes ......................................................46

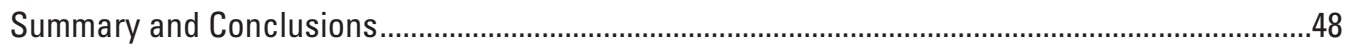

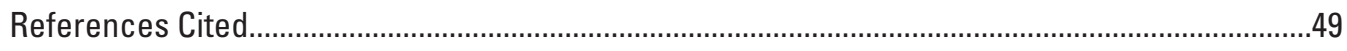

Appendix 1. Specific Conductance and Chloride Concentrations at Four Mile River, Oil Mill

Brook, Stony Brook, and Jordan Brook, Southeastern Connecticut, November 2008-

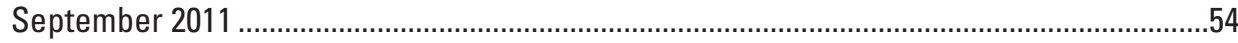

Appendix 2. Specific Conductance Measurements and Streamflow at Four Mile River, Southeastern Connecticut, November 2008-September 2011 
Appendix 3. Specific Conductance Measurements and Streamflow at Oil Mill Brook,

Southeastern Connecticut, November 2008-September 2011.

Appendix 4. Specific Conductance Measurements and Streamflow at Stony Brook, Southeastern Connecticut, November 2008-September 2011 ... 61

Appendix 5. Specific Conductance Measurements and Streamflow at Jordan Brook, Southeastern Connecticut, November 2008-September 2011

\section{Figures}

1. Map showing location of upstream and downstream water-quality monitoring sites and downstream streamgages on four selected streams along the Interstate 95 corridor study area, southeastern Connecticut.

2. Map showing land cover and water-quality monitoring sites and downstream streamgages, watershed boundaries, locations of deicing salt storage, and landfills in the study areas, southeastern Connecticut

3. Diagrams showing daily maximum and minimum air temperature and continuous precipitation at the Groton-New London airport weather station, and estimated hourly snow thickness and snowmelt at a snow observation station in southeastern Connecticut, November 2008-September 2011

4. Diagrams showing specific conductance in grab samples and continuous specific conductance at Four Mile River upstream and downstream sites, and continuous streamflow at the downstream site, and chloride concentrations measured in grab samples and estimated continuous chloride concentrations at Four Mile River upstream and downstream sites, southeastern Connecticut, November 2008-September 2011

5. Diagrams showing specific conductance in grab samples and continuous specific conductance at Oil Mill Brook upstream and downstream sites, and continuous streamflow at the downstream site, and chloride concentrations measured in grab samples and estimated continuous chloride concentrations at Oil Mill Brook upstream and downstream sites, southeastern Connecticut, November 2008-September 2011

6. Diagrams showing specific conductance in grab samples and continuous specific conductance at Stony Brook upstream and downstream sites, and continuous streamflow at the downstream site, and chloride concentrations measured in grab samples and estimated continuous chloride concentrations at Stony Brook upstream and downstream sites, southeastern Connecticut, November 2008-September 2011

7. Diagrams showing specific conductance in grab samples and continuous specific conductance at Jordan Brook upstream and downstream sites, and continuous streamflow at the downstream site, and chloride concentrations measured in grab samples and estimated continuous chloride concentrations at Jordan Brook upstream and downstream sites, southeastern Connecticut, November 2008-September 2011

8. Stiff diagrams depicting the concentrations of major ions in water at upstream and downstream monitoring sites at Four Mile River, Oil Mill Brook, Stony Brook, and Jordan Brook, southeastern Connecticut, and shallow groundwater samples from wells in forested land-use settings in Connecticut.

9. Diagram showing distributions of continuous streamflow at the downstream monitoring sites at Four Mile River, Oil Mill Brook, Stony Brook, and Jordan Brook, southeastern Connecticut, November 2008-September 2011 
10. Diagram showing estimated monthly median chloride loads in atmospheric deposition based on data from three National Atmospheric Deposition Program stations, November 2008-September 2011

11. Map showing watershed boundaries, drainage features, landfill and septic sources, water-quality monitoring sites, and the downstream streamgage at Four Mile River, southeastern Connecticut.

12. Map showing watershed boundaries, drainage features, water-quality monitoring sites, and the downstream streamgage at Oil Mill Brook, southeastern Connecticut...30

13. Map showing watershed boundaries, drainage features, landfill sources, water-quality monitoring sites, and the downstream streamgage at Stony Brook, southeastern Connecticut..

14. Map showing watershed boundaries, drainage features, landfill sources, water-quality monitoring sites, and the downstream streamgage at Jordan Brook, southeastern Connecticut.

15. Stiff diagrams depicting the concentrations of major ions in water from water-quality monitoring sites and stream piezometers in generalized cross section at Four Mile River and Jordan Brook, southeastern Connecticut, September 2010-February 2011

16. Graph showing concentrations of chloride in relation to chloride/bromide mass concentration ratios in samples collected in the study area, southeastern Connecticut, together with mixing lines between designated end members for dilute groundwater, halite, sewage, and landfill leachate.

17. Graphs showing estimated daily mean chloride load at the Four Mile River, Oil Mill Brook, Stony Brook, and Jordan Brook downstream sites, southeastern Connecticut, November 2008-September 2011

18. Graphs showing estimated peak continuous chloride concentrations associated with different precipitation types at Four Mile River, Oil Mill Brook, Stony Brook, and Jordan Brook downstream sites, southeastern Connecticut, November 2008-September 2011

19. Graphs showing deicing time as a function of estimated peak continuous chloride concentrations at the Four Mile River, Oil Mill Brook, Stony Brook, and Jordan Brook downstream sites, southeastern Connecticut, November 2008September 2011

20. Graphs showing streamflow as a function of estimated peak continuous chloride concentrations at the Four Mile River, Oil Mill Brook, Stony Brook, and Jordan Brook downstream sites, southeastern Connecticut, November 2008September 2011

21. Boxplots showing distributions of the estimated peak chloride concentrations as a function of the percentage of impervious area at the Four Mile River, Oil Mill Brook, Stony Brook, and Jordan Brook downstream sites, southeastern Connecticut, November 2008-September 2011.

22. Diagrams showing natural log of predicted peak specific conductance from multiple linear regression modeling, and natural log of observed peak specific conductance for winter storms at Four Mile River, Oil Mill Brook, Stony Brook, and Jordan Brook downstream sites, southeastern Connecticut, November 2008-September 2011 


\section{Tables}

1. Watershed areas, lengths, and shapes, distance between upstream and downstream sites, land use, numbers of salt-storage facilities and landfills, numbers of highway drains to streams, and percentage of impervious area for four selected watersheds, southeastern Connecticut

2. Classification of surficial materials for watersheds above each monitoring site in the study area, southeastern Connecticut.

3. Estimated atmospheric deposition yields and loads of chloride for the four selected watersheds in southeastern Connecticut

4. Summary of road mile lengths for Interstate 95 and other State-operated one- and two-lane roads within the Four Mile River, Oil Mill Brook, Stony Brook, and Jordan Brook watersheds, southeastern Connecticut.

5. Description of the applications of deicing materials to State-operated roads during winter storms and deicing activities within the Four Mile River, Oil Mill Brook, Stony Brook, and Jordan Brook watersheds, southeastern Connecticut, for the 2008-11 winter seasons

6. Deicing materials applied to town roads during the 2008-11 winter seasons, southeastern Connecticut.

7. Parameter estimates and coefficients of determination for explanatory variables determined for chloride concentrations and loads, at monitoring sites upstream and downstream from Interstate 95, southeastern Connecticut

8. Results of the Kruskal-Wallis rank sum test, and Tukey's honest significance difference test for peak specific conductance, chloride from road deicers, and winter storm and watershed characteristics in the Four Mile River, Oil Mill Brook, Stony Brook, and Jordan Brook watersheds in Connecticut

9. Summary statistics for specific conductance and chloride concentrations for continuous data, and grab samples at the eight monitoring sites, southeastern Connecticut, November 2008-September 2011.

10. Storm characteristics, weather data, and peak chloride concentrations and loads related to deicing and melting events for upstream and downstream monitoring sites at Four Mile River, Oil Mill Brook, Stony Brook, and Jordan Brook, southeastern Connecticut, November 2008-September 2011

11. Estimated mean chloride loads and yields at the four monitoring sites downstream from Interstate 95, and chloride loads in streams, atmospheric deposition, and deicers applied to town and State roads and parking lots in the study areas of Four Mile River, Oil Mill Brook, Stony Brook, and Jordan Brook watersheds, southeastern Connecticut, November 2008-September 2011

12. Watershed and deicing event characteristics that affect specific conductance and chloride concentrations during winter deicing events.

13. Multiple linear regression estimates of model coefficients and standard errors, $t$-statistics, and $p$-values for the dependent variable natural log of peak specific conductance during winter storms for the Four Mile River, Oil Mill Brook, Stony Brook, and Jordan Brook watersheds, southeastern Connecticut, November 2008-September 2011 


\section{Conversion Factors}

Inch/Pound to International System of Units

\begin{tabular}{|c|c|c|}
\hline Multiply & By & To obtain \\
\hline \multicolumn{3}{|c|}{ Length } \\
\hline inch (in.) & 2.54 & centimeter $(\mathrm{cm})$ \\
\hline inch (in.) & 25.4 & millimeter $(\mathrm{mm})$ \\
\hline foot $(\mathrm{ft})$ & 0.3048 & meter $(\mathrm{m})$ \\
\hline mile (mi) & 1.609 & kilometer (km) \\
\hline \multicolumn{3}{|c|}{ Area } \\
\hline square mile $\left(\mathrm{mi}^{2}\right)$ & 2.590 & square kilometer $\left(\mathrm{km}^{2}\right)$ \\
\hline \multicolumn{3}{|c|}{ Volume } \\
\hline gallon (gal) & 3.785 & liter (L) \\
\hline gallon (gal) & 0.003785 & cubic meter $\left(\mathrm{m}^{3}\right)$ \\
\hline \multicolumn{3}{|c|}{ Flow rate } \\
\hline cubic foot per second $\left(\mathrm{ft}^{3} / \mathrm{s}\right)$ & 0.02832 & cubic meter per second $\left(\mathrm{m}^{3} / \mathrm{s}\right)$ \\
\hline $\begin{array}{l}\text { cubic foot per second per square } \\
\text { mile }\left[\left(\mathrm{ft}^{3} / \mathrm{s}\right) / \mathrm{mi}^{2}\right]\end{array}$ & 0.01093 & $\begin{array}{l}\text { cubic meter per second per } \\
\text { square kilometer }\left[\left(\mathrm{m}^{3} / \mathrm{s}\right) / \mathrm{km}^{2}\right]\end{array}$ \\
\hline inch per year (in/yr) & 25.4 & millimeter per year (mm/yr) \\
\hline \multicolumn{3}{|c|}{ Mass } \\
\hline pound, avoirdupois (lb) & 0.4536 & kilogram (kg) \\
\hline ton, short $(2,000 \mathrm{lb})$ & 0.9072 & megagram (Mg) \\
\hline ton per day (ton/d) & 0.9072 & metric ton per day \\
\hline ton per day (ton/d) & 0.9072 & megagram per day (Mg/d) \\
\hline $\begin{array}{l}\text { ton per day per square mile } \\
{\left[(\text { ton } / \mathrm{d}) / \mathrm{mi}^{2}\right]}\end{array}$ & 0.3503 & $\begin{array}{l}\text { megagram per day per square } \\
\text { kilometer }\left[(\mathrm{Mg} / \mathrm{d}) / \mathrm{km}^{2}\right]\end{array}$ \\
\hline
\end{tabular}

Temperature in degrees Celsius $\left({ }^{\circ} \mathrm{C}\right)$ may be converted to degrees Fahrenheit $\left({ }^{\circ} \mathrm{F}\right)$ as ${ }^{\circ} \mathrm{F}=\left(1.8 \times{ }^{\circ} \mathrm{C}\right)+32$.

\section{Datum}

Vertical coordinate information is referenced to the North American Vertical Datum of 1988 (NAVD 88).

Horizontal coordinate information is referenced to the North American Datum of 1983 (NAD 83).

Altitude, as used in this report, refers to distance above the vertical datum. 


\section{Supplemental Information}

Specific conductance is given in microsiemens per centimeter at 25 degrees Celsius $\left(\mu \mathrm{S} / \mathrm{cm}\right.$ at $\left.25^{\circ} \mathrm{C}\right)$.

Concentrations of chemical constituents in water are given in milligrams per liter (mg/L), unless otherwise noted.

\section{Abbreviations}

$\begin{array}{ll}\text { AMLE } & \text { adjusted maximum likelihood estimation } \\ \text { CLEAR } & \text { Center for Land Use Education and Research } \\ \text { ConnDOT } & \text { Connecticut Department of Transportation } \\ \text { CTDEEP } & \text { Connecticut Department of Energy and Environmental Protection } \\ \text { EPA } & \text { U.S. Environmental Protection Agency } \\ \text { FHWA } & \text { Federal Highway Administration } \\ \text { GIS } & \text { geographic information system } \\ \text { HSD } & \text { honest significance difference } \\ \text { I-95 } & \text { Interstate 95 } \\ \text { ISAT } & \text { Impervious Surface Analysis Tool } \\ \text { KGON } & \text { Groton-New London airport weather station } \\ \text { MADIS } & \text { Meteorological Assimilation Data Ingest System } \\ \text { MLE } & \text { maximum likelihood estimation } \\ \text { NADP } & \text { National Atmospheric Deposition Program } \\ \text { NLCD } & \text { National Land Cover Dataset } \\ \text { NWIS } & \text { National Water Information System } \\ \text { SMCL } & \text { secondary maximum contaminant level } \\ \text { USGS } & \text { U.S. Geological Survey }\end{array}$




\title{
Chloride Concentrations, Loads, and Yields in Four Watersheds Along Interstate 95, Southeastern Connecticut, 2008-11-Factors That Affect Peak Chloride Concentrations During Winter Storms
}

\author{
By Craig J. Brown, John R. Mullaney, Jonathan Morrison, Joseph W. Martin, and Thomas J. Trombley
}

\section{Abstract}

Chloride $\left(\mathrm{Cl}^{-}\right)$concentrations and loads and other water chemistry characteristics were assessed to evaluate potential effects of road-deicer applications on streamwater quality in four watersheds along Interstate 95 (I-95) in southeastern Connecticut from November 1, 2008, through September 30, 2011. Streamflow and water quality were studied in the Four Mile River, Oil Mill Brook, Stony Brook, and Jordan Brook watersheds, where developed land ranged from 9 to 32 percent. Water-quality samples were collected and specific conductance was measured continuously at paired waterquality monitoring sites, upstream and downstream from I-95. Specific conductance values were related to $\mathrm{Cl}^{-}$concentrations to assist in determining the effects of road-deicing operations on the levels of $\mathrm{Cl}^{-}$in the streams. Streamflow and water-quality data were compared with weather data and with the timing, amount, and composition of deicers applied to State highways. Grab samples were collected during winter stormwater-runoff events, such as winter storms or periods of rain or warm temperatures in which melting takes place. Grab samples were also collected periodically during the spring and summer and during base-flow conditions.

The estimated $\mathrm{Cl}^{-}$concentrations at the eight waterquality monitoring sites during winter storms peaked as high as 270 milligrams per liter $(\mathrm{mg} / \mathrm{L})$ and were well below the U.S. Environmental Protection Agency (EPA) recommended acute chloride toxicity criterion of $860 \mathrm{mg} / \mathrm{L}$ and the chronic 4-day average toxicity criterion of $230 \mathrm{mg} / \mathrm{L}$. $\mathrm{Cl}^{-}$concentrations in streams, particularly at sites downstream from I-95, peaked during increased streamflow in the winter and early spring as a result of deicers applied to roads and washed off by stormwater or meltwater. $\mathrm{Cl}^{-}$concentrations during most of the nonwinter seasons decreased during increases in streamflow because storm runoff was more dilute than base flow. However, peaks in specific conductance and estimated chloride concentrations at streams in more urbanized watersheds corresponded to peaks in streamflow well after winter snow or ice events; these delayed peaks in $\mathrm{Cl}^{-}$concentration likely resulted from deicer residue that remained in melting snow piles and on roadsides and (or) that were flushed from soils and shallow groundwater, then discharged downstream.
Estimated peak $\mathrm{Cl}^{-}$concentrations varied with the type of winter storm event and were highest during or after winter storms of frozen precipitation and rain, in which the rain or meltwater effectively washed off the deicers. Estimated peak $\mathrm{Cl}^{-}$concentrations correlated positively with the duration of deicer application but generally not with streamflow. Estimated peak $\mathrm{Cl}^{-}$concentrations during the winter season were highest during low streamflow at most sites.

Chloride concentrations varied considerably in shallow groundwater as a result of land-use differences. $\mathrm{Cl}^{-}$concentrations were very high (as high as $800 \mathrm{mg} / \mathrm{L}$ ) in shallow groundwater downstream from I-95 at the Four Mile River site. Chloride/bromide mass concentration ratios and the proximity of a former landfill and sewage lagoon upstream indicate a likely source of $\mathrm{Cl}^{-}$is landfill leachate and possibly sewage leachate.

$\mathrm{Cl}^{-}$loads in streams generally were highest in the winter and early spring. The estimated daily $\mathrm{Cl}^{-}$yield for the four monitoring sites downstream from I-95 ranged from 0.0004 ton per day per square mile for one of the least developed watersheds to 0.052 ton per day per square mile for the watershed with the highest percentage of urban development and impervious area. The estimated median contribution of $\mathrm{Cl}^{-}$load from atmospheric deposition was small and ranged from 0.07 percent of $\mathrm{Cl}^{-}$load at the Jordan Brook watershed to 0.57 percent at the Oil Mill Brook watershed. The $\mathrm{Cl}^{-}$loads in streams (outputs) were compared with $\mathrm{Cl}^{-}$load inputs, which include atmospheric deposition and deicer applications; $\mathrm{Cl}^{-}$ load inputs were slightly larger than the $\mathrm{Cl}^{-}$load outputs at most of the sites during most years but do not account for the $\mathrm{Cl}^{-}$load in groundwater leaving the watersheds.

A multiple linear regression model was developed to describe the variability of the natural log of peak specific conductance, as well as estimated $\mathrm{Cl}^{-}$concentrations. Five significant variables best explained the variability in the natural log of the peak specific conductance after deicing events: (1) snow on ground before deicing event; (2) winter precipitation with rain; (3) specific conductance in base flow; (4) State-operated road lane miles divided by watershed area; and (5) amount of $\mathrm{Cl}^{-}$from deicers applied to State-operated roads per lane mile. In this report, winter precipitation is defined as any type of precipitation, including frozen precipitation and rain, that 
occurs during the active deicing season, typically November through March. Frozen precipitation is defined here as snow, sleet, freezing rain, or any winter precipitation except rain.

The addition of a lane mile in both directions on I-95 would result in an estimate of approximately 2 to 11 percent increase in $\mathrm{Cl}^{-}$input from deicers applied to I-95 and other roads maintained by Connecticut Department of Transportation. The largest estimated increase in $\mathrm{Cl}^{-}$load was in the watersheds with the greatest number miles of I-95 corridor relative to the total lane miles maintained by Connecticut Department of Transportation. On the basis of these estimates and the estimated peak $\mathrm{Cl}^{-}$concentrations during the study period, it is unlikely that the increased use of deicers on the additional lanes would lead to $\mathrm{Cl}^{-}$concentrations that exceed the aquatic habitat criteria.

\section{Introduction}

Urbanization and the associated construction or expansion of roads, highways, and parking lots typically lead to an increased use of road deicers in the northern United States (Bubeck and others, 1971; Wulkowicz and Saleem, 1974; Granato and others, 1995; Mullaney and others, 2009; Cassanelli and Robbins, 2013). A primary concern regarding road deicing is the degradation of surface water and groundwater that may be used for aquatic habitat (Williams and others, 1999; Corsi and others, 2010; Trowbridge and others, 2010) or for drinking-water supply (Ostendorf and others, 2006; Heath and Belaval, 2013). The dominant road deicers include sodium chloride $(\mathrm{NaCl})$, calcium chloride $\left(\mathrm{CaCl}_{2}\right)$, and magnesium chloride $\left(\mathrm{MgCl}_{2}\right)$ and dissolve to form ions including chloride $\left(\mathrm{Cl}^{-}\right)$, sodium $\left(\mathrm{Na}^{+}\right)$, and calcium $\left(\mathrm{Ca}^{2+}\right)$. Widespread upward trends in $\mathrm{Cl}^{-}$concentrations in streams have been reported nationwide and may be related to a variety of factors, including increased road area and consequent deicing, increased wastewater and septicsystem discharges, livestock waste and fertilizers, and leachate from landfills and salt-storage areas (Smith and others, 1987; Mullaney and others, 2009; Katz and others, 2011). Similar trends have been reported in Connecticut from the 1970s to 1990s (Trench, 1996; Colombo and Trench, 2002). Elevated concentrations of $\mathrm{Cl}^{-}$and $\mathrm{Na}^{+}$in glacial aquifers in Connecticut have been related to urban land use (Grady, 1993; Grady and Mullaney, 1998). Concentrations of $\mathrm{Cl}^{-}$in Connecticut groundwater are spatially coincident with major roadways and exceed the regulatory maximum contaminant level of 250 milligrams per liter $(\mathrm{mg} / \mathrm{L})$ in some areas (Cassanelli and Robbins, 2013). Potential adverse effects of deicing products, which contain $\mathrm{Cl}^{-}$, on water resources are addressed in Ramakrishna and Viraraghavan (2005), Kaushal and others (2005), and Kelly and others (2010).

The U.S. Environmental Protection Agency (EPA) recommended chronic criterion for aquatic life is a 4-day average $\mathrm{Cl}^{-}$concentration of $230 \mathrm{mg} / \mathrm{L}$, and the recommended acute (1-hour average) criterion concentration for
$\mathrm{Cl}^{-}$is $860 \mathrm{mg} / \mathrm{L}$ (U.S. Environmental Protection Agency, 1988). These criteria relate to a recurrence of no more than once in 3 years. The Connecticut Department of Energy and Environmental Protection (CTDEEP) has recently adopted standards for aquatic-life criteria for $\mathrm{Cl}^{-}$that are identical to the EPA standards (Connecticut Department of Environmental Protection, 2009). The EPA has established a nonenforceable secondary maximum contaminant level (SMCL) of $250 \mathrm{mg} / \mathrm{L}$ for $\mathrm{Cl}^{-}$(for potential cosmetic or aesthetic effects) and a nonregulatory drinking-water advisory concentration of $20 \mathrm{mg} / \mathrm{L}$ for sodium $\mathrm{Na}^{+}$, for individuals on a 500-milligram-per-day Na-restricted diet (U.S. Environmental Protection Agency, 2011).

Effects of road deicers on water quality can be monitored effectively through continuous records of specific conductance, together with periodic streamflow sampling and analysis and continuous estimates of streamflow (Gurnell and others, 1994; Granato and Smith, 1999; Brown and others, 2011). Additional knowledge of the use of road salt (sodium chloride $[\mathrm{NaCl}]$ and other deicing agents), including the timing, amount, and composition of deicers applied to roadways, as well as the weather details, is beneficial in understanding the effects of road-salt washoff on concentrations and loads of $\mathrm{Cl}^{-}$in streamflow (Brown and others, 2011; Granato, 2013). Collection of data to determine the $\mathrm{Cl}^{-}$concentrations and streamflow, and how they affect specific conductance, is important to the development of a regression model to estimate $\mathrm{Cl}^{-}$concentrations.

The Federal Highway Administration (FHWA) and the Connecticut Department of Transportation (ConnDOT) are considering the possible expansion of a 15-mile (mi) stretch of Interstate 95 (I-95) between Old Lyme and New London, Connecticut. Concerns have been raised about the effects of highway expansion on the water quality and biological resources associated with streams crossed by I-95. In 2008, the U.S. Geological Survey (USGS), in cooperation with the FHWA and ConnDOT, began a 3-year study to assess the water quality of streams and the effects of deicing of roads on streamwater quality. Data were collected from November 2008 through September 2011 to provide a better understanding of the water-quality implications of an I-95 expansion and to assist in development of low-impact design alternatives.

\section{Purpose and Scope}

This report describes the collection and analysis of geologic, hydrologic, and water-quality data to assess baseline water-quality conditions along the I-95 corridor during 2008-11. This report also describes the sampling sites in detail, the collection of water stage and streamflow data, water-quality monitoring and sampling, and estimation of $\mathrm{Cl}^{-}$loads and yields. Concentrations of waterquality constituents in samples collected from four streams and two piezometers are presented, and comparisons are made between the chemical quality of streamwater and 
groundwater. Concentrations of $\mathrm{Cl}^{-}$and other chemical constituents and specific conductance are presented in tables and appendixes. Estimates of $\mathrm{Cl}^{-}$loads in streamflow and from atmospheric deposition are presented in figures, and loads from atmospheric deposition are presented in tables. All these data were used to assess how stream and shallow groundwater quality respond to winter storm deicing, deicing amounts, water-quality differences between upstream and downstream sites and between watersheds, and whether $\mathrm{Cl}^{-}$ concentrations exceeded recommended water-quality criteria for protection of aquatic life in watersheds that are typical of those in many parts of Connecticut. The data and analysis in this report supersede those in the interim report (Brown and others, 2011).

\section{Description of Study Area}

The study area encompasses four watersheds in southeastern Connecticut crossed by I-95-Four Mile River, Oil Mill Brook, Stony Brook, and Jordan Brook (fig. 1). The watersheds encompass parts of the towns of Lyme, Old Lyme, East Lyme, Montville, and Waterford, Conn. Two sites in each watershed were selected for sample collection and waterquality monitoring - one upstream and one downstream from I-95 - in order to evaluate the effects of highway deicers on streamwater quality (fig. 1). Streamgages are located at the downstream sites.

Constituent concentrations in streamwater and groundwater are affected by physical watershed characteristics, such as watershed area, groundwater discharge, and precipitation, as well as by chemical sources, such as atmospheric deposition, geology, and land use. Watersheds differ in their ability to collect and conduct water, depending on such factors as size and shape, climate, vegetation, topography, development, and impervious area (Langbein and others, 1947; Granato, 2013). The four watersheds in this study range in size from 1.0 to 5.98 square miles $\left(\mathrm{mi}^{2}\right)$ and are predominantly forested and undeveloped; developed areas range from 9.4 percent at the Four Mile River upstream watershed to 31.5 percent at the Jordan Brook watershed (fig. 2; table 1). ConnDOT data on highway drainage were considered in the delineation of the watershed boundaries (James Spencer, Connecticut Department of Energy and Environmental Protection, written commun., 2012). Data on 2010 land-use and land-cover characteristics (table 1) were determined from LANDSAT Thematic Mapper data, retrieved from the Center for Land Use Education and Research (CLEAR) Web site (University of Connecticut, 2010). The impervious area was estimated by using the Impervious Surface Analysis Tool (ISAT) (Emily Wilson, written commun., University of Connecticut, May 2014, http://www.csc.noaa.gov/digitalcoast/tools/isat) together with the 2010 land-use and land-cover data (table 1).

The study area is underlain by surficial deposits, including Pleistocene glacial stratified deposits, glacial till, and Holocene alluvial deposits, which occur primarily in stream channels (table 2). These deposits are underlain by crystalline rock. Coarse-grained glacial stratified deposits account for 7.7 to 17.8 percent of surficial material in the four watersheds (table 2). Effective recharge to the glacial stratified deposits and groundwater storage and flow within these deposits are much larger than for till deposits (Melvin and Bingham, 1991).

The spatially averaged annual total precipitation in Connecticut over the last 100 years shows a generally upward trend in precipitation with high year-to-year variability. The long-term mean annual precipitation is 44.8 inches per year and is distributed fairly evenly throughout the year (Miller and others, 2002). The average annual precipitation near the coast at the Groton-New London airport (KGON; fig. 1) is 48.7 inches (in.) for a 39-year period of record. Snowfall and other frozen precipitation is a minor component of the total precipitation in Connecticut, particularly along the coast where it is moderated by the ocean. The average snowfall in Connecticut is about 20 to $30 \mathrm{in}$. along the coast, 40 to $60 \mathrm{in}$. inland, and more than 70 in. in the northwestern corner of the State (Miller and others, 2002). The average annual snowfall at Groton, Conn., is $24.6 \mathrm{in}$. with an average winter temperature of - 1.8 degrees Celsius $\left({ }^{\circ} \mathrm{C}\right)$ (National Oceanic and Atmospheric Administration, National Climatic Data Center, n.d.).

Weather data, including daily maximum and minimum air temperature, precipitation amount (fig. $3 A$ ), estimated thickness of snow, and estimated snowmelt (fig. $3 B$ ), were plotted for the study period to help assess the effects of weather on deicers and $\mathrm{Cl}^{-}$concentrations in the watersheds.

\section{Sources of Chloride to Streams and Groundwater in the Study Area}

Sources of $\mathrm{Cl}$ include atmospheric deposition, road deicers, discharge from drinking-water and wastewater-treatment facilities or septic systems, leachate from landfills, and fertilizers. Stormwater runoff from I-95, which is maintained by ConnDOT, was the primary focus of this study, but there are other contributions to streamflow in each watershed, including stormwater runoff from other roadways and impervious areas, interflow, and the groundwater component (base flow). Sources of major ions in base flow include groundwater recharge, road deicers and deicer storage locations, septic-tank drainfields, landfills, fertilizers, and petroleum or chemical spills, as well as aquifer weathering. Potential point sources of $\mathrm{Cl}^{-}$in each watershed were determined from a 1:50,000-scale data layer that includes point locations digitized from Leachate and Wastewater Discharge Source maps compiled by the CTDEEP and point locations digitized on-screen from CTDEEP sources (Connecticut Department of Environmental Protection, 1995). Other sources of salts to freshwater resources include seawater and the natural weathering of bedrock, surficial materials, and soils, or deposits containing halite or saline groundwater (brines). None of the stream sites are tidally affected by seawater, and halite and brines are not present in geologic deposits in this area and, therefore, do not affect stream chemistry in this study. Atmospheric and deicer sources of $\mathrm{Cl}^{-}$are discussed in the following two sections. 


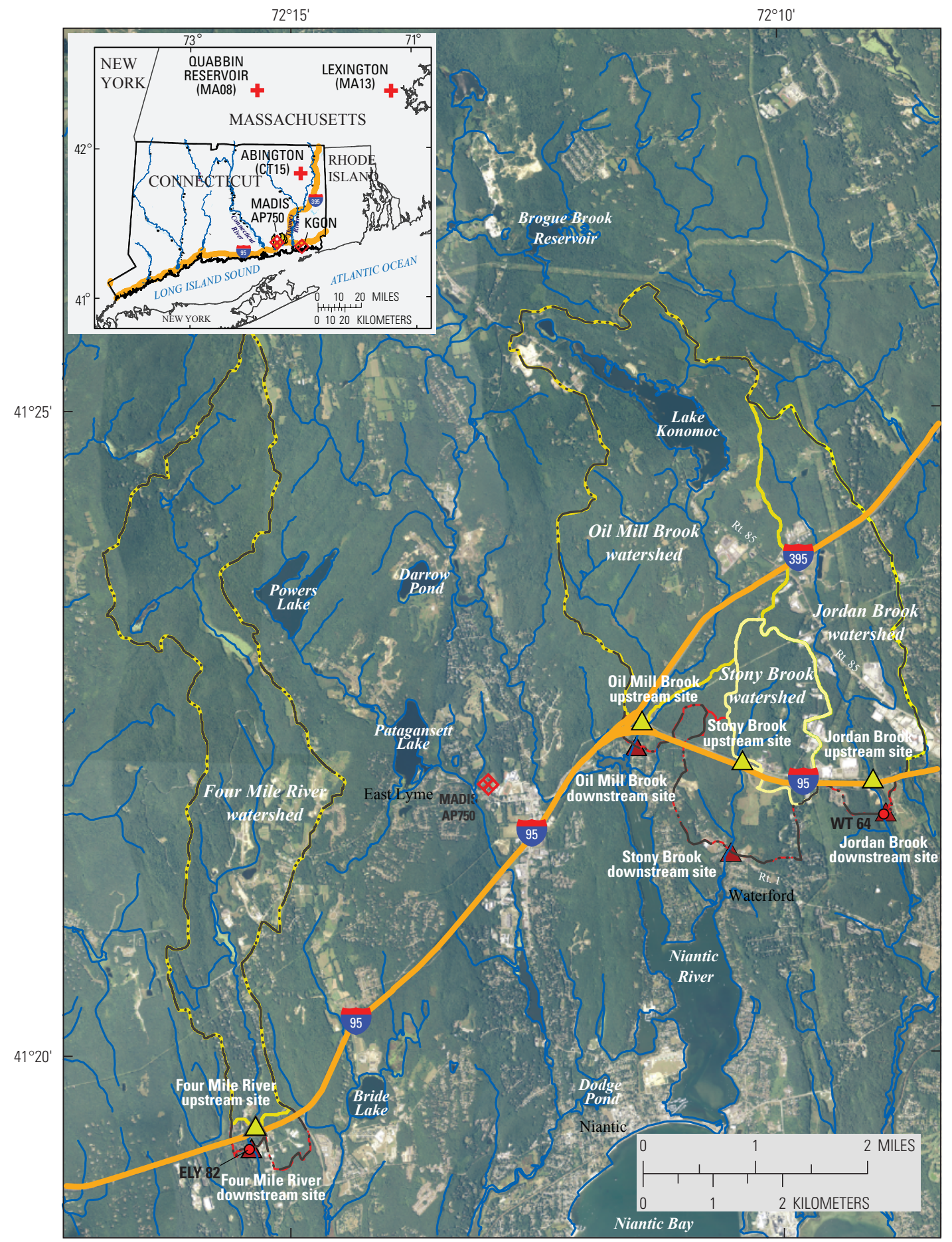

Base from Connecticut Department of Environmental

Protection, 1994, 1:24,000

Projection: Connecticut State Plane Feet

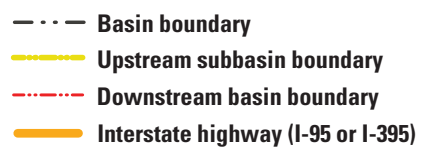

\section{EXPLANATION}

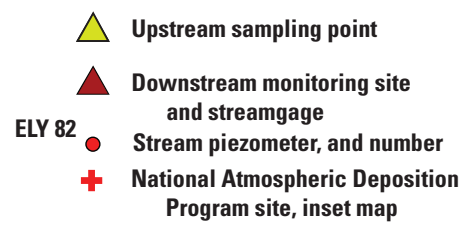

KGON $\diamond$ Weather station, Groton-New London airport, inset map

MADIS Snow observation site, Meteorological Assimilation Data Ingest System (MADIS), inset map and primary map

Figure 1. Location of upstream and downstream water-quality monitoring sites and downstream streamgages on four selected streams along the Interstate 95 corridor study area, southeastern Connecticut, and (inset) location of the Groton-New London airport weather station, a snow observation site, and three National Atmospheric Deposition Program sites. 


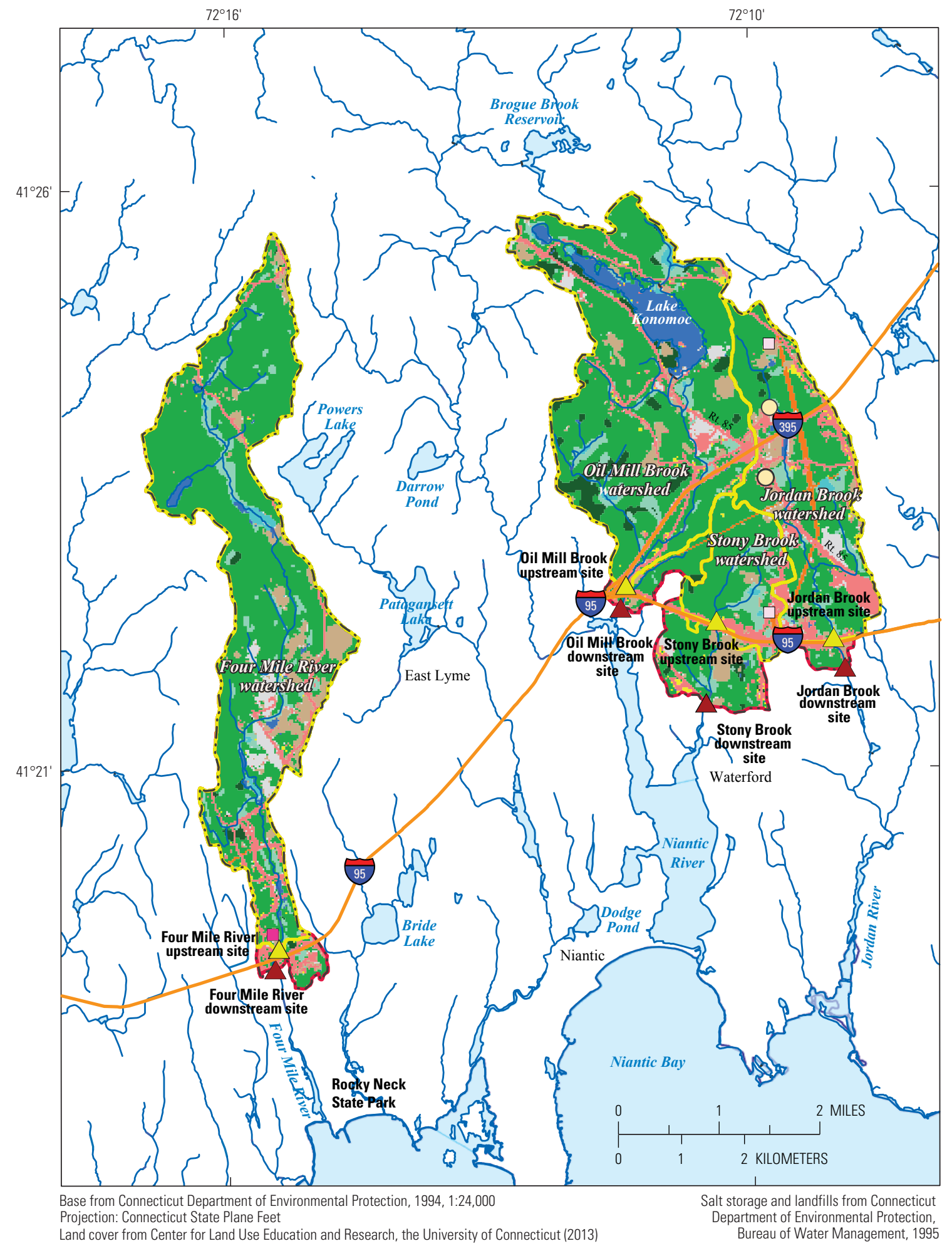

EXPLANATION

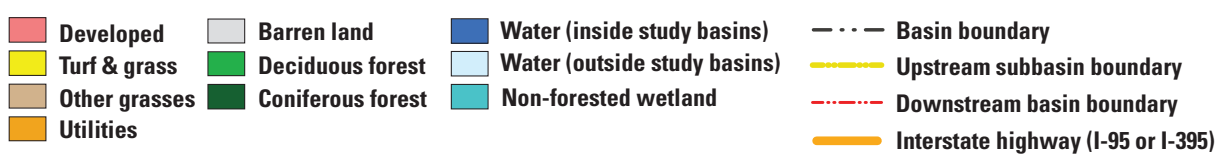

Road salt storage, active

$\triangle$ Upstream monitoring site

$\triangle$ Downstream monitoring site and streamgage

Landfill, active

$\square$ Landfill, inactive

Figure 2. Land cover and water-quality monitoring sites and downstream streamgages, watershed boundaries, locations of deicing salt storage, and landfills in the study areas, southeastern Connecticut. 

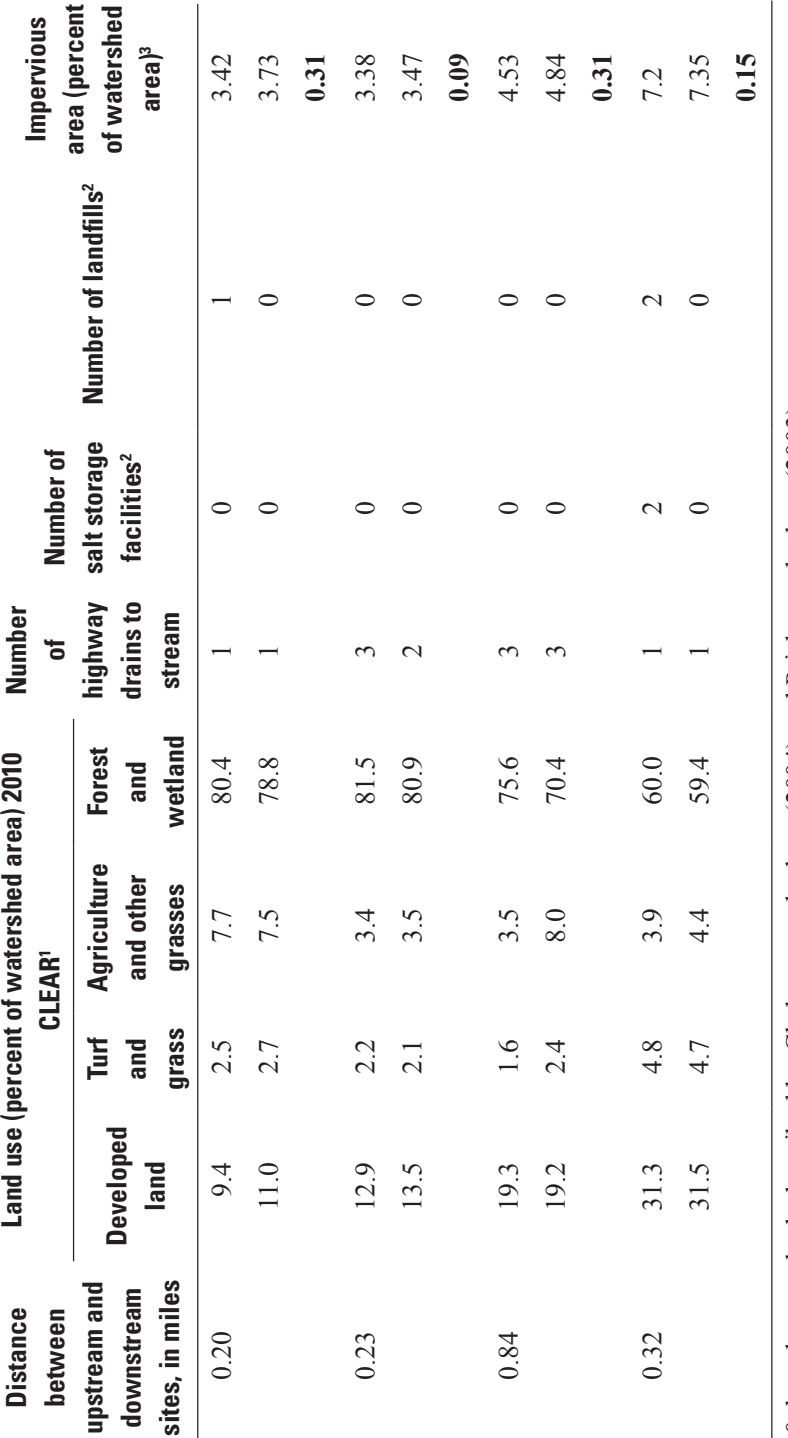

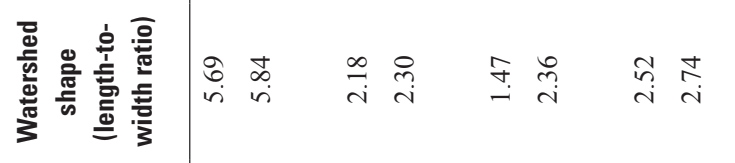

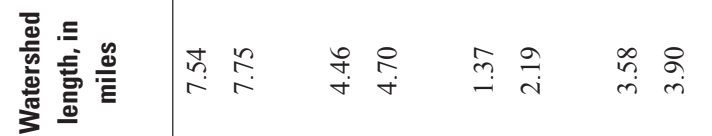

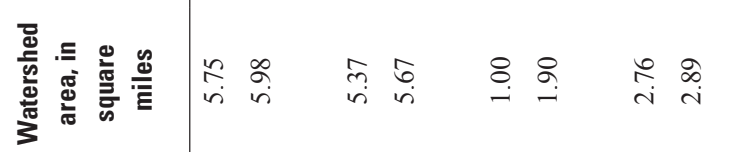

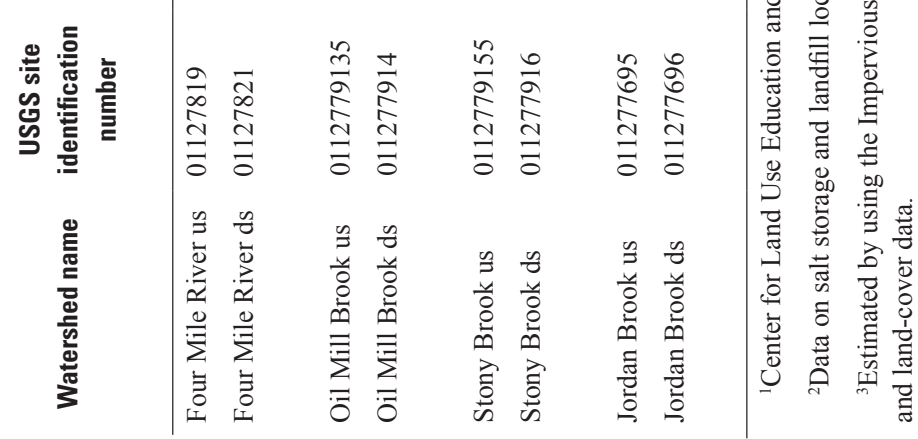


Table 2. Classification of surficial materials for watersheds above each monitoring site in the study area, southeastern Connecticut. [Data from Stone and others (1992). USGS, U.S. Geological Survey]

\begin{tabular}{|c|c|c|c|c|c|c|}
\hline \multirow{2}{*}{ Watershed name } & \multirow{2}{*}{$\begin{array}{c}\text { USGS site } \\
\text { identification } \\
\text { number }\end{array}$} & \multicolumn{5}{|c|}{ Surficial material, in percent of watershed area } \\
\hline & & Coarse grained & Swamp or fines & Till & Thick till & Water \\
\hline Four Mile River upstream & 01127819 & 16.4 & 1.6 & 73.7 & 7.5 & 0.9 \\
\hline Four Mile River downstream & 01127821 & 16.2 & 1.4 & 73.4 & 8.1 & 0.9 \\
\hline Oil Mill Brook upstream & 0112779135 & 13.3 & 1.6 & 71.6 & 4.7 & 8.8 \\
\hline Stony Brook upstream & 0112779155 & 7.7 & 13.9 & 78.4 & 0 & 0 \\
\hline Stony Brook downstream & 011277916 & 17.8 & 7.7 & 74.5 & 0 & 0 \\
\hline
\end{tabular}
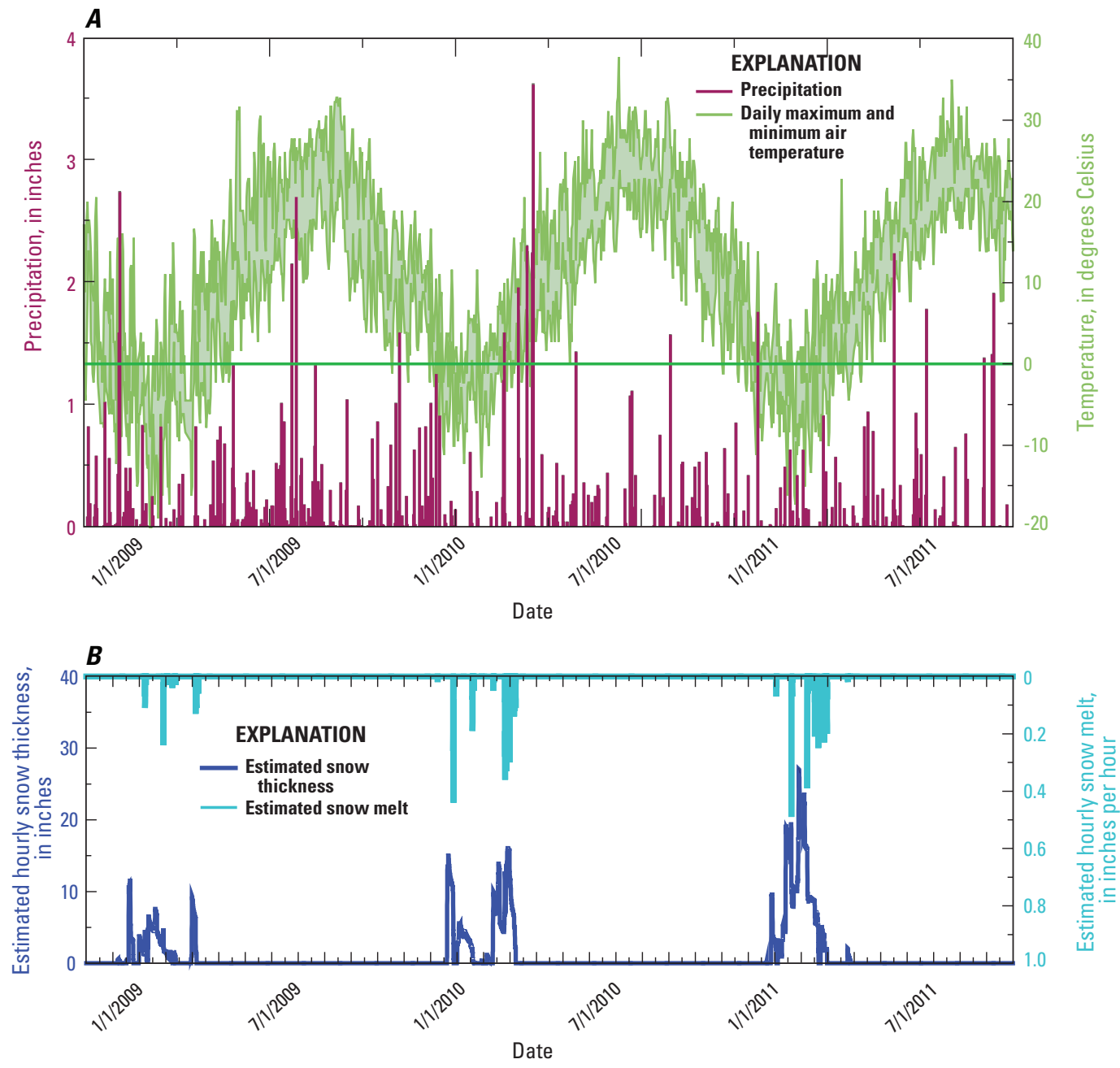

Figure 3. A, Daily maximum and minimum air temperature and continuous precipitation at the GrotonNew London airport weather station (KGON), and $B$, estimated hourly snow thickness and snowmelt at a snow observation station (MADIS AP760) in southeastern Connecticut, from November 2008 to September 2011. 
Chloride Concentrations, Loads, and Yields in Four Watersheds Along Interstate 95, Southeastern Connecticut

\section{Atmospheric Deposition}

Atmospheric deposition generally transmits salts from both anthropogenic and natural sources to watersheds and groundwater. Atmospheric deposition of major ions is more concentrated in coastal areas than in inland areas (Gay and Melching, 1995). Cl- load in precipitation can be a substantial part of the total $\mathrm{Cl}^{-}$load in relatively undeveloped areas, particularly in coastal areas (Mullaney and others, 2009; National Atmospheric Deposition Program, 2012). National Atmospheric Deposition Program (NADP) wet deposition stations in southeastern New England provide concentration data that can be used to estimate atmospheric deposition yields and loads (fig. 1; table 3).

\section{Road Deicing Chemicals and Their Application in the Study Area}

Road-deicing chemicals are a primary source of $\mathrm{Cl}^{-}$and other constituents to water resources near highways or other impervious areas in the northern United States (Bubeck and others, 1971; Mullaney and others, 2009; Wulkowicz and Saleem, 1974). The use of $\mathrm{NaCl}$ in the United States increased from 42.9 million tons in 1975 to nearly 58.5 million tons in 2005 (Kostick and others, 2007). The application of $\mathrm{NaCl}$ to roads is now the largest use of salt in the United States (Kostick and others, 2007), and during 2009, 2010, and 2011, road application represented about 39 percent, 43 percent, and 38 percent, respectively, of the end use of salt (U.S. Geological Survey, 2015).

During the past decade (2000-2009), deicing of State roads throughout New England and other northern States has changed from simply plowing, salting, and sanding to pretreating by spraying liquids that prevent snow and ice from bonding with the road (anti-icing) and using less sand. Typical $\mathrm{NaCl}$ application rates for New England States ranged from 240 to 300 pounds per lane mile (Massachusetts Department of Transportation, 2012); the State of Connecticut applied about 200 pounds per lane mile (Connecticut Department of Transportation, 2013). Under field conditions, $\mathrm{NaCl}$ lowers the freezing point of water to $-9{ }^{\circ} \mathrm{C}$; other salts, such as $\mathrm{CaCl}_{2}$, depress the freezing point further (to $-29^{\circ} \mathrm{C}$ ), but these are more expensive (Connecticut Department of Transportation, 2009). $\mathrm{NaCl}$ brine, therefore, is generally applied to State bridges, ramps, overpasses, and some roads before snow or ice events.

The primary road deicers used by the ConnDOT include $\mathrm{NaCl}$ (in both the liquid brine and solid halite forms) and $\mathrm{CaCl}_{2}$ liquid (Connecticut Department of Transportation, 2009); deicers used by the towns include $\mathrm{NaCl}$ (halite) and a product that contains magnesium chloride $\left(\mathrm{MgCl}_{2}\right)$ together with distillers condensed solubles. ${ }^{1}$ ConnDOT initiated a new snow and ice removal program beginning in the 2006-7 winter season (Connecticut Department of Transportation, 2009). ConnDOT crews generally avoid using sand on roadways because it provides only temporary traction, fouls waterways and the air, clogs drains, and is costly to clean up (Connecticut Department of Transportation, 2009). The primary purpose of the new program is to reduce the use of sand and improve winter driving conditions by (1) pretreating pavements with $\mathrm{NaCl}$ brine, thus preventing bonding of snow or ice, and (2) using liquid $\mathrm{CaCl}_{2}$ as a wetting agent for rock salt (halite), which is applied during snow or ice events to lower the freezing point of water, to reduce bounce and scatter, and to reduce the melting time.

For pretreatment, ConnDOT uses a 23-percent $\mathrm{NaCl}$ brine solution for anti-icing at a rate of about 30 gallons per lane mile. Larger rates ( 40 gallons per lane mile) of the $\mathrm{NaCl}$ brine solution are applied at pavement temperatures below $-1{ }^{\circ} \mathrm{C}$, but none is applied below $-5.5^{\circ} \mathrm{C}$ because it is ineffective at colder temperatures. The brine solution is applied to bridges and selected roadways by a tanker truck using spray bars with nozzles that are spaced about $10 \mathrm{in}$. apart. The brine solution is applied up to 5 days before an anticipated precipitation event and leaves 2-in. strips that melt frozen precipitation on contact.

$\mathrm{CaCl}_{2}$ in liquid form (about 32 percent by weight) has been used as a wetting agent on Connecticut State roads since the winter of 2006-7. It is sprayed onto halite rock salt in the spreader chute on plows and other snow-removal equipment. The $\mathrm{CaCl}_{2}$ brine-halite combination melts snow or ice faster during application than halite without brine and sand. The typical mixing rate is 10 gallons of liquid $\mathrm{CaCl}_{2}$ per ton of rock salt, but the rates vary depending on temperature, humidity, type and timing of storms, and traffic conditions (Connecticut Department of Transportation, 2009). In some situations where ice has already formed, liquid ice-control chemicals $\left(\mathrm{CaCl}_{2}\right.$ or $\mathrm{NaCl}$ brine) are applied directly to the pavement.

The types and lengths of State roads maintained by ConnDOT (table 4) and the times and duration of application for each winter storm or deicing activity were used together with the deicer type and rates of application to estimate the amounts of deicers applied within each watershed (table 5). Typical spreading rates from trucks with calibrated spreaders are about 200 pounds per lane mile, \pm 20 percent (Connecticut Department of Transportation, 2009). The total amount of deicers applied to the highways varied from storm to storm and year to year (table 5). The deicers applied to I-95 and other State roads for the 2008-11 winter season were categorized by (1) storms, which refers to snow or ice storm events, and (2) activities, such as icy conditions or drifting snow, which generally require shorter periods of deicing (table 5; Connecticut Department of Transportation, 2009).

\footnotetext{
${ }^{1}$ Fermentation byproducts, which include spent yeast cells and other nutrients that remain after corn grain has been fermented to produce ethanol; known in the food industry as "corn syrup."
} 


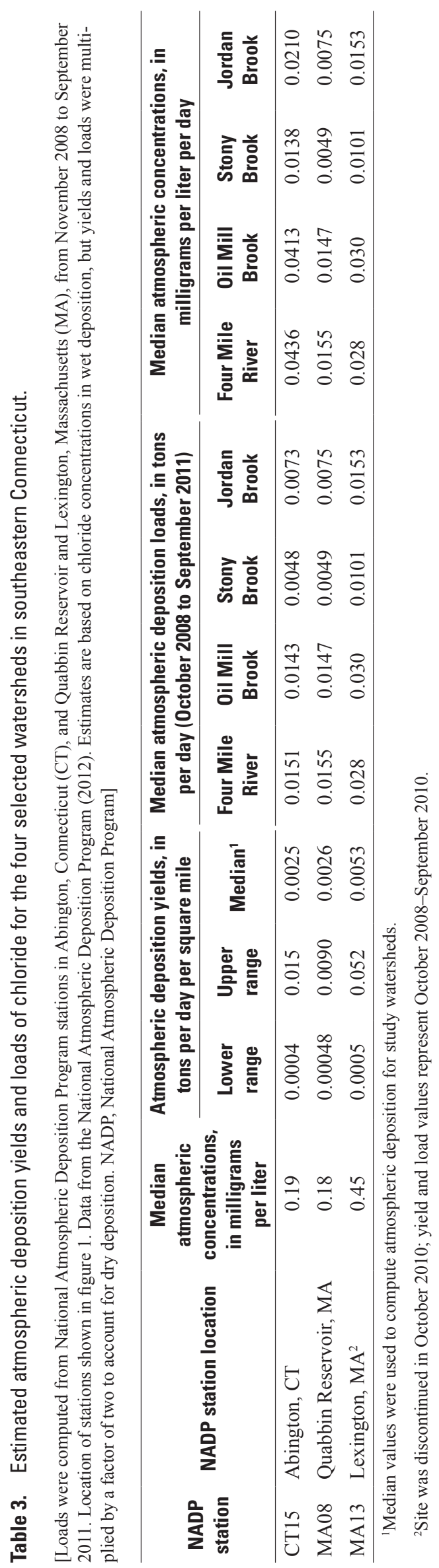




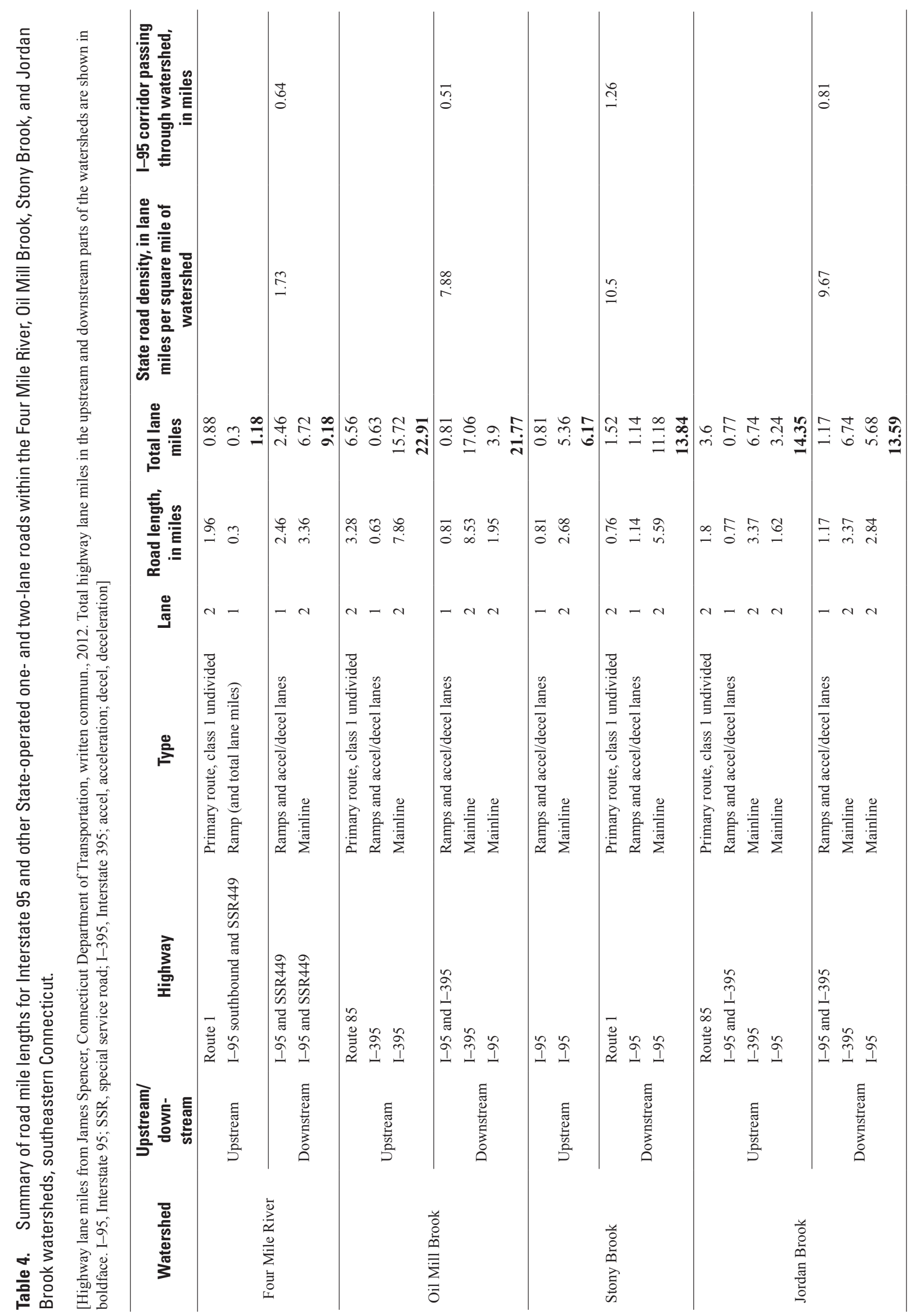


Table 5. Description of the applications of deicing materials to State-operated roads during winter storms and deicing activities within the Four Mile River, Oil Mill Brook, Stony Brook, and Jordan Brook watersheds, southeastern Connecticut, for the 2008-11 winter seasons.

[Available separately at http://dx.doi.org/10.3133/sir20155057]

The town road lengths and the annual deicer application amounts were obtained from town public works departments (table 6). Deicers included $\mathrm{NaCl}$ (halite), a salt and sand mixture, and (or) Ice B'Gone ${ }^{\circledR}$. Ice B'Gone ${ }^{\circledR}$ is a deicing product that contains $\mathrm{MgCl}_{2}$ together with distillers condensed solubles and was used in the towns of East Lyme, Waterford, and Montville. The mixture is described as having a synergistic melting effect that results in a melting temperature of $-31{ }^{\circ} \mathrm{C}$ (Sears Ecological Applications Co., LLC, 2009). The lengths of town roads within each watershed and the proportions of annual deicer load were used to determine the annual deicer load applied to town roads for each watershed.

The towns of East Lyme and Old Lyme used halite, salt and sand mixture, and (or) Ice B'Gone ${ }^{\circledR}$ to treat snow and ice on town roads; during the 2008-11 winter seasons these towns applied 0.6 to 5.5 tons of $\mathrm{Cl}^{-}$per road mile within the Four
Mile River watershed (table 6; M.A. Giannattasio, Town of East Lyme, oral commun., 2011; E.C. Adanti, Town of Old Lyme, oral commun., 2011). The Oil Mill Brook watershed includes the towns of Montville, which applied a combination of halite and Ice B'Gone ${ }^{\circledR}$ (D.W. Bordeau, Town of Montville, oral commun., 2011), and Waterford, which applied only Ice B'Gone ${ }^{\circledR}$. Together, these towns applied road salt at rates of 59.3 to 119 tons of $\mathrm{Cl}^{-}$per road mile during the winter seasons of 2008-11. Roads in the Stony Brook and Jordan Brook watersheds, which are both in Waterford, were treated annually with 20.8 tons and 76.6 tons, respectively, during the 2008-11 winter seasons (R.R. Cusano, Town of Waterford, oral commun., 2011).

Road-deicing chemicals applied to parking lots, sidewalks, and driveways also represent an important source of $\mathrm{Cl}^{-}$and other constituents to water. Attempts to obtain deicer application amounts applied to these impervious areas were unsuccessful, so an estimate of 30 percent of deicers applied to roads was used to represent deicers applied to parking lots, sidewalks, and driveways. Harte and Trowbridge (2010) estimated that parking lots made up about 50 percent of salt inputs in watersheds adjacent to Interstate 93 in southern New Hampshire. 
Table 6. Deicing materials applied to town roads during the 2008-11 winter seasons, southeastern Connecticut.

$\left[\mathrm{Cl}^{-}\right.$, chloride; $\mathrm{NaCl}$, sodium chloride; --, none reported]

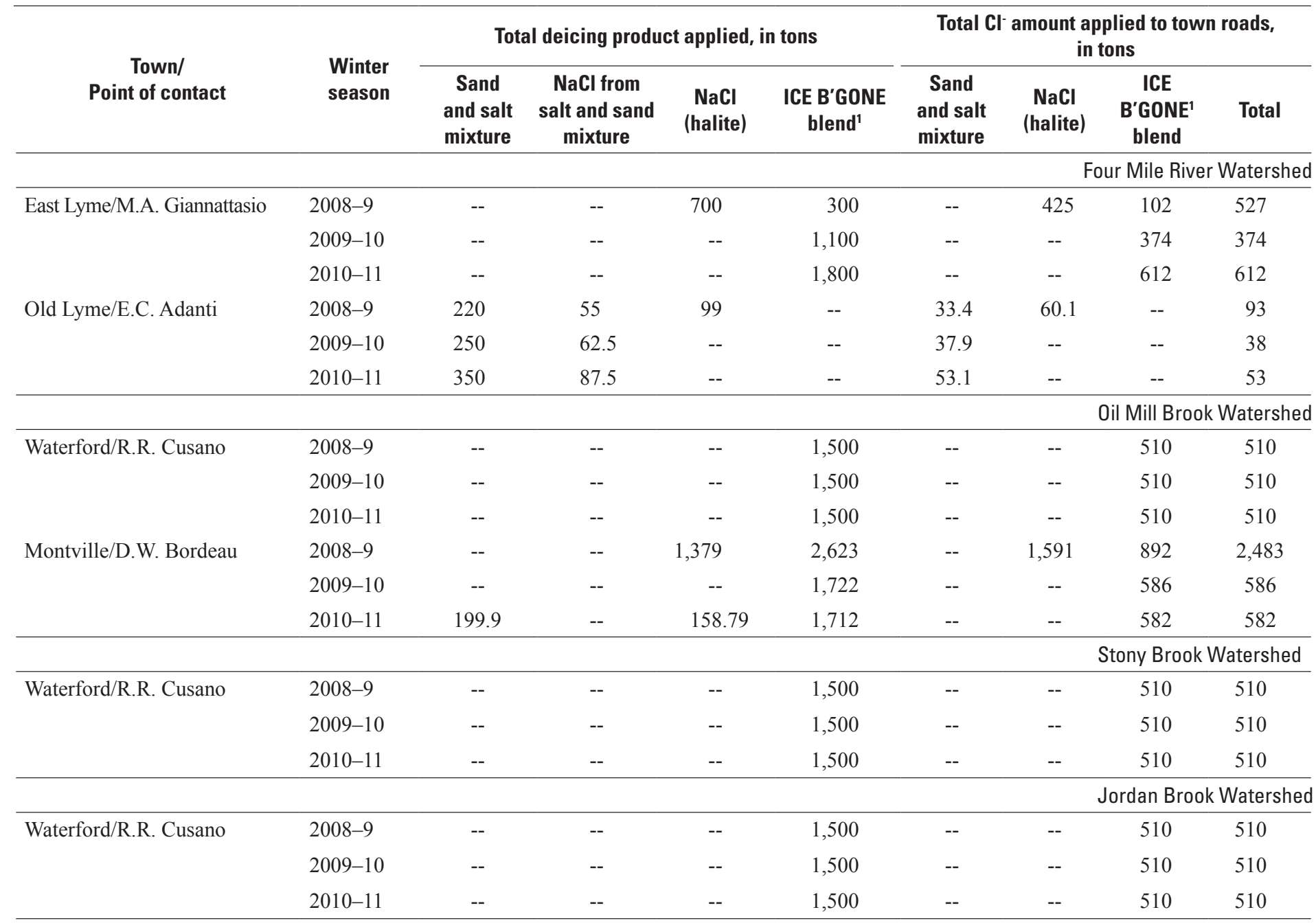

${ }^{1}$ Ice B'Gone blend consists of 14 percent magnesium chloride $\left(\mathrm{MgCl}_{2}\right), 4.2$ percent calcium chloride $\left(\mathrm{CaCl}_{2}\right), 0.3$ percent sodium chloride $(\mathrm{NaCl}), 0.1$ percent potassium chloride $(\mathrm{KCl})$, and 50 percent distillers condensed solubles (by weight) in 8 gallons of solution per ton of $\mathrm{NaCl}$. 


\begin{tabular}{|c|c|c|c|c|c|c|c|c|}
\hline \multirow{2}{*}{$\begin{array}{l}\text { Length } \\
\text { of roads } \\
\text { in town, } \\
\text { in miles }\end{array}$} & \multirow{2}{*}{$\begin{array}{l}\text { Length of } \\
\text { town roads in } \\
\text { watershed, } \\
\text { in miles }\end{array}$} & \multicolumn{4}{|c|}{$\begin{array}{l}\mathrm{Cl}^{-} \text {amount applied to town roads per } \\
\text { watershed, in tons }\end{array}$} & \multirow{2}{*}{$\begin{array}{l}\mathrm{Cl}^{-} \text {rate applied } \\
\text { to town roads in } \\
\text { watershed, } \\
\text { in tons } \\
\text { per lane mile }\end{array}$} & \multicolumn{2}{|c|}{$\begin{array}{l}\mathrm{Cl}^{-} \text {amount applied to town } \\
\text { roads in watershed, in tons }\end{array}$} \\
\hline & & $\begin{array}{l}\text { Sand and } \\
\text { salt mixture }\end{array}$ & $\begin{array}{c}\mathrm{NaCl} \\
\text { (halite) }\end{array}$ & $\begin{array}{l}\text { ICE B'Gone } \\
\text { blend }\end{array}$ & Subtotal & & $\begin{array}{l}\text { Winter } \\
\text { season }\end{array}$ & Total \\
\hline \multirow[t]{3}{*}{112} & 11.9 & -- & 45.1 & 10.84 & 56.0 & 2.35 & $2008-9$ & 59.8 \\
\hline & & -- & -- & 39.7 & 39.7 & 1.67 & & \\
\hline & & -- & -- & 65.0 & 65.0 & 2.73 & $2009-10$ & 41.3 \\
\hline \multirow[t]{3}{*}{60} & 2.5 & 1.39 & 2.5 & -- & 3.9 & 0.778 & & \\
\hline & & 1.58 & -- & -- & 1.6 & 0.316 & 2010-11 & 67.2 \\
\hline & & 2.21 & -- & -- & 2.2 & 0.442 & & \\
\hline \multirow[t]{3}{*}{120} & 9.6 & -- & -- & 40.9 & 40.9 & 2.13 & $2008-9$ & 119 \\
\hline & & -- & -- & 40.9 & 40.9 & 2.13 & & \\
\hline & & -- & -- & 40.9 & 40.9 & 2.13 & 2009-10 & 59.4 \\
\hline \multirow[t]{3}{*}{119} & 3.8 & -- & 50.1 & 28.1 & 78.2 & 10.43 & & \\
\hline & & -- & -- & 18.5 & 18.5 & 2.46 & $2010-11$ & 59.3 \\
\hline & & -- & -- & 18.3 & 18.3 & 2.45 & & \\
\hline \multirow[t]{3}{*}{120} & 4.9 & -- & -- & 20.8 & 20.8 & 2.13 & $2008-9$ & 20.8 \\
\hline & & -- & -- & 20.8 & 20.8 & 2.13 & $2009-10$ & 20.8 \\
\hline & & -- & -- & 20.8 & 20.8 & 2.13 & 2010-11 & 20.8 \\
\hline \multirow[t]{3}{*}{119} & 17.9 & -- & -- & 76.6 & 76.6 & 2.1 & $2008-9$ & 76.6 \\
\hline & & -- & -- & 76.6 & 76.6 & 2.1 & 2009-10 & 76.6 \\
\hline & & -- & -- & 76.6 & 76.6 & 2.1 & $2010-11$ & 76.6 \\
\hline
\end{tabular}




\section{Methods of Data Collection and Analysis}

Streamflow and water-quality data were collected (November 1, 2008, to September 30, 2011) by using methods described below or discussed in Brown and others (2011) to assess weather information, water quality, stream stage, and streamflow for the four selected streams. All water-quality, stream-stage, and streamflow data collected in the study are stored in the USGS National Water Information System (NWIS) database.

\section{Site Selection}

Four streams between the Connecticut River and the Thames River-Four Mile River, Oil Mill Brook, Stony Brook, and Jordan Brook (fig. 1) —were selected for study on the basis of the percentage of land-use types, the percentage of impervious area, road types and density, the presence of coarse glacial stratified deposits, suitability for streamflow and waterquality monitoring, site accessibility, representativeness and transferability, and the absence of estuarine or brackish waters.

\section{Weather Data}

Weather data were collected to assess factors such as temperature and amounts, types, and timing of precipitation, which affect melting and washing of deicers off road surfaces, and subsequent changes in $\mathrm{Cl}^{-}$concentration in streams. Hourly measurements of air temperature and precipitation for the study period were obtained from continuous temperature and daily precipitation data collected at (fig. 1) as part of the National Weather Service Meteorological Assimilation Data Ingest System (MADIS). The data were accessed through Weather Underground (http://www.wunderground.com/).

A branch of the National Weather Service, the National Operational Hydrologic Remote Sensing Center, assembles daily ground-based, airborne, and satellite snow observations for the conterminous United States (National Operational Hydrologic Remote Sensing Center, 2005). These data are used together with estimates of snowpack characteristics determined by a snow model to generate the operational, daily National Oceanic and Atmospheric Administration (NOAA) National Snow Analysis for the United States, for which snow depth, snow-water equivalent, and snowmelt are estimated. The snow observation station (MADIS AP750) nearest the study area is located in southeastern Connecticut at latitude $41.36733^{\circ} \mathrm{N}$, longitude $72.216^{\circ} \mathrm{W}$, at an altitude of 72 feet (ft) above the NAVD 88 (fig. 1).

\section{Streamflow}

Stream stage and streamflow were measured in the four streams at sites downstream from I-95 (fig. 1) and used for computations of $\mathrm{Cl}^{-}$loads in highway stormwater runoff.
Stream stage was recorded at 5-minute intervals with pressure transducers and data loggers, and streamflow measurements were made periodically at these sites. These data were used to develop a rating curve to convert stage measurements into streamflow. The periods of record for gage height and streamflow are shown in appendixes 2-5. Streamflow data at the downstream sites had breaks caused by problems with stage recorders. A high streamflow event in September 2010 caused flooding at Oil Mill Brook downstream site, which changed the channel control features and affected the stage-discharge relation. Stage was too low to determine streamflow at the Stony Brook downstream site during June 21-August 11, 2010, and at the Jordan Brook downstream site during July 28-August 17, 2010. Periods of missing record were estimated by using hydrograph comparisons among adjacent sites. All streamflow records were computed in accordance with standard USGS protocols for computation of streamflow records as described by Rantz and others (1982).

\section{Water Quality}

Water-quality data were collected at sites upstream and downstream from I-95 on the four streams to monitor $\mathrm{Cl}^{-}$concentrations and other major constituents and to evaluate the $\mathrm{Cl}^{-}$loads at downstream sites. Water samples were collected approximately monthly throughout the year and during winter storms as discrete grab samples collected manually or with automated samplers (appendix 1). Temperature and specific conductance were monitored at upstream and downstream sites with continuous water-quality monitors. Piezometers were installed downstream from I-95 at two of the watersheds - Four Mile River and Jordan Brook (fig. 1) - to determine $\mathrm{Cl}^{-}$concentrations in shallow groundwater samples and the extent of interaction between groundwater and surface water on the basis of specific conductance. Piezometers consisted of 1-in. inside-diameter galvanized steel drive points with holes drilled in the bottom $0.2 \mathrm{ft}$. A threaded pound cap was placed at the top, and the piezometer was driven and pounded into the streambed near the river bank to a depth of about $3 \mathrm{ft}$.

\section{Continuous Monitoring}

Continuous monitoring of water quality at each sampling site was accomplished by using a water-quality monitoring instrument for measurement of temperature and specific conductance at 10 -minute intervals. All procedures relating to water-quality monitors (calibration, maintenance, record computation, storage, and archiving) are described by Wagner and others (2006). The data record for continuous temperature and specific conductance had some gaps caused by equipment malfunction at some sites (figs. 4-7; appendixes 2-5). At Oil Mill Brook, the specific conductance probe lost calibration on a few occasions, so data were removed; also, the waterquality monitor at the Oil Mill Brook downstream site was 
moved upstream about $40 \mathrm{ft}$ on April 5, 2010. At the Stony Brook upstream site, specific conductance data are missing for May 20-29, 2009, September 17-28, 2009, June 21August 16, 2010, and September 3-15, 2010; the water-quality monitor was moved upstream $100 \mathrm{ft}$ on September 15, 2010, to avoid inflows from a parking lot and other road drainage. At the Stony Brook downstream site, specific conductance data are missing for December 9-16, 2010, and for June 21August 11, 2010, and estimated $\mathrm{Cl}^{-}$concentration data (and streamflow data) are missing for June 21, 2010-August 11, 2010. At the Jordan Brook upstream site, specific conductance data are missing for April 21-May 5, 2009.

\section{Water-Quality Sampling and Laboratory Analysis}

Water-quality grab samples were collected (1) approximately monthly during routine conditions, (2) during baseflow conditions, and (3) during winter storm or runoff events, including warm periods during which snow or ice melted. Field characteristics, which include water temperature, $\mathrm{pH}$, and specific conductance, were measured during sample collection in accordance with USGS procedures described by Wilde (2004, 2005). Grab samples were analyzed for specific conductance and $\mathrm{Cl}^{-}$concentrations, and samples collected at other times, including during base-flow conditions and during some winter storms, were analyzed for major ions (appendix 1). Samples were collected at stream sites during base-flow conditions on August 19, 2009, and again on September 15, 2010, to determine the background major-ion chemistry of groundwater (appendix 1). During base-flow (low-flow) conditions, most streamflow is derived from groundwater discharge along the stream course. Stiff diagrams were used to depict concentrations of major ions in samples collected at all eight stream sites during base flow on August 19, 2009, and at the Oil Mill Brook and Stony Brook upstream sites during higher flows in February and March 2009 (fig. 8). Automated samplers were only used at the downstream sites to collect several sets of samples during winter storms. During periods in which air temperatures were below about $-5^{\circ} \mathrm{C}$, the automated sampler intake lines were prone to problems with freezing before water could be pumped into the sample bottles. Trace elements and nutrients were analyzed in samples from Four Mile River and Jordan Brook for comparison with stream piezometer samples. All water samples collected were analyzed by the USGS National Water Quality Laboratory in Denver, Colorado, using the methodology described in Fishman and Friedman (1989).

\section{Quality Assurance}

Field sensors were regularly cleaned and calibrated with standard solutions and checked periodically with independent field and laboratory sensors. Continuous stage data and water-quality data were checked and corrected or censored for interruptions or shifts caused by debris, ice, or low-flow condi- tions. During conditions of high flow, several measurements typically were made to verify the consistency of temperature and specific conductance. Quality-control procedures for the collection of continuous specific-conductance data followed procedures described in Wagner and others (2006).

Field quality-control procedures included the collection and analysis of replicate and blank samples. Field-blank samples provided information on bias or possible contamination during sample collection, processing, or analysis. Analytical results from the field-blank samples showed that concentrations of constituents were less than the reporting level. Analysis of replicate samples provided information on the variability of analytical results caused by sample collection, processing, and analysis. Analytical methods used in the laboratory for analysis of constituent concentrations were reported to be accurate within 3 to 12 percent for major ions, depending on the ionic concentration and the analytical method used (Fishman and Friedman, 1989).

\section{Data Analysis}

Data analysis included estimating $\mathrm{Cl}^{-}$yield and load from atmospheric deposition, graphical plotting of concentrations of water-quality constituents, statistical tests to compare results among the sites, and statistical analyses of the relations between ancillary variables and $\mathrm{Cl}^{-}$concentrations and loads in surface water. Stiff diagrams, which are graphical representations of chemical analyses (Stiff, 1951), were used to display the major ion composition of water samples.

\section{Estimation of Chloride Loads in Atmospheric Deposition}

The $\mathrm{Cl}^{-}$yield and load from atmospheric deposition was estimated by using the monthly median concentrations at the three NADP stations (fig. 1; table 3) and the amount of rainfall at the National Weather Service weather station at the GrotonNew London airport (KGON; fig. 1), then calculating the $\mathrm{Cl}^{-}$mass per unit area. Constituent concentrations measured at these NADP wet deposition sites do not include dry deposition, which can be 20 to 60 percent of the total atmospheric deposition of constituents (National Atmospheric Deposition Program, 2012). The $\mathrm{Cl}^{-}$load estimated from wetfall deposition was multiplied by a factor of two (Prych, 1998) to represent the total atmospheric deposition.

\section{Estimation of Chloride Concentrations and Loads in Streams}

Continuous $\mathrm{Cl}^{-}$concentrations and daily $\mathrm{Cl}^{-}$loads were estimated by using LOADEST, a load estimator computer program (Runkel and others, 2004). Data analyzed for dissolved $\mathrm{Cl}^{-}$in this study contained no censored data. Given a set of discrete water-quality measurements at each station and 


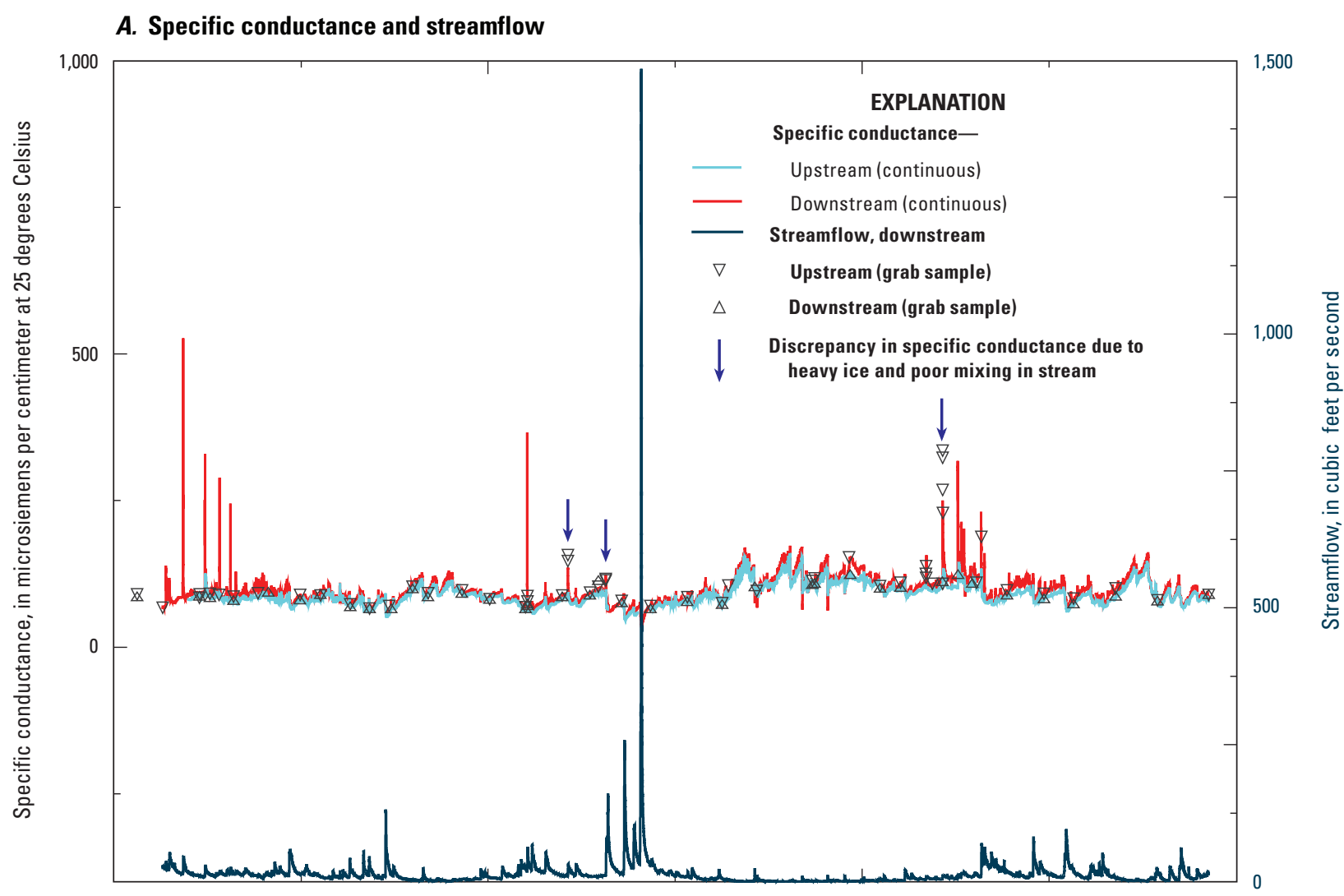

B. Chloride concentration

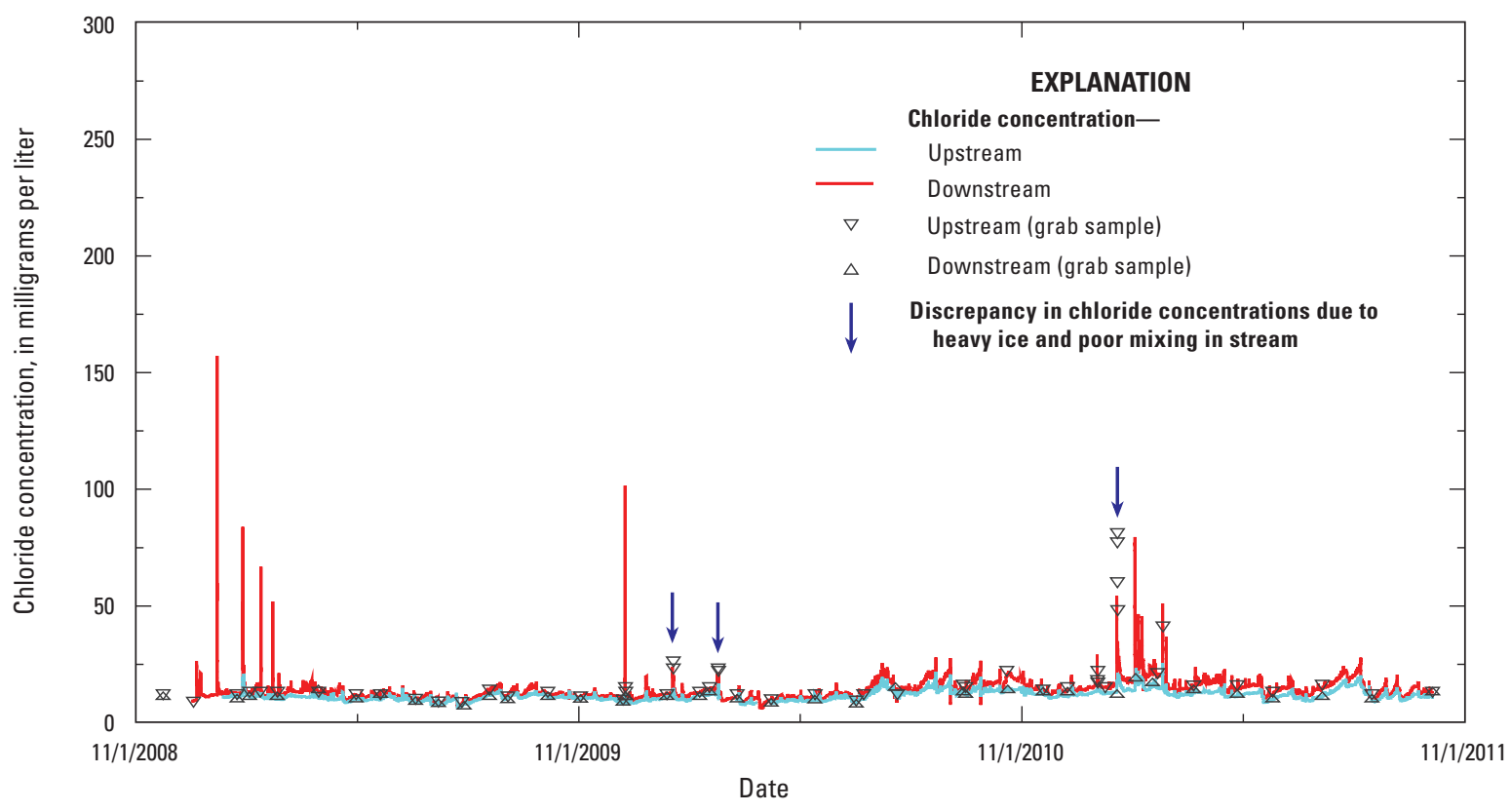

Figure 4. A, specific conductance in grab samples and continuous specific conductance at Four Mile River upstream and downstream sites, and continuous streamflow at the downstream site, and $B$, chloride concentrations measured in grab samples and estimated continuous chloride concentrations at Four Mile River upstream and downstream sites, southeastern Connecticut, from November 2008 to September 2011. 


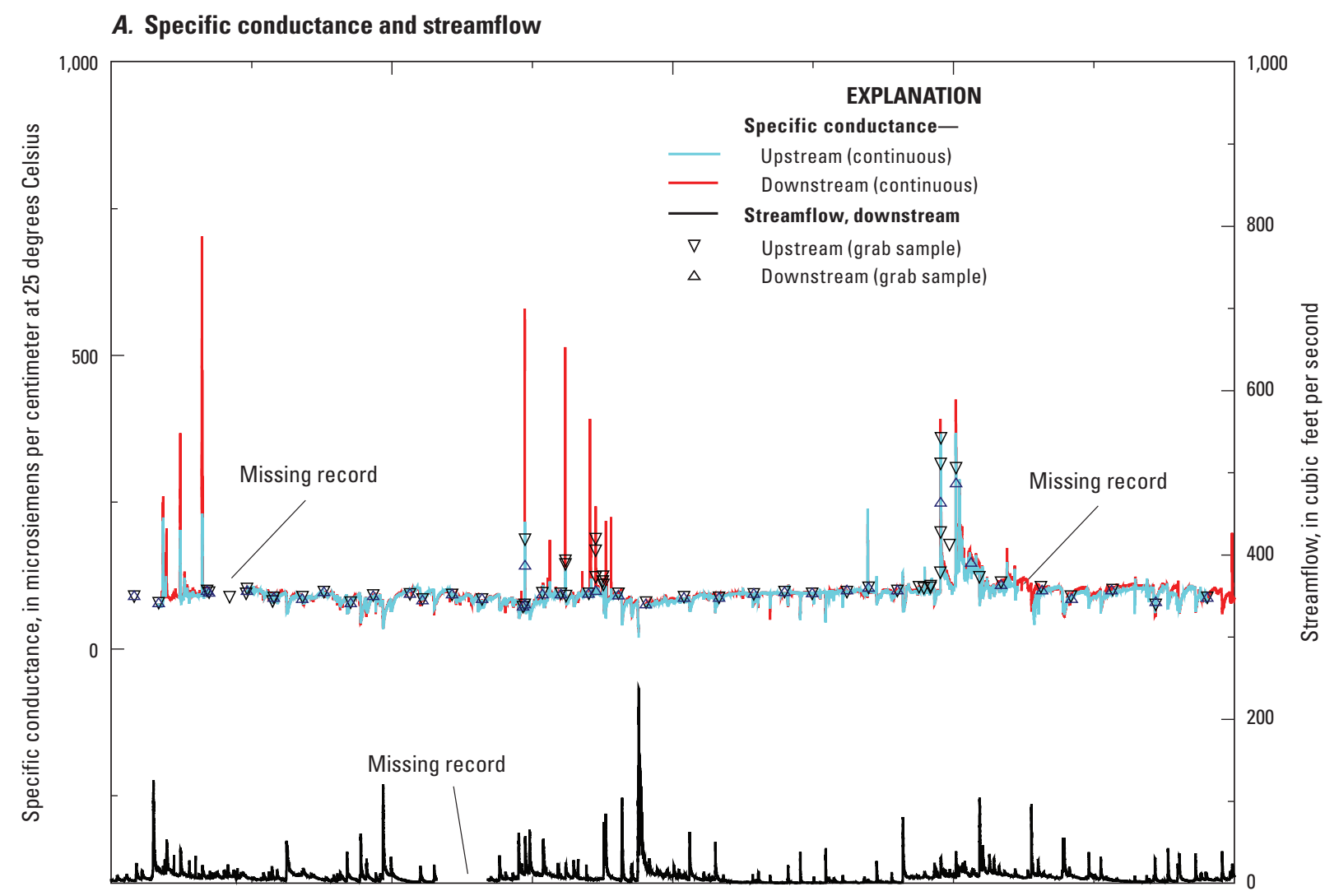

\section{B. Chloride concentration}

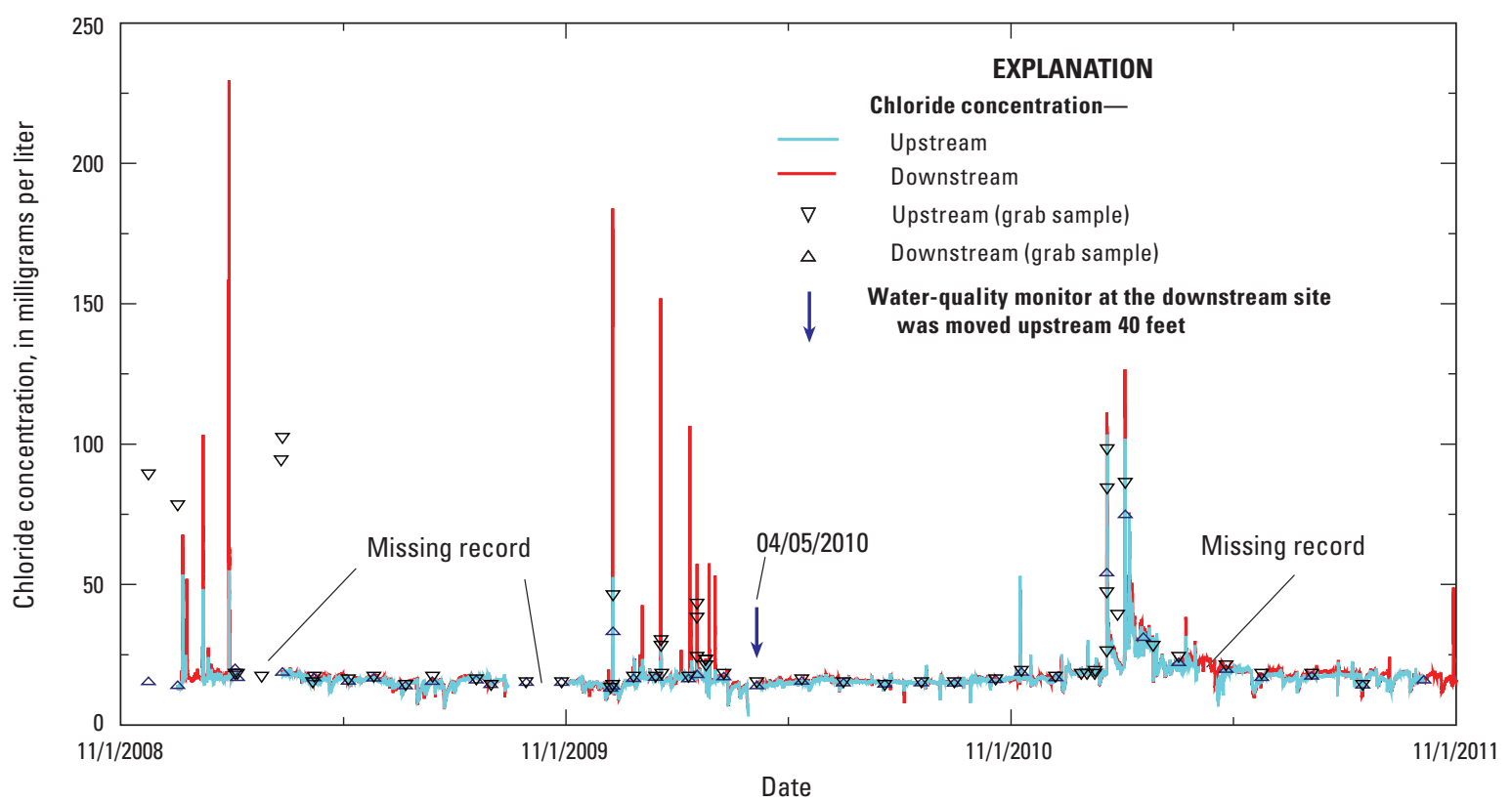

Figure 5. A, specific conductance in grab samples and continuous specific conductance at Oil Mill Brook upstream and downstream sites, and continuous streamflow at the downstream site, and $B$, chloride concentrations measured in grab samples and estimated continuous chloride concentrations at Oil Mill Brook upstream and downstream sites, southeastern Connecticut, from November 2008 to September 2011. 
A. Specific conductance and streamflow

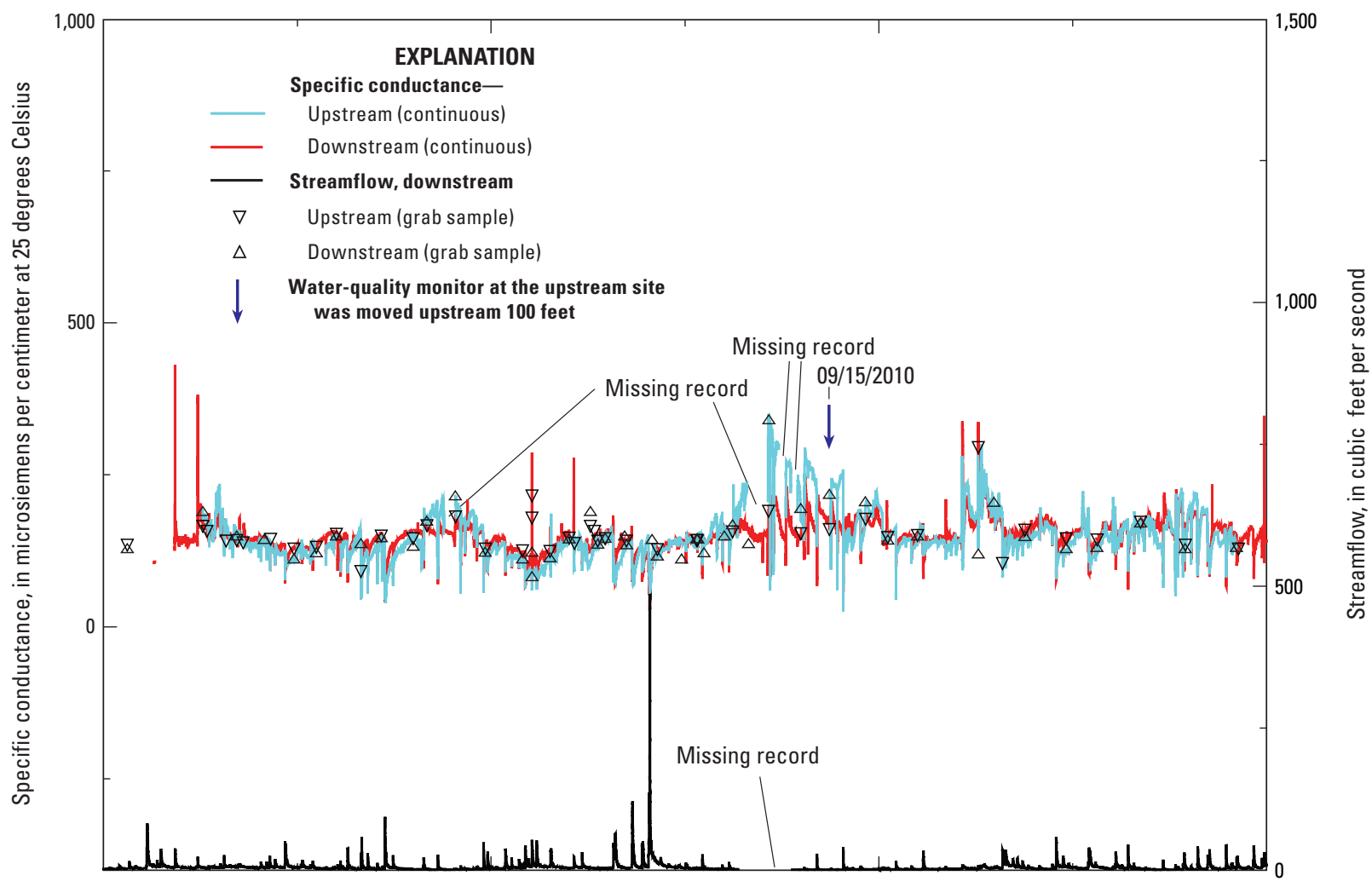

\section{B. Chloride concentration}

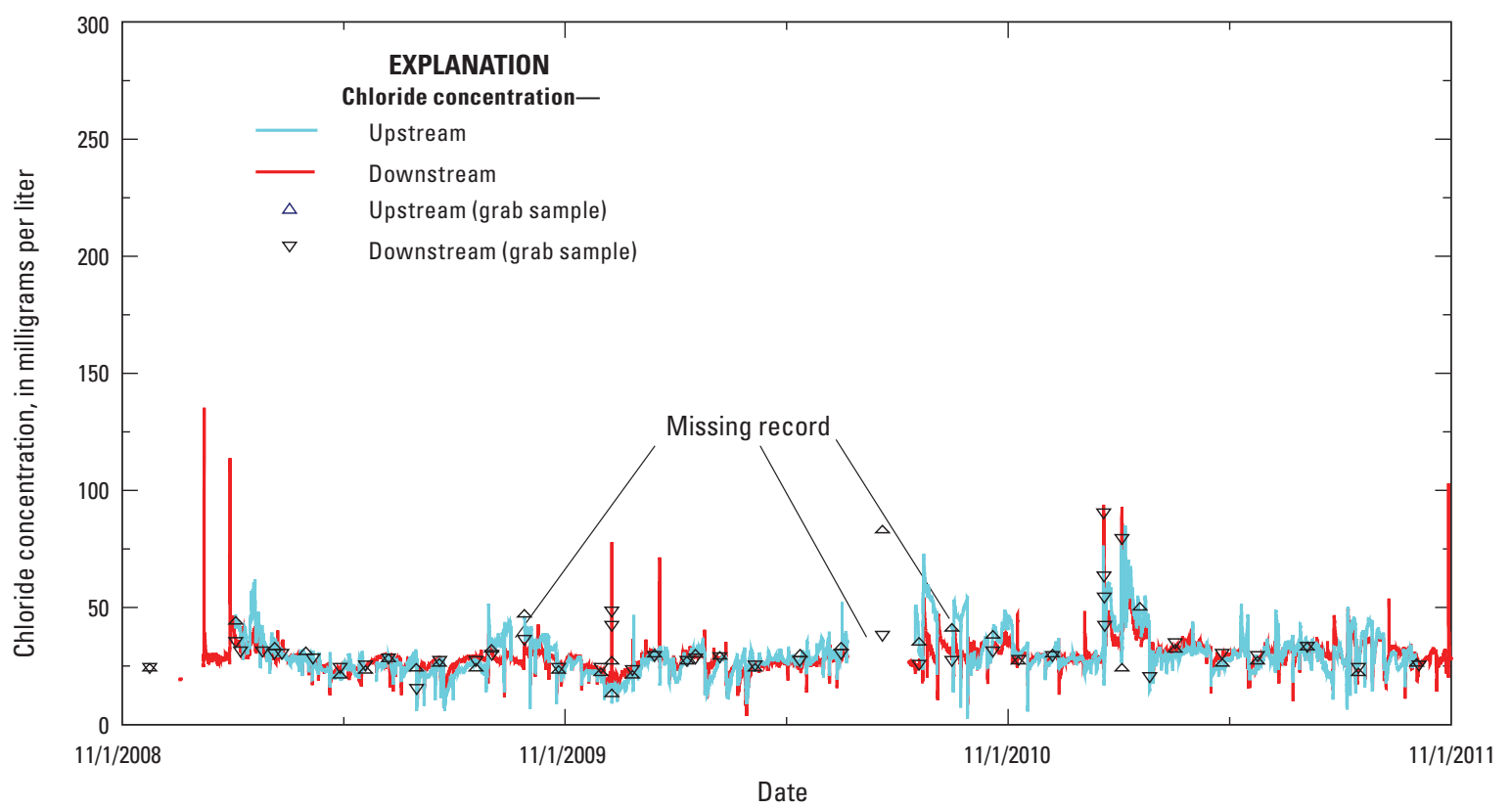

Figure 6. A, specific conductance in grab samples and continuous specific conductance at Stony Brook upstream and downstream sites, and continuous streamflow at the downstream site, and $B$, chloride concentrations measured in grab samples and estimated continuous chloride concentrations at Stony Brook upstream and downstream sites, southeastern Connecticut, from November 2008 to September 2011. 


\section{A. Specific conductance and streamflow}

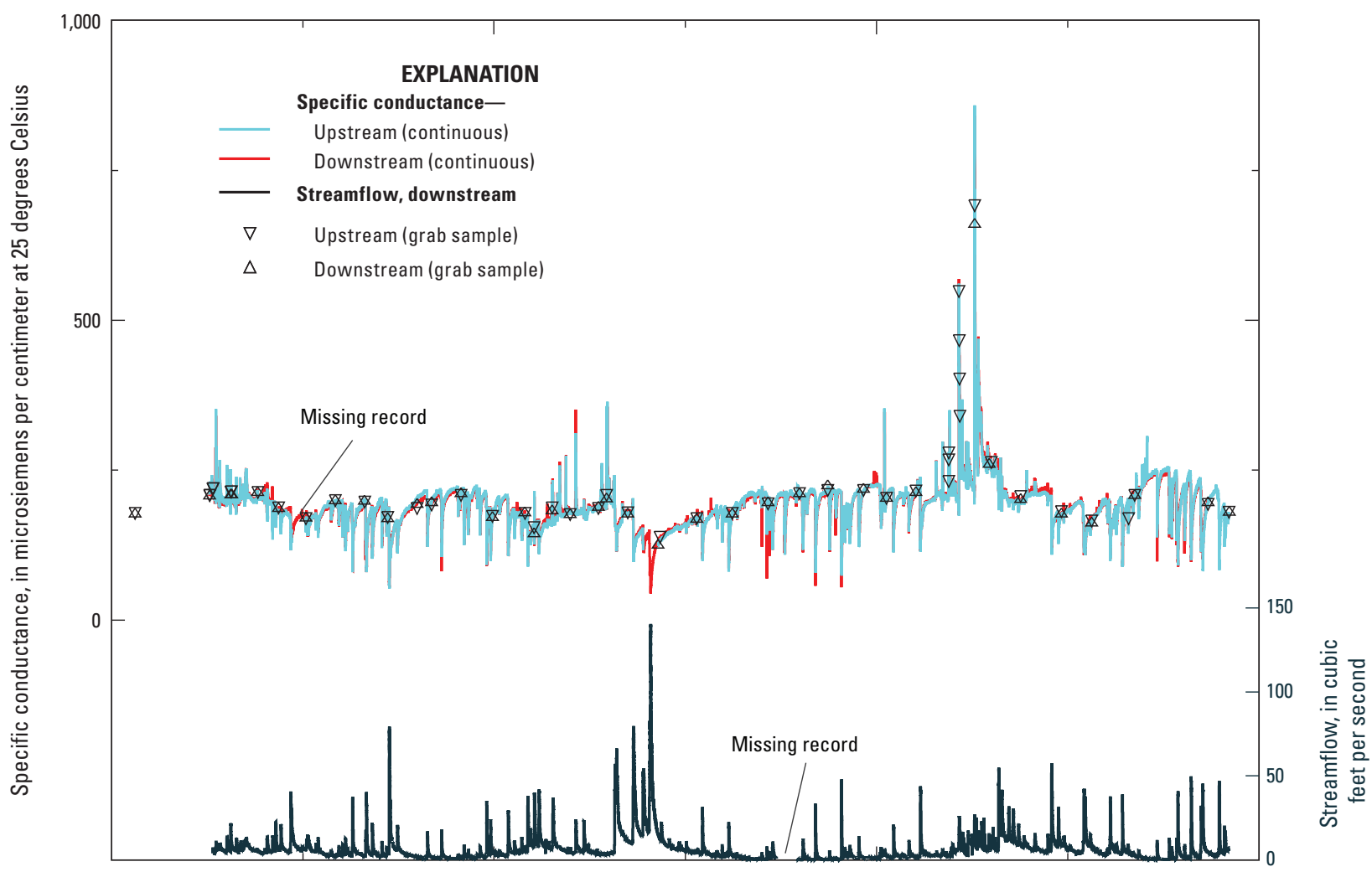

\section{B. Chloride concentration}

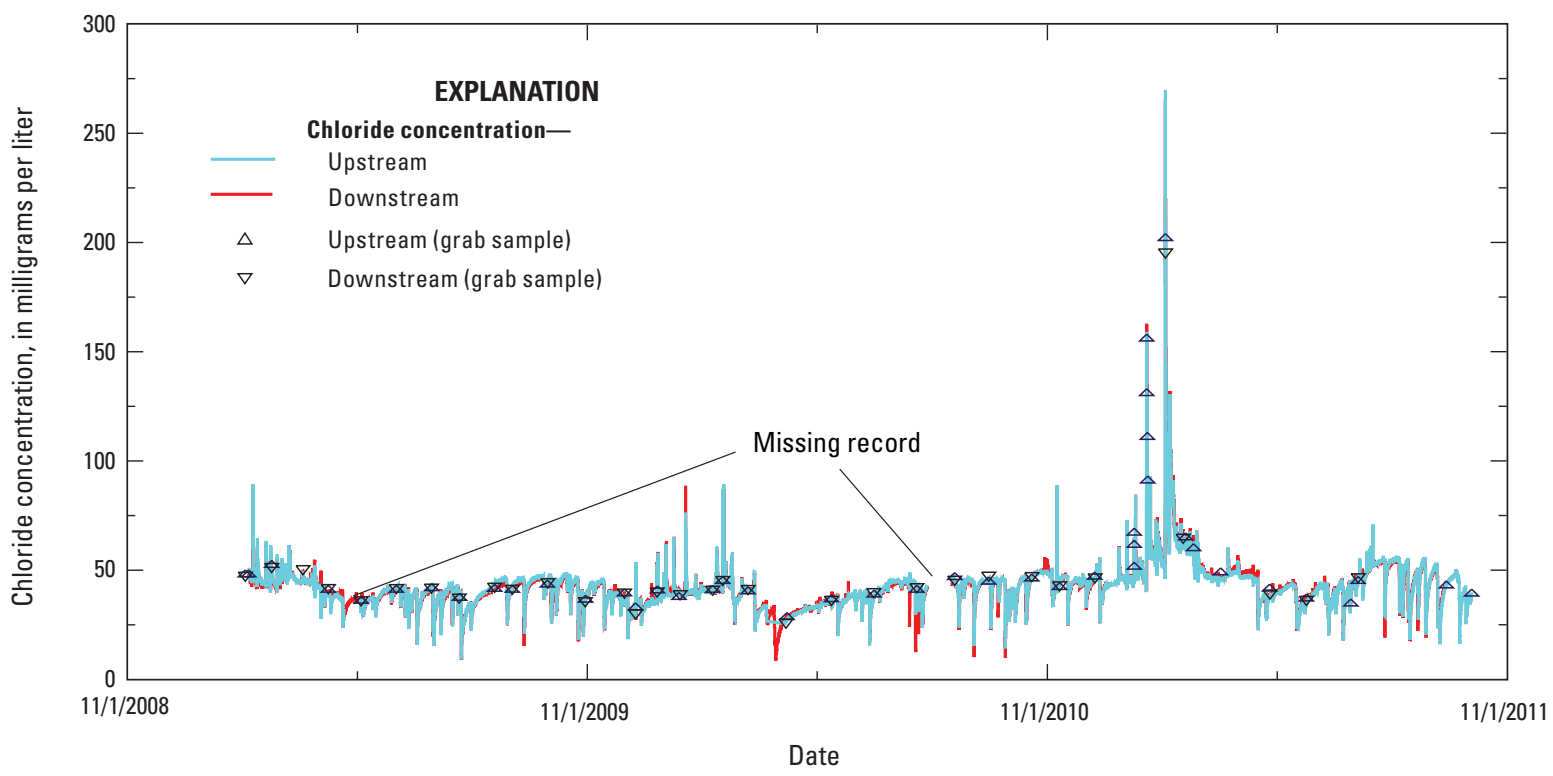

Figure 7. $A$, specific conductance in grab samples and continuous specific conductance at Jordan Brook upstream and downstream sites, and continuous streamflow at the downstream site, and $B$, chloride concentrations measured in grab samples and estimated continuous chloride concentrations at Jordan Brook upstream and downstream sites, southeastern Connecticut, from November 2008 to September 2011. 

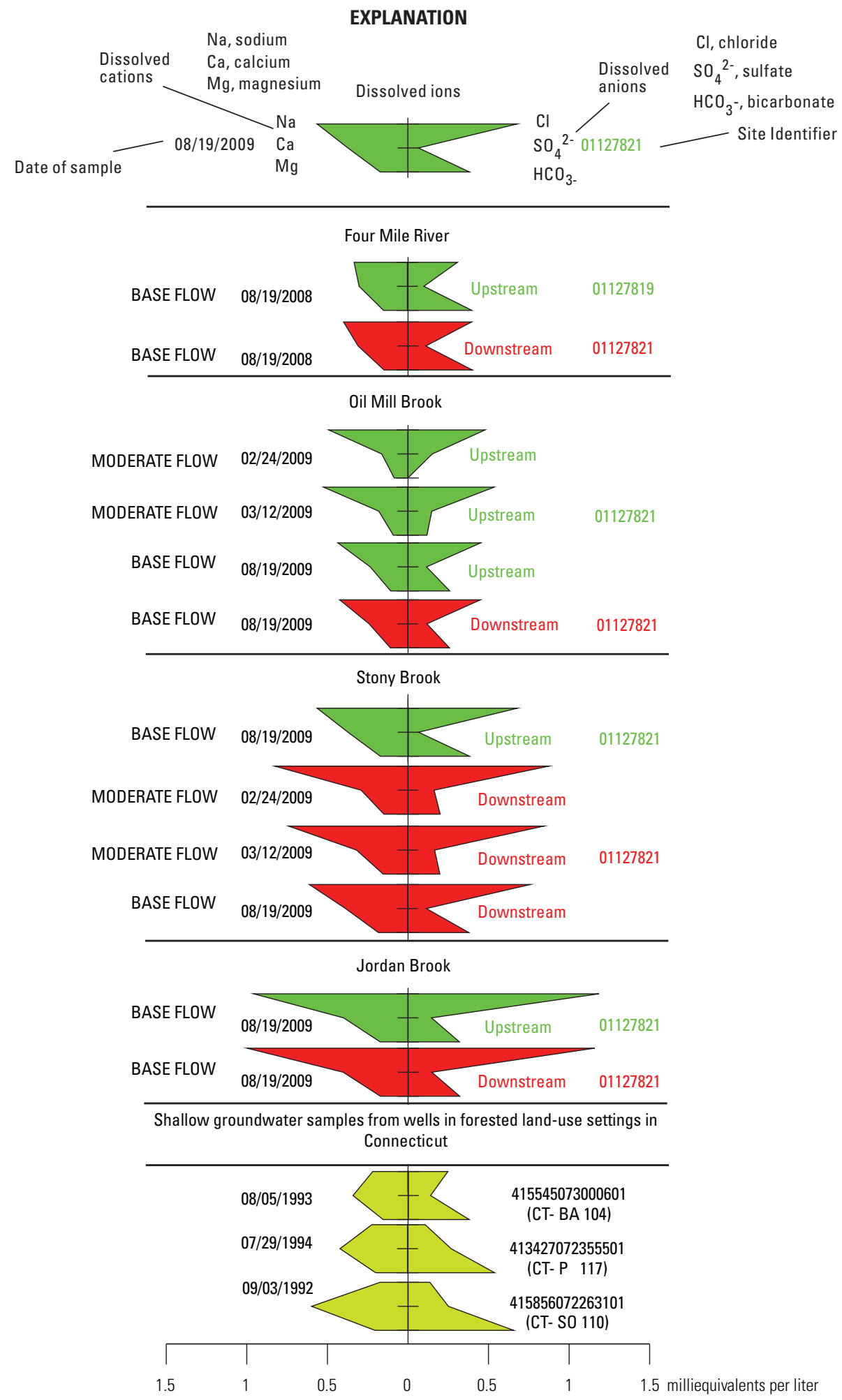

Figure 8. Concentrations of major ions in water at upstream and downstream monitoring sites at Four Mile River, Oil Mill Brook, Stony Brook, and Jordan Brook, southeastern Connecticut, and shallow groundwater samples from wells in forested land-use settings in Connecticut. 
corresponding streamflow data, LOADEST assists the user in developing regression models for the estimation of constituent concentration and load at each site. Explanatory variables in the regression model may include various functions of streamflow, time, seasonal terms, and additional user-specified data. The formulated regression models then are used to estimate constituent concentrations and loads over a user-specified time interval. Throughout this report, these estimated $\mathrm{Cl}^{-}$concentrations are referred to as "estimated" continuous $\mathrm{Cl}^{-}$concentrations, whereas "observed" refers to $\mathrm{Cl}^{-}$concentrations measured in grab samples.

The variables selected in the final LOADEST regressions include standard LOADEST regression variables including the natural $\log$ of streamflow $(\ln (\mathrm{Q}))$ and decimal $\mathrm{T}$ (sample date and time in decimal format). In addition, the following variables were added: a winter season indicator variable (for samples collected October-March) and the natural log of the specific conductance measurements $(\ln (\mathrm{SC}))$. Data on the LOADEST regression variables and coefficients are given in table 7 .

Chloride load and concentration prediction estimates with time during the study were made in two ways using LOADEST. A calibration dataset was compiled for each site, including the laboratory concentrations for chloride from manual and automatic sample collection and other explanatory variables, including the sample date and time, specific conductance, and the streamflow associated with the sample. For sites upstream from I-95, streamflow at the downstream site was used in the LOADEST calibration data file. Load predictions were made only for the downstream site in each of the four watersheds, and estimates of concentrations were made for both upstream and downstream sites.

Two types of predictions or estimations were made by using LOADEST, including (1) estimates of daily chloride load and (2) instantaneous estimates of chloride concentrations. The prediction file that was assembled for the daily mean load included the following variables: date, daily mean flow, and daily mean specific conductance for the downstream sites. Loads were not estimated for the upstream sites because the sites did not have streamgages. For estimates of instantaneous chloride concentrations for each site, a prediction file was assembled that contained data on date and time, instantaneous streamflow, and instantaneous specific conductance. This file was used with the LOADEST regression model to compute instantaneous chloride.

Table 7. Parameter estimates and coefficients of determination for explanatory variables determined for chloride concentrations and loads, at monitoring sites upstream and downstream from Interstate 95, southeastern Connecticut.

[Shaded areas indicate variables not significant at less than or equal to 0.05 . ID, identification number; $\ln$, natural log; Q, streamflow (cubic feet per second); Decimal T, time in decimal format; Period.Q, streamflow during winter period; SC, specific conductance; $\mathrm{R}^{2}$, coefficient of determination]

\begin{tabular}{lcccccccc}
\hline \multicolumn{1}{c}{ Station name } & $\begin{array}{c}\text { Station } \\
\text { ID }\end{array}$ & $\begin{array}{c}\text { Regression } \\
\text { intercept }\end{array}$ & $\begin{array}{l}\text { In } \\
\text { (0) }\end{array}$ & $\begin{array}{c}\text { Decimal } \\
\text { T }\end{array}$ & $\begin{array}{c}\text { Winter } \\
\text { period } \\
\text { indicator }\end{array}$ & 2Period.0 & $\begin{array}{c}\text { In } \\
\text { (SC) }\end{array}$ & R $^{2}$ \\
\hline Four Mile River upstream of I-95 & 01127819 & -7.40097 & 1.07968 & 0.03132 & -0.00376 & 0.05963 & 1.28928 & 99.37 \\
Four Mile River downstream of I-95 & 01127821 & -7.82024 & 1.08327 & 0.05589 & -0.00833 & 0.07098 & 1.39698 & 99.51 \\
Oil Mill Brook, upstream & 0112779135 & -6.94921 & 1.08785 & 0.01249 & 0.01522 & -0.01703 & 1.23141 & 99.89 \\
Oil Mill Brook, downstream & 011277914 & -7.01412 & 1.08983 & -0.00297 & -0.00247 & -0.03065 & 1.28209 & 99.78 \\
Stony Brook, upstream & 0112779155 & -8.37784 & 1.10608 & -0.01307 & 0.05200 & -0.07741 & 1.41911 & 99.52 \\
Stony Brook, downstream & 011277916 & -8.04048 & 1.06418 & -0.00240 & 0.04524 & -0.03821 & 1.36749 & 99.84 \\
Jordan Brook, upstream & 011277695 & -7.96556 & 1.01655 & 0.00658 & -0.01324 & 0.03226 & 1.17312 & 99.95 \\
Jordan Brook, downstream & 011277696 & -7.89011 & 1.10157 & 0.01069 & -0.01325 & 0.02903 & 1.18044 & 99.96 \\
\hline
\end{tabular}

${ }^{1}$ The winter season indicator is a binary variable identifying samples or predictions for November to March.

${ }^{2}$ The flow during the winter period is used because of the potential that winter sample concentrations have a different relation with flow. For example, at site 011277916 , the regression equation used outside the winter period is $\ln (\mathrm{L})=-8.04048+1.06418 \times \ln (\mathrm{Q})-0.00240+1.36749 \times \ln (\mathrm{SC})$, where $\mathrm{L}=\operatorname{load}$. During the winter period, the equation is $\ln (\mathrm{L})=(-8.04048+0.04524)+(1.06418-0.03821) \times \ln (\mathrm{Q})-0.00240(\mathrm{~T})+1.36749 \times \ln (\mathrm{SC})$. Explanation of the seasonal variables is given in Runkel and others (2004, “4.2 Application 2: Analysis of an Uncensored Constituent using a Seasonal Model”). 
Table 8. Results of the $A$, Kruskal-Wallis rank sum test, and $B$, Tukey's honest significance difference test for peak specific conductance, Brook watersheds in Connecticut.

[Shaded areas indicate the probability that the null hypothesis will be rejected at a level of significance of less than 0.05. R, river; Br, brook; SC, specific conductance;

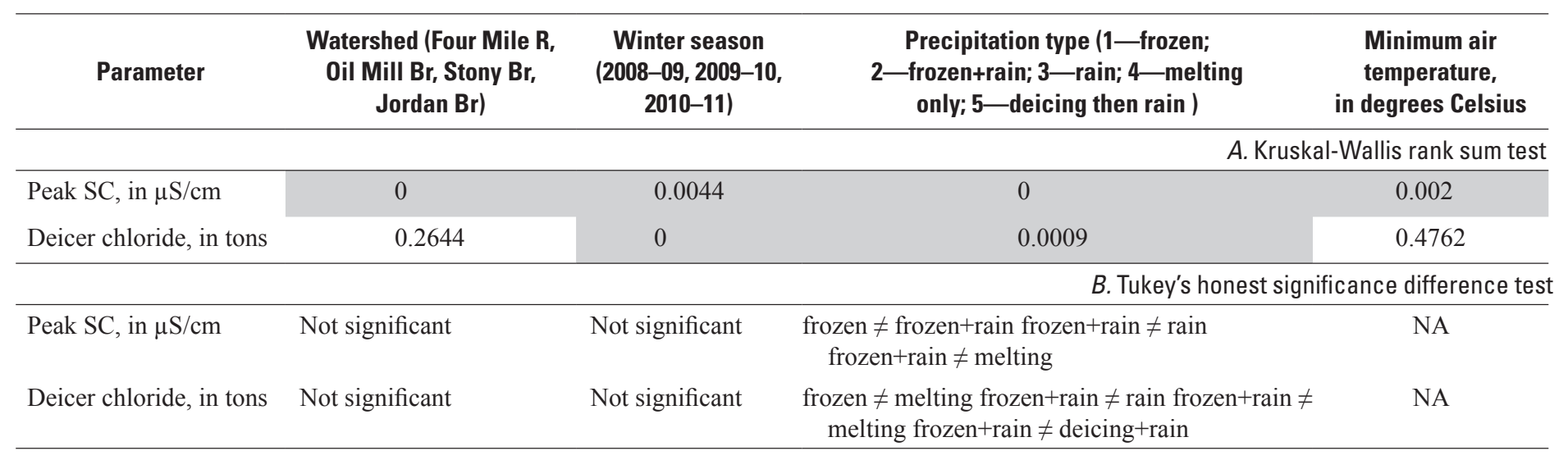

\section{Statistical Tests}

Because of the non-normal distribution of data, nonparametric statistical procedures (Conover and Iman, 1981; Iman and Conover, 1983; Helsel and Hirsch, 1995) were used for analysis. These procedures measure the degree of association between the distributions of element data when grouped by watershed and deicing event characteristics.

The Kruskal-Wallis rank sum test was used to determine significant differences in mean peak specific conductance among the winter storm and watershed characteristics factors (table 8A). The one-way Kruskal-Wallis rank sum test is a nonparametric equivalent to the ANOVA and was used to test which factors differed from others; in other words, it tested whether or not the mean peak specific conductance of streams varied significantly among the storm and watershed characteristics (explanatory variable or factor).

Tukey's honest significance difference (HSD) test (Sokal and Rohlf, 1969; Stoline, 1981; Helsel and Hirsch,1995), a multiple-comparison procedure, was used to discriminate which group or groups of data, based on watershed or winter season, differed in peak specific conductance or deicing $\mathrm{Cl}^{-}$when the Kruskal-Wallis rank sum test rejected the null hypothesis at $\mathrm{p}$-value $<0.05$ (table $8 B$ ). For all possible pairwise comparisons, the Tukey's HSD test uses the within-group variance to calculate the minimum difference in mean rank that is necessary to consider groups significantly different. The factors with significant differences are indicated by the " $\neq$ " symbol (for example, frozen precipitation $\neq$ frozen precipitation + rain) at $\mathrm{p}$-value $<0.05$ (table $8 B)$.

\section{Multiple Linear Regression Modeling}

Multiple linear regression models were developed to describe peak chloride concentrations for samples collected from stream sites and factors related to road deicing that could be used to estimate peak $\mathrm{Cl}^{-}$concentrations during winter storms. Explanatory variables that were evaluated for use in the models include land-use/land-cover characteristics (percentage of developed land); length of highway lanes; watershed area; the types, amounts, and rates for deicers; storm characteristics; streamflow; and percentage of coarse stratified drift deposits. Values were selected on the basis of plausibility, statistical significance, and the distribution of residuals.

\section{Factors That Affect Chloride Concentrations, Loads, and Yields}

Factors that affect $\mathrm{Cl}^{-}$concentrations, loads, and yields in the watersheds are discussed here, including the estimated $\mathrm{Cl}^{-}$ load in atmospheric deposition. Specific conductance and estimated $\mathrm{Cl}^{-}$concentrations varied temporally with streamflow and season, and spatially between upstream and downstream sites on each of the four streams. These specific conductance and estimated $\mathrm{Cl}^{-}$concentration responses also can be related to the type and amount of road deicers applied by ConnDOT to I-95 and associated roads across the four watersheds in response to (or preceding) ice or snow events (table 5). Precipitation and (or) stormwater-runoff events generally coincided with an increased response of stream stage and streamflow. Streamflow data were compared to precipitation events and streamwater chemistry to determine sources and timing of $\mathrm{Cl}^{-}$ concentrations and loads.

\section{Streamflow and Watershed Yield}

Streamflow varied among sites from a mean of 4.8 cubic feet per second $\left(\mathrm{ft}^{3} / \mathrm{s}\right)$ at Stony Brook to a mean of $14 \mathrm{ft}^{3} / \mathrm{s}$ at 
chloride from road deicers, and winter storm and watershed characteristics in the Four Mile River, Oil Mill Brook, Stony Brook, and Jordan

$\mu \mathrm{S} / \mathrm{cm}$; microsiemens per centimeter at 25 degrees Celsius; $\mathrm{ft}^{3} / \mathrm{s}$, cubic foot per second; $\neq$, significantly different; NA, not analyzed]

\begin{tabular}{|c|c|c|c|c|c|c|c|c|}
\hline $\begin{array}{c}\text { Baseflow SC, } \\
\text { in } \mu \mathrm{S} / \mathrm{cm}\end{array}$ & $\begin{array}{c}\text { Daily } \\
\text { mean SC, } \\
\text { in } \mu \mathrm{S} / \mathrm{cm}\end{array}$ & $\begin{array}{l}\text { Streaflow, } \\
\text { in } \mathrm{ft}^{3} / \mathrm{s}\end{array}$ & $\begin{array}{l}\text { Impervious } \\
\text { cover, } \\
\text { in percent }\end{array}$ & $\begin{array}{l}\text { Pre-existing } \\
\text { snow pack }\end{array}$ & $\begin{array}{l}\text { Deicer chloride, } \\
\text { in tons }\end{array}$ & $\begin{array}{l}\text { Subfreezing } \\
\text { time before } \\
\text { storm, in hours }\end{array}$ & $\begin{array}{l}\text { Precipitation } \\
\text { duration, } \\
\text { in hours }\end{array}$ & $\begin{array}{c}\text { Precipitation } \\
\text { amount, } \\
\text { in inches }\end{array}$ \\
\hline 0 & 0.0364 & 0.2822 & 0 & 0.0011 & 0.2818 & 0.0017 & 0.002 & 0 \\
\hline 0.2644 & 0.4563 & 0.7838 & 0.2644 & 0.0007 & NA & 0 & 0 & 0 \\
\hline NA & NA & NA & NA & NA & NA & NA & NA & NA \\
\hline NA & NA & NA & NA & NA & NA & NA & NA & NA \\
\hline
\end{tabular}

Four Mile River. Streamflow at Four Mile River was as great as $1,500 \mathrm{ft}^{3} / \mathrm{s}$ during a spring rain event in March 2010 and reflects the larger drainage basin area. The watershed yield (streamflow per unit of watershed area, expressed in cubic feet per second per square mile) is a measure of drainage intensity. The annual mean watershed yield was only 1.5 cubic feet per second per square mile $\left(\left[\mathrm{ft}^{3} / \mathrm{s}\right] / \mathrm{mi}^{2}\right)$ at the Oil Mill Brook downstream site but 2.3 to $2.6\left(\mathrm{ft}^{3} / \mathrm{s}\right) / \mathrm{mi}^{2}$ at the three other downstream sites (fig. 9); the lower value of annual mean watershed yield at the Oil Mill Brook downstream site could result from less runoff and more groundwater recharge compared to the other watersheds.

\section{Conductance and Chloride in Four Streams Along Interstate 95}

Median continuous specific conductance and estimated $\mathrm{Cl}^{-}$ concentrations were lowest at the Four Mile River upstream site (87 microsiemens per centimeter at $25^{\circ} \mathrm{C}[\mu \mathrm{S} / \mathrm{cm}]$ and $11 \mathrm{mg} / \mathrm{L}$, respectively) and highest at the Jordan Brook upstream site $(195 \mu \mathrm{S} / \mathrm{cm}$ and $42 \mathrm{mg} / \mathrm{L}$, respectively) from November 1, 2008, through September 30, 2011 (table 9). The primary natural source of $\mathrm{Cl}^{-}$in the watersheds is atmospheric precipitation, so $\mathrm{Cl}^{-}$concentrations in wetfall precipitation at NADP sites were used to estimate $\mathrm{Cl}^{-}$loads in atmospheric deposition (fig. 1). Median $\mathrm{Cl}^{-}$concentrations ranged from $0.19 \mathrm{mg} / \mathrm{L}$ in wetfall precipitation at an inland site in Abington, Conn. (CT15), to $0.45 \mathrm{mg} / \mathrm{L}$ at a site in Lexington, Massachusetts (MA13), and represent a relatively small contribution of $\mathrm{Cl}^{-}$in the watersheds compared to that from road deicers. Estimated $\mathrm{Cl}^{-}$loads in atmospheric deposition ranged from 0.0004 ton per day per square mile (ton/d) $/ \mathrm{mi}^{2}$ at inland site CT15 during October 2008-September 2011, to 0.052 (ton/d)/ $/ \mathrm{mi}^{2}$ at MA13, during October 2008-September 2010 (fig. 10; table 3). The estimates of median $\mathrm{Cl}^{-}$load from atmospheric deposition vary from 0.0048 ton per day (ton/d) for the Stony Brook watershed to 0.028 ton/d for the Four Mile River watershed (table 3).

Estimated $\mathrm{Cl}^{-}$concentrations at the four stream sites were well below the acute aquatic habitat criteria for $\mathrm{Cl}^{-}$of $860 \mathrm{mg} / \mathrm{L}$ over a 1-hour period, as well as the chronic aquatic habitat criteria of $230 \mathrm{mg} / \mathrm{L}$ averaged over 4 days (figs. 4-7). Estimated $\mathrm{Cl}^{-}$concentrations at the Jordan Brook downstream site peaked at 270 $\mathrm{mg} / \mathrm{L}$ on February 2, 2011, but only exceeded the chronic aquatic criterion of $230 \mathrm{mg} / \mathrm{L}$ for less than 2 hours. Generally, the specific conductance and $\mathrm{Cl}^{-}$concentrations in grab samples and continuous specific conductance and estimated $\mathrm{Cl}^{-}$concentrations at downstream monitoring sites were higher during winter months than at other times of the year; increases corresponded to precipitation or melting events and increased streamflow, as discussed in the section "Storm Conductance and Chloride Concentrations." During the spring and summer months, specific conductance and estimated $\mathrm{Cl}^{-}$concentrations generally decreased in response to precipitation events and peaks in streamflow that cause dilution.

\section{Base-Flow Chemistry Upstream and Downstream of Interstate 95}

The samples depicted in figure 8 show that $\mathrm{Cl}^{-}$and $\mathrm{Na}^{+}$ were the dominant ions in samples collected during base flow at all sites, and bicarbonate $\left(\mathrm{HCO}_{3}^{-}\right)$also was dominant at the Four Mile River site. Concentrations of $\mathrm{Cl}^{-}$and $\mathrm{Na}^{+}$in samples collected at Four Mile River and Stony Brook during base flow were higher at the downstream sites than at the upstream sites and probably reflect the greater contributions of shallow groundwater that was affected by deicing chemicals downstream from I-95. The concentrations of $\mathrm{HCO}_{3}^{-}, \mathrm{Ca}^{2+}$, and, to a lesser extent, magnesium $\left(\mathrm{Mg}^{2+}\right)$ at Four Mile River were comparable to concentrations of $\mathrm{Cl}^{-}$and $\mathrm{Na}^{+}$and may indicate a leachate source from a former landfill and associated septage 


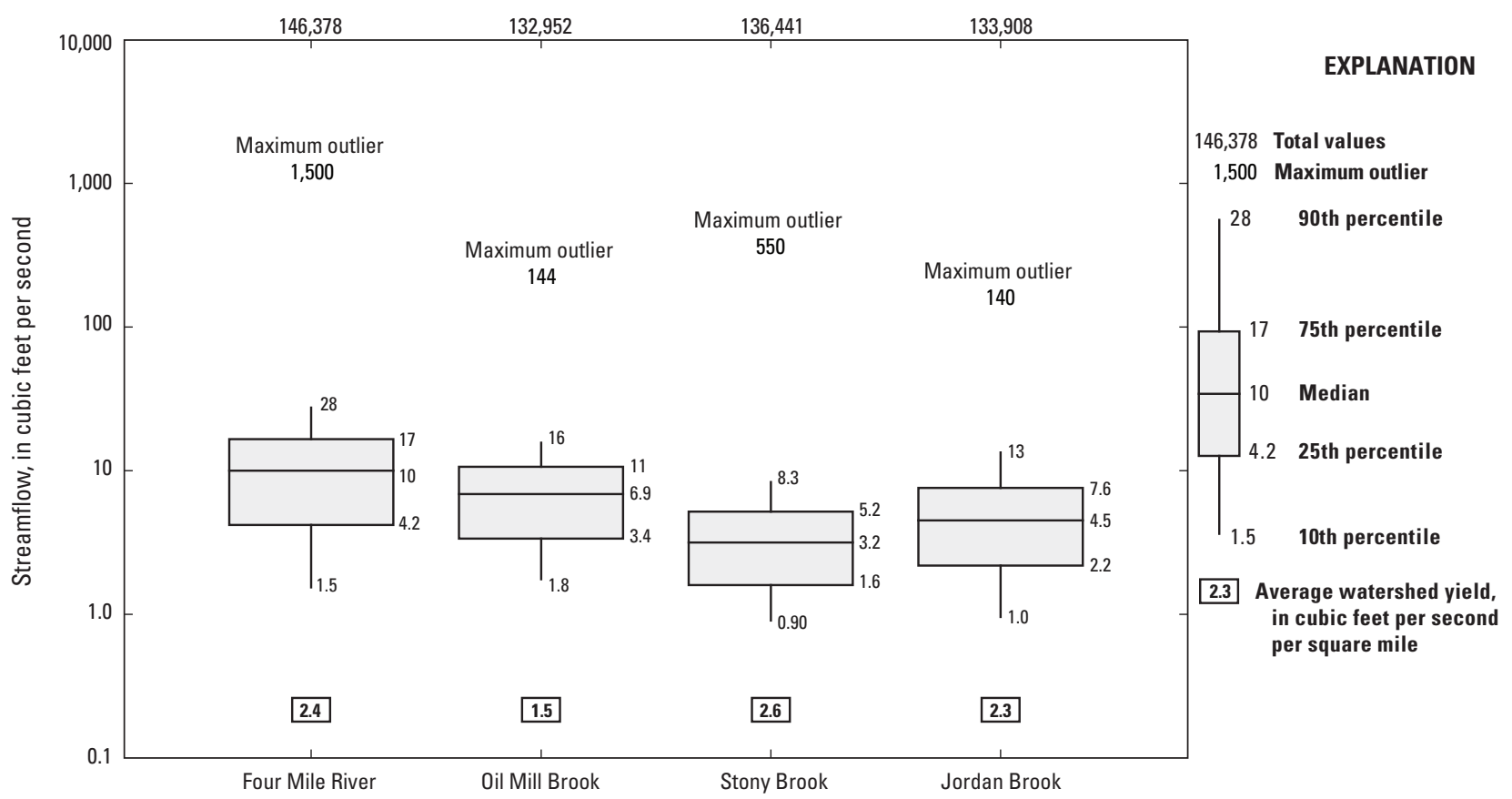

Figure 9. Distributions of continuous streamflow at the downstream monitoring sites at Four Mile River, Oil Mill Brook, Stony Brook, and Jordan Brook, southeastern Connecticut, from November 2008 to September 2011.

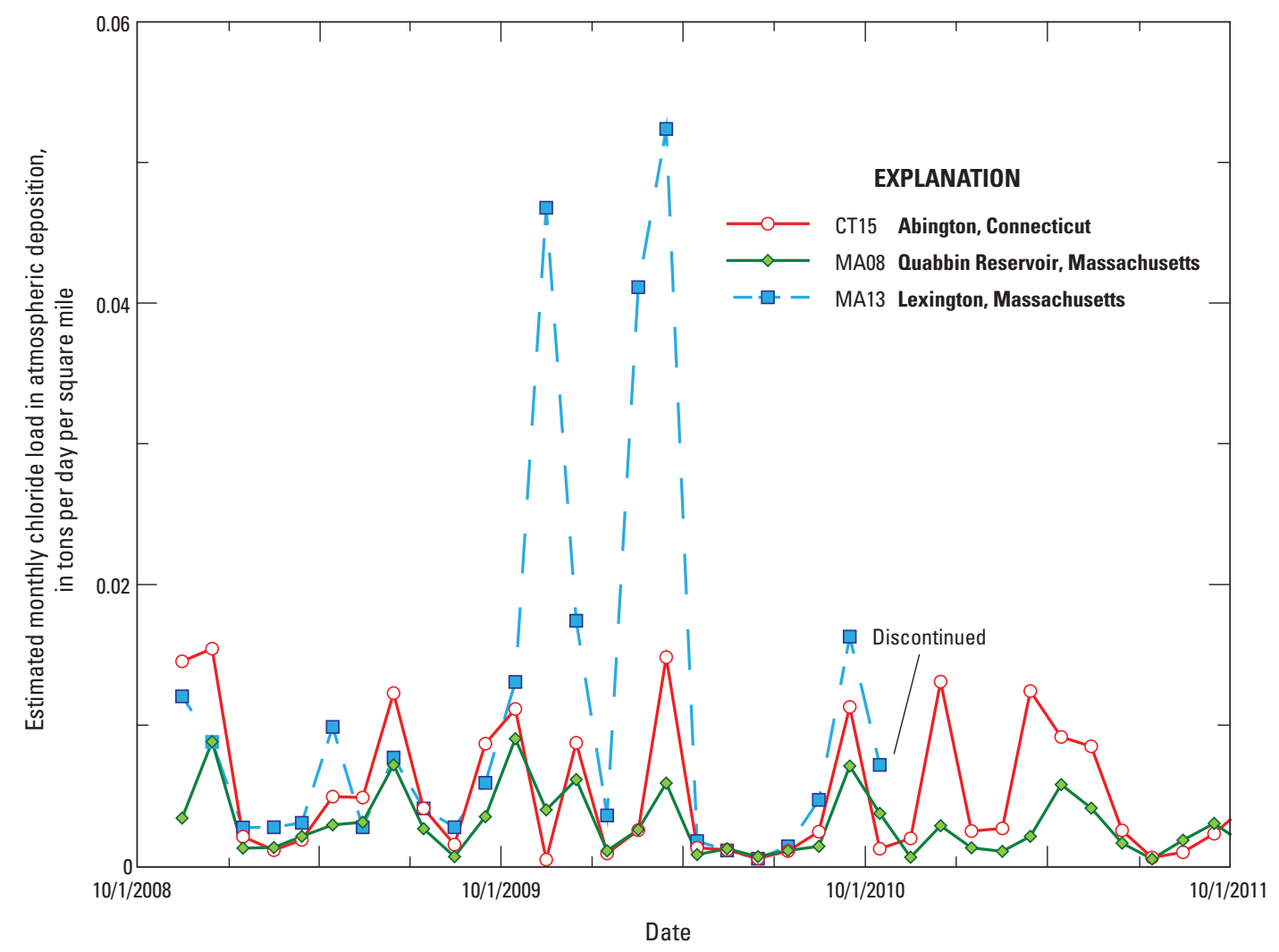

Figure 10. Estimated monthly median chloride loads in atmospheric deposition based on data from three National Atmospheric Deposition Program stations, from November 2008 to September 2011. Data are from National Atmospheric Deposition Program (2012). Estimates are based on chloride concentrations in wet deposition, but yields and loads were multiplied by a factor of two to account for dry deposition. Locations of sites are shown in figure. 1. 

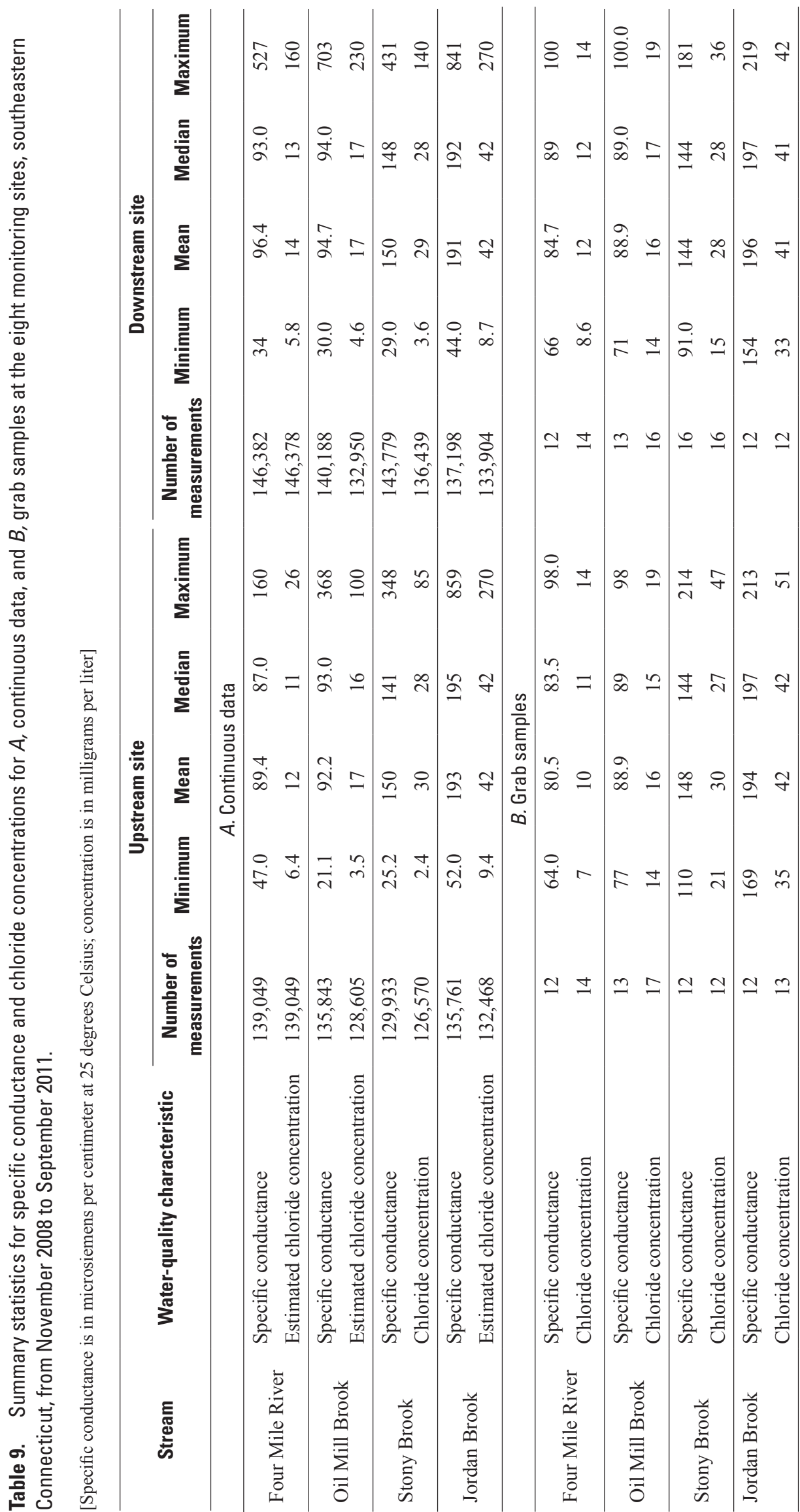
lagoon upstream from I-95 (fig. 2). The concentrations of major ions at Oil Mill Brook and Jordan Brook during base flow were similar for the upstream and downstream sites. At the Oil Mill Brook upstream site, concentrations of $\mathrm{HCO}_{3}^{-}, \mathrm{Mg}^{2+}$, and $\mathrm{Ca}^{2+}$ increased, and concentrations of $\mathrm{Na}^{+}, \mathrm{Cl}^{-}$, and sulfate $\left(\mathrm{SO}_{4}^{2-}\right)$ decreased from February to August 2009, apparently as contributions from road-deicing sources decreased and contributions from base flow increased throughout the spring and summer. Major ion concentrations in base flow at the Four Mile River sites are comparable to concentrations in shallow groundwater from undeveloped areas (Grady and Mullaney, 1998). Concentrations of major ions in groundwater samples from three shallow wells in forested areas in Connecticut (Grady and Mullaney, 1998) indicate patterns of ions that are less dominated by $\mathrm{Na}^{+}$ and $\mathrm{Cl}^{-}$and more by $\mathrm{Ca}^{2+}, \mathrm{Mg}^{2+}$, and $\mathrm{HCO}_{3}{ }^{-}$compared to patterns of ions in streamwater samples (fig. 8).

Specific conductance values and $\mathrm{Cl}^{-}$concentrations in groundwater samples from the Four Mile River piezometer were much higher than those in surface-water samples and may reflect leachate from a landfill and septage lagoon, both inactive, and from highway deicers.

\section{Stormflow Conductance and Chloride Concentrations}

During winter months, specific conductance and estimated $\mathrm{Cl}^{-}$concentrations in streams generally increased along with streamflow in response to precipitation or melting events as road deicers were washed from road surfaces by stormwater runoff. Periods of increased continuous specific conductance were observed at downstream monitoring sites, along with estimated $\mathrm{Cl}^{-}$concentrations, (1) in direct response to a storm or other deicing activity or (2) during a period of rain or melting that occurred after a storm or activity (table 10; appendixes 2-5). Specific conductance peaks also were observed in the spring after deicing practices had ended, apparently resulting from salt remaining in the unsaturated zone or shallow groundwater that finally discharged to streams. Most of the increase in specific conductance between upstream and downstream sites probably resulted from deicing salts carried in stormwater washed from I-95 highway lanes, ramps, access roads (table 4); other State or town roads; parking lots; sidewalks; and driveways. Specific conductance at upstream monitoring sites generally showed less of an increase than at downstream monitoring sites during precipitation and melting events as a result of dilution. Some upstream monitoring sites, however, including Jordan Brook and Stony Brook, had increased specific conductance during these events because large parking lots and highway drainage, respectively, contributed to water upstream from the sites. However, the extent of impervious area, which was estimated by using the 2010 land cover (University of Connecticut, 2010) and the ISAT tool, corresponded to the specific conductance response (Brown and others, 2011). Some stormwater from parts of I-95 drains through culverts to the watershed of the upstream monitoring site, such as in the Stony Brook watershed.
Table 10. Storm characteristics, weather data, and peak chloride concentrations and loads related to deicing and melting events for upstream and downstream monitoring sites at Four Mile River, Oil Mill Brook, Stony Brook, and Jordan Brook, southeastern Connecticut, from November 2008 to September 2011.

[Available separately at http://dx.doi.org/10.3133/sir20155057]

During the spring and summer months, specific conductance in continuous measurements and $\mathrm{Cl}^{-}$concentrations in samples generally decreased in response to precipitation events and subsequent increases in streamflow. According to ConnDOT records, no road deicers were applied to State roads after March 2, 2009, during the 2008-09 winter; after February 27, 2010, during the 2009-10 winter; and after April 1, 2011, during the 2010-11 winter (table 5). The continued increase in specific conductance and estimated $\mathrm{Cl}^{-}$ concentrations with increased stormflow at some sites after these dates, when daily mean temperatures exceeded $0{ }^{\circ} \mathrm{C}$ and all snow had melted, indicates that high concentrations of $\mathrm{Cl}^{-}$ and other deicing constituents were retained in soils and (or) shallow groundwater and continued to affect stream chemistry through the early part of the spring.

\section{Four Mile River}

The Four Mile River downstream site south of I-95 represents drainage from this two-lane interstate highway and the entrance and exit ramps in a predominantly forested area with 9 to 11 percent developed land (fig. 11). The areas of the contributing drainage basins for the upstream and downstream sites are 5.75 and $5.98 \mathrm{mi}^{2}$, respectively (table 1). The section of I-95 that crosses the watershed includes two interchanges with on and off ramps, and the cloverleaf for I-95 north to Four Mile Road acts as a low-lying area that can collect stormwater. Direct highway drainage inputs include one in the upstream watershed along southbound I-95 and one location in the downstream watershed at the beginning of the exit ramp from I-95 (fig. 11). An inactive mixed-waste landfill and an inactive septic lagoon are located about $0.1 \mathrm{mi}$ north of the upstream site and 0.36 mi north of the downstream site. The Old Lyme landfill has stopped accepting public waste but has not completed closure. The piezometer ELY 82 is located $0.1 \mathrm{mi}$ south of I-95 and about $200 \mathrm{ft}$ north of the downstream site.

Water-quality data for the Four Mile River upstream and downstream sites were recorded continuously from January 12,2009 , through the end of the study period, September 30, 2011. Median specific conductance and estimated $\mathrm{Cl}^{-}$concentrations were slightly higher at the downstream site than at the upstream site throughout the study period (fig. 4; table 9A). During winter months, specific conductance and estimated $\mathrm{Cl}^{-}$ concentrations at the downstream site increased in response to several deicing events - most notably during winter storm S7 on January 7, 2009, and winter storm S2 on December 9, 2009, when estimated $\mathrm{Cl}^{-}$concentrations exceeded $100 \mathrm{mg} / \mathrm{L}$ (fig. 4; table 10). Estimated $\mathrm{Cl}^{-}$concentrations did not reach $100 \mathrm{mg} / \mathrm{L}$ 


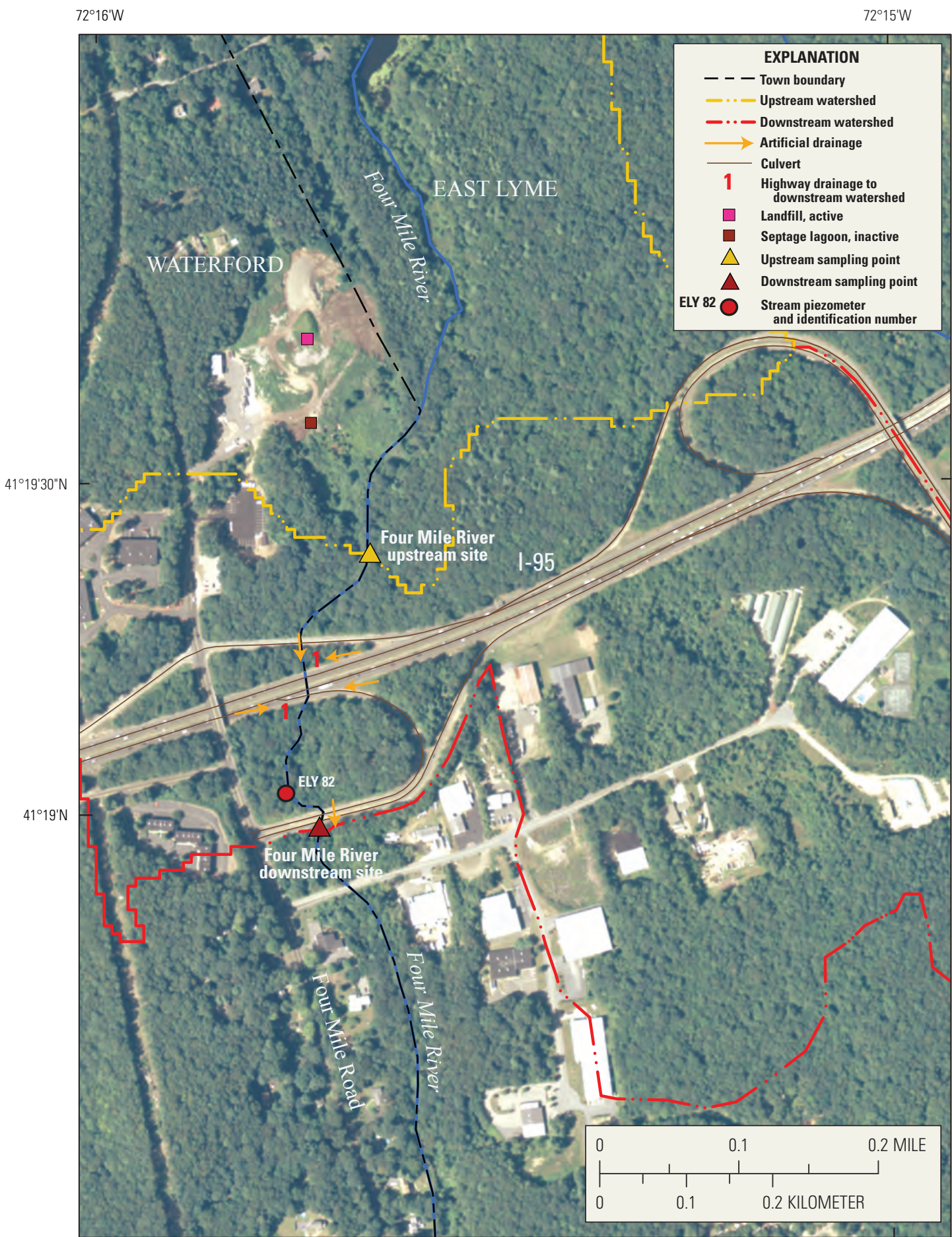

Base from Connecticut Department of Environmental Protection, 1994, 1:24,000

Projection: Connecticut State Plane Feet

Landfill sites from Connecticut Department of Environmental Protection, Bureau of Water Management, 1995

Figure 11. Watershed boundaries, drainage features, landfill and septic sources, water-quality monitoring sites, and the downstream streamgage at Four Mile River, southeastern Connecticut. 
during the 2010-11 winter season, although 5 peaks exceeded $40 \mathrm{mg} / \mathrm{L}$ during storms S7 and S11 (January 11, 2010, and February 1, 2011, respectively), activity A4 (February 7, 2011), and melting event M9 (January 11, 2011). The estimated amount of salt applied to I-95 and associated roads in the Four Mile River area indicates that, although the date and amount of deicers applied to State roads correspond to increases in specific conductance in some cases (fig. 4; table 5), the response in stream chemistry better relates to the cumulative amount and period of deicer application, in addition to the occurrence of rain and (or) warm temperatures and subsequent melting that washes deicers into the stream. For example, storms S4 and S5, which represent the first winter storms during the recording of data at the Four Mile River downstream site in 2009, resulted in increased levels of specific conductance and estimated $\mathrm{Cl}^{-}$concentrations in the stream (fig. 4). However, deicers applied during storm S6 in December 31, 2008, which consisted of several inches of snow with cold temperatures (less than $8^{\circ} \mathrm{C}$ ) and no rain, and activities 2 and 3 did not lead to any observed response in specific conductance at the Four Mile River downstream site (fig. 4), most likely because of the subfreezing temperatures and absence of rain or melting and subsequent runoff. Storm S7 consisted of snow followed by rain and resulted in the highest specific conductance $(527 \mu \mathrm{S} / \mathrm{cm})$ and estimated $\mathrm{Cl}^{-}$concentration $(160 \mathrm{mg} / \mathrm{L})$ during winter for this site (fig. 4; table 10). An estimated 17 tons of $\mathrm{Cl}^{-}$was applied to I-95 and associated State roadways (table 5) in the "frozen" period between the end of storm S5 on December 24, 2008, and the beginning of the increased levels of specific conductance on January 7, 2009, at 6:00 a.m., 14 hours into the deicer application. A similar cold period between storm S7 and storm S10 (January 27-29, 2009) had no increases in specific conductance or estimated $\mathrm{Cl}^{-}$concentrations in response to applications for storms S8 and S9. Finally, the period between storm S10 and storm S12, and the deicer applications in between, had no major increases in specific conductance, except during a rain event on February 12, 2009, when specific conductance reached $289 \mu \mathrm{S} / \mathrm{cm}$.

Specific conductance measured in samples collected at the downstream site during three events with extended subfreezing temperatures (maximum daily temperature below zero ${ }^{\circ} \mathrm{C}$ ) was higher than specific conductance measured by the continuous water-quality monitor (figs. $4 A$ and $B$ ). These events include a deicing activity on January 17, 2010 (A4), and winter storms on February 16, 2010 (S10), and January 18, 2011 (S7). The likely reason for these discrepancies is that the continuous monitor was partly frozen in the ice and was not in contact with the flowing part of the stream. The grab samples were collected by the automated sampler, which was drawing water from below the ice, in the flowing part of the stream.

\section{Oil Mill Brook}

The Oil Mill Brook site downstream from I-95 represents drainage from this four-lane interstate highway in a predominantly forested area with about 13 percent developed land use (fig. 12). The contributing drainage basins for the upstream and downstream stations are 5.37 and $5.67 \mathrm{mi}^{2}$, respectively.
The upstream watershed includes drainage from I-395 as well as Route 85, which are maintained by ConnDOT (figs. 1 and 12). The downstream watershed includes drainage from I-95 and an associated off ramp and deceleration lane, and drainage from I-395 (fig. 12).

Water-quality data for the Oil Mill Brook upstream and downstream sites were recorded continuously beginning December 17, 2008, through the end of the study period on September 30, 2011. Specific conductance and estimated $\mathrm{Cl}^{-}$ concentrations were higher at the downstream site for most of the study, except during base-flow conditions in the summer and early fall of each year when values at the upstream site became slightly higher (fig. 5; appendix 3).

Specific conductance and estimated $\mathrm{Cl}^{-}$concentrations increased at Oil Mill Brook upstream and downstream sites in response to several winter events and increased streamflow. $\mathrm{Cl}^{-}$concentrations were at or exceeded $100 \mathrm{mg} / \mathrm{L}$ during S7 and S10 during 2008-9, S2 and A2 during 2009-10, and S7 and S11 during 2010-11 (table 10; appendix 3). At the downstream site, stormwater runoff from a local road and bridge was observed to flow into the stream near the monitor and may have affected specific conductance and estimated $\mathrm{Cl}^{-}$concentrations during snowmelt.

Peaks in estimated $\mathrm{Cl}^{-}$concentrations also were observed during the spring and summer (fig. 5; appendix 3), likely in part from $\mathrm{Cl}^{-}$in deicers. For example, $\mathrm{Cl}^{-}$concentrations peaked in response to summer storms in 2010, apparently resulting from high concentrations in base flow. $\mathrm{Cl}^{-}$concentrations at the downstream site reached $21 \mathrm{mg} / \mathrm{L}$ on August 23, 2010, at 9:40 a.m. after a rain event in which streamflow had peaked 11 hours earlier in response to a 0.92 -in. rain event. $\mathrm{Cl}^{-}$concentrations reached $18 \mathrm{mg} / \mathrm{L}$ on September 4, 2010, at 9:20 a.m., 12 hours after streamflow had peaked at $39 \mathrm{ft}^{3} / \mathrm{s}$ on September 3 in response to a 1.57 -in. rain event. These lag periods could have been caused by Lake Konomoc, a reservoir retained by a dam with constant outflow, several miles upstream from I-95 (fig. 1).

\section{Stony Brook}

The Stony Brook site downstream from I-95 represents drainage from this two-lane interstate highway in an area with about 19 percent developed land use (fig. 13). Stony Brook is the smallest of the watersheds studied, and the contributing drainage basins for the upstream and downstream stations are 1.00 and $1.90 \mathrm{mi}^{2}$, respectively. A closed, bulky-waste landfill is located $0.4 \mathrm{mi}$ northeast of the upstream site (fig. 13). The highway and crossroads are highly modified, and drainage is complex; for example, an area in the downstream watershed drains to the north into the upstream watershed (fig. 13). In the beginning of the study, drainage from southbound I-95, just to the west of Stony Brook, flowed through a culvert (drainage 2 in fig. 13) to a location near the upstream site. The upstream site also received ephemeral drainage from a parking lot of an industrial complex to the east and a wooded area to the west; because of these poorly mixed sources, the upstream site was moved $100 \mathrm{ft}$ upstream from its original location 
on September 15, 2010 (fig. 13). The difference in specific conductance between the old and new water-quality monitor locations appears to be negligible (fig. 6).

Water-quality data for Stony Brook were recorded continuously from January 6, 2009, at the downstream site and from February 2, 2009, at the upstream site to the end of the study period (fig. 6; appendix 4); however, specific conductance and estimated $\mathrm{Cl}^{-}$concentration data for the upstream site are missing for several periods because of equipment failure, as discussed in the "Methods of Data Collection and Analysis" section. Median specific conductance and estimated $\mathrm{Cl}^{-}$concentrations generally were slightly higher at the downstream site than at the upstream site through the study period (table 9A; appendix 4). Specific conductance was elevated above the background of $150 \mu \mathrm{S} / \mathrm{cm}$ at the Stony Brook downstream site during discharge events associated with winter storms and other deicing activities. Specific conductance and estimated $\mathrm{Cl}^{-}$concentrations in the late winter/early spring months, however, generally decreased during discharge events because of dilution by runoff from precipitation, which contains lower concentrations of ions compared to base flow (fig. 6). Specific conductance and estimated $\mathrm{Cl}^{-}$concentrations generally were slightly higher at the Stony Brook downstream site than at the upstream site throughout the period of record, but there were exceptions. Specific conductance was higher at the upstream site during base-flow conditions in 2010 than at the downstream site. In addition, the upstream site showed increased specific conductance and estimated $\mathrm{Cl}^{-}$concentrations during two events because some highway drainage temporarily contributed to water upstream from the sites. Some stormwater from parts of I-95 drained through culverts to the watershed for the upstream monitoring site before it was moved in 2010, as explained previously in this section. During February 15-18, 2009, for example, elevated levels of specific conductance might have resulted from melting of remaining snow near I-95 or other upstream roads; as discussed previously, some drainage from I-95 flows to the north and likely affected the upstream site water-quality monitor before it was moved $50 \mathrm{ft}$ upstream (fig. 13). The upstream and downstream sites are $0.84 \mathrm{mi}$ apart, more than twice as far as any of the other site pairs (table 1); therefore, another possible cause for this discrepancy could be dilution from groundwater and (or) stormwater runoff between the upstream and downstream sites that acted to dampen the increase at the downstream site.

In the spring, $\mathrm{Cl}^{-}$concentrations at the downstream site above the background of about $29 \mathrm{mg} / \mathrm{L}$ were associated with rain events or warm air temperatures. These elevated concentrations likely resulted from salts in melting snow piles and (or) deicing salts that were flushed from soils and shallow groundwater, then discharged downstream. These peaks can be identified in table 10 by the "M," followed by the sequential number in the "Deicing or melting event" column. Studies have reported that a substantial percentage ( 45 to 85 percent) of $\mathrm{Cl}^{-}$in deicers is not removed by overland flow but infiltrates into soils and (or) groundwater (Howard and Haynes; 1993; Church and Friez, 1993; Toler and Pollock; 1974).
During spring or summer months, specific conductance was higher at the upstream site than at the downstream site on some occasions. The reason for the increase at the upstream site is not known, but the absence of an increase in specific conductance at the downstream site could result from dilution by stormwater or groundwater discharge between the upstream and downstream sites.

\section{Jordan Brook}

The Jordan Brook site downstream from I-95 represents drainage from this two-lane interstate highway in an area with about 32 percent developed land use (figs. 2 and 14). The contributing drainage basins for the upstream and downstream sites are 2.76 and $2.89 \mathrm{mi}^{2}$, respectively. Upstream and downstream sites receive drainage from several large retail stores and a shopping mall (figs. 1 and 14). The upstream site is $0.16 \mathrm{mi}$ from a large parking lot and the site of a closed, mixed-waste landfill, and 0.43 miles southwest (downstream) of a large shopping mall. The downstream site is $0.32 \mathrm{mi}$ downstream from the upstream site and $0.25 \mathrm{mi}$ south of I-95, so drainage from the upstream watershed undergoes some dilution before reaching the downstream site (fig. 14).

Water-quality data for Jordan Brook upstream and downstream sites were recorded continuously from February 5, 2009, through September 2011 (fig. 7; appendix 5). Specific conductance and estimated $\mathrm{Cl}^{-}$concentrations generally increased concurrently at the Jordan Brook upstream and downstream sites during winter and early spring high-discharge events associated with winter storms or deicing activities. The upstream and downstream watershed areas have similar percentages of impervious area. The highest measured specific conductance and estimated $\mathrm{Cl}^{-}$concentration were $841 \mu \mathrm{S} / \mathrm{cm}$ and $270 \mathrm{mg} / \mathrm{L}$, respectively, on February 8, 2011; these values were associated with warm temperatures and melting of snow (figs. 3 and 7). Specific conductance and estimated $\mathrm{Cl}^{-}$concentrations often were highest at the upstream site and probably relate to the large percentage of adjacent impervious area, relative to the downstream site, to which deicing chemicals were applied. The application of deicing chemicals to several large parking lots to the west of the upstream site during snow or ice events resulted in high concentrations of $\mathrm{Cl}^{-} \mathrm{Na}^{+}$, and other ions that were washed into Jordan Brook.

Increases in specific conductance and estimated $\mathrm{Cl}^{-}$concentrations at upstream and downstream sites during the late winter and early spring of each year probably resulted from delayed snowmelt. Increases in specific conductance at the upstream and downstream sites, typically in March and April, are associated with rain events and likely resulted from salts in melting snow piles and (or) $\mathrm{Cl}^{-}$and other ions in deicers that were flushed from soils and shallow groundwater, then discharged downstream (appendix 5). A similar effect was observed at the Stony Brook downstream site (appendix 4). After the winter deicing period ended, specific conductance and estimated $\mathrm{Cl}^{-}$concentrations in Jordan Brook decreased during precipitation and discharge events as a result of dilution (fig. 7; appendix 5). 


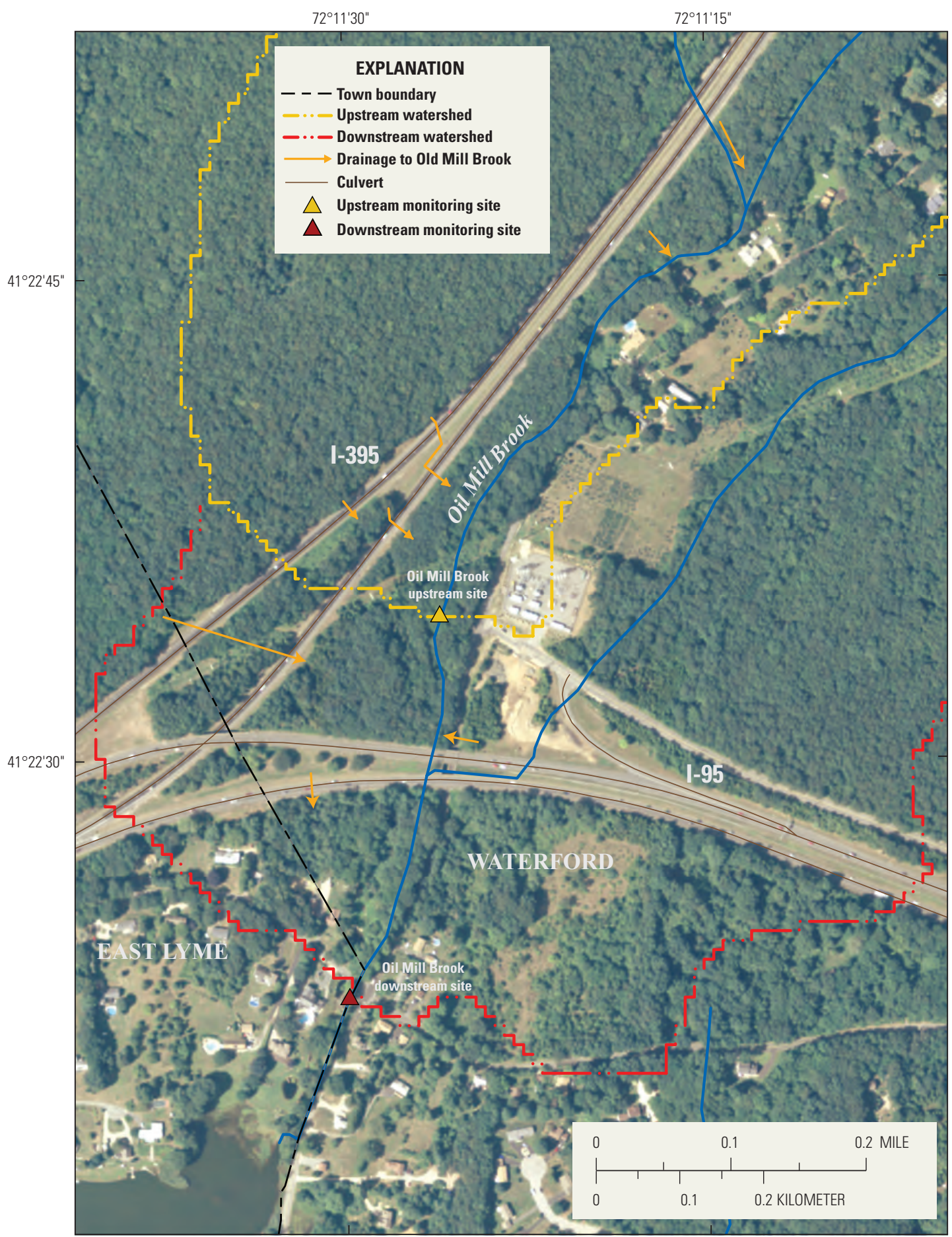

Base from Connecticut Department of Environmental

\section{Protection, 1994, 1:24,000}

Projection: Connecticut State Plane Feet

Figure 12. Watershed boundaries, drainage features, water-quality monitoring sites, and the downstream streamgage at Oil Mill Brook, southeastern Connecticut. 
$72^{\circ} 11$

$72^{\circ} 10^{\prime}$

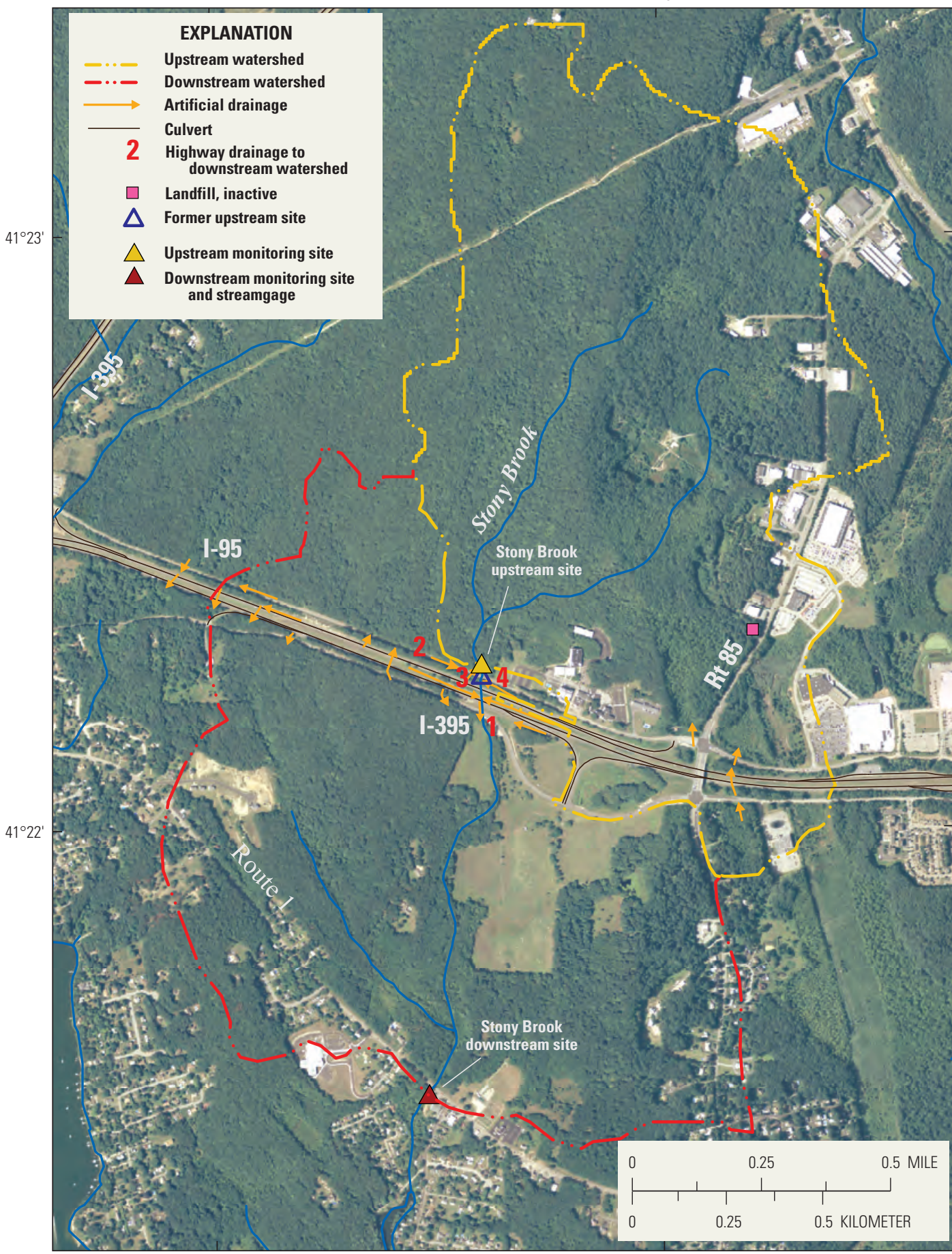

Base from Connecticut Department of Environmental

Landfills from Connecticut Department of Environmental Protection, 1994, 1:24,000

Protection, Bureau of Water Management, 1995

Projection: Connecticut State Plane Feet

Figure 13. Watershed boundaries, drainage features, landfill sources, water-quality monitoring sites, and the downstream streamgage at Stony Brook, southeastern Connecticut. 


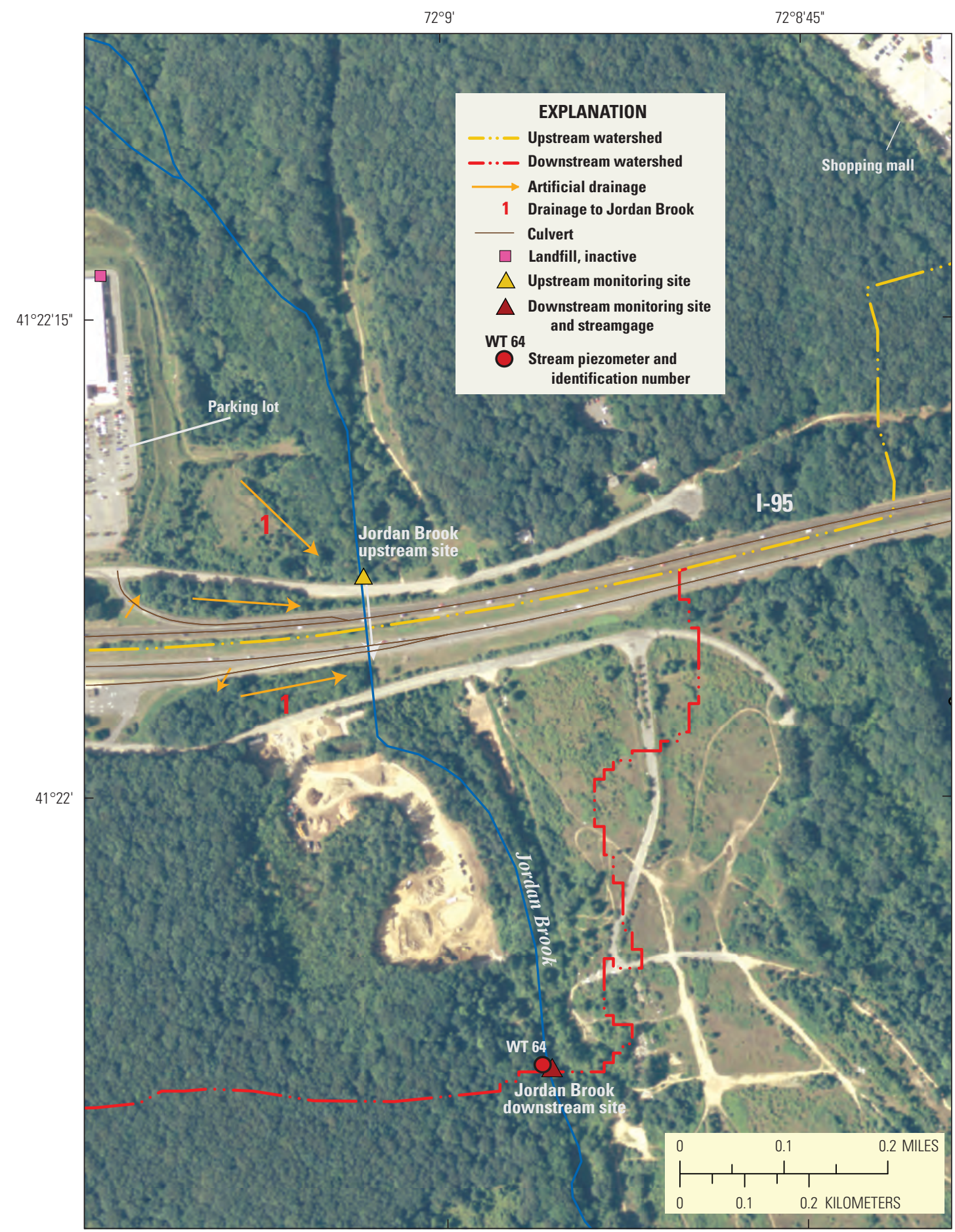

Base from Connecticut Department of Environmental Protection, 1994, 1:24,000

Landfills from Connecticut Department of Environmental Projection: Connecticut State Plane Feet

Figure 14. Watershed boundaries, drainage features, landfill sources, water-quality monitoring sites, and the downstream streamgage at Jordan Brook, southeastern Connecticut. 
Specific conductance and estimated $\mathrm{Cl}^{-}$concentrations at both Jordan Brook sites were highest during the 2010-11 winter season and may have resulted from the larger amount of deicers applied compared to the previous two winters (table 5). $\mathrm{Cl}^{-}$concentrations at the other three downstream sites were not as high during the 2010-11 winter relative to the 2008-9 and 2009-10 winters; the difference might be explained by the large area of parking lots in the Jordan Brook watershed.

\section{Groundwater/Surface-Water Interaction}

The chemistry of groundwater samples from piezometers at Four Mile River and Jordan Brook sites was compared with the chemistry of streamwater samples at these sites to determine possible groundwater/surface-water interactions. At the Four Mile River piezometer site, concentrations of $\mathrm{Cl}^{-}$and other major ions were much higher (up to $800 \mathrm{mg} / \mathrm{L} \mathrm{Cl}$ ) in the groundwater samples than streamwater samples (fig. 15A). The high concentrations in groundwater were observed throughout the year and could result from leachate contamination from a former landfill and associated septage lagoon to the north (fig. 11). Concentrations of barium (Ba) and strontium ( $\mathrm{Sr}$ ) also were much higher in the Four Mile River piezometer ELY82 water than in the streamwater, or in what is typical of groundwater quality in Connecticut (appendix 1); $\mathrm{Ba}$ and $\mathrm{Sr}$ concentrations are commonly high in landfill leachate (Mirecki and Parks, 1994) and septic leachate (Brown and others, 2009). Although there appeared to be little interaction with streamwater at the downstream site, the high concentrations of $\mathrm{Cl}^{-}$in groundwater might be a concern for the quality of streamwater, and the possible exceedance of the aquatic criteria, farther downstream. At the Jordan Brook piezometer site, concentrations of $\mathrm{Cl}^{-}$and other major ions were lower in groundwater samples than in streamwater samples, probably reflecting the absence of contamination within the small contributing recharge area for this groundwater (fig. 15). The generalized cross section (fig. 15) shows the vertical difference in major ion chemistry between streamwater and groundwater.

Concentrations of chloride in relation to chloride/bromide mass concentration ratios were plotted to help determine the sources of $\mathrm{Cl}^{-}$to the streamwater samples and groundwater samples from the piezometers. Concentrations of $\mathrm{Cl}^{-}$and $\mathrm{Br}$ are useful in distinguishing several sources because of their conservative nature in water and different abundances in natural fluids and most solids (Davis and others, 1998); also, natural halite deposits are nonexistent in the study area and adjacent bedrock. Plots of $\mathrm{Cl}^{-}$concentrations and $\mathrm{Cl} / \mathrm{Br}$ ratios have been used to help determine the effects of road salt, sewage, and seawater or brines on groundwater quality (Davis and others, 1998; Vengosh and Pankratov, 1998; Panno and others, 2006; Mullaney and others, 2009). Atmospheric deposition is the primary source of $\mathrm{Cl}^{-}$and $\mathrm{Br}^{-}$in pristine groundwater in the study area. $\mathrm{Cl} / \mathrm{Br}$ ratios in precipitation typically range from 50 to 100; near the coast, ratios generally are about 290, similar to seawater, and decrease with distance from the ocean to a low of from 20 to 56 in the midwestern United States
(Panno and others, 2006). Seawater has an average $\mathrm{Cl}^{-}$concentration of about 19,500 mg/L and an average $\mathrm{Br}$ concentration of about $290 \mathrm{mg} / \mathrm{L}$ (Davis and others, 1998). A plot of $\mathrm{Cl}^{-}$concentrations and $\mathrm{Cl} / \mathrm{Br}$ mass ratios shows the distribution in streamwater and piezometer groundwater samples relative to previously published source values or ranges for road salt (halite), domestic sewage leachate, and landfill leachate (fig. 16). Mixing lines were calculated between assumed end points for dilute groundwater and halite, domestic sewage leachate, and landfill leachate. Halite is the primary source of deicer salts, but $\mathrm{CaCl}_{2}, \mathrm{MgCl}_{2}$, and distillers condensed solubles are used on driveways, parking lots, and town roads and have a range of $\mathrm{Cl} / \mathrm{Br}$ mass ratios but overall are similar to halite (Mullaney and others, 2009; Panno and others, 2006). The more conservative nature of $\mathrm{Br}^{-}$compared to $\mathrm{Cl}^{-}$also might affect the ratios in stormwater runoff or streams near State highways. A sample of highway runoff collected from a culvert at Stony Brook, for example, had a $\mathrm{Cl} / \mathrm{Br}$ ratio that plotted below the mixing line of halite and sewage.

$\mathrm{Cl}^{-}$concentrations and $\mathrm{Cl} / \mathrm{Br}$ ratios in the study area could be affected to some extent by four different sources or end members: dilute groundwater, halite, sewage (septic leachate), and landfill leachate (fig. 16). Most of the stream samples fall along the dilute water-halite mixing line and probably are affected by road deicers. $\mathrm{A} \mathrm{Cl} / \mathrm{Br}$ ratio $(5,000)$ that was representative of halite road salt in Massachusetts (Granato, 1996) and a $\mathrm{Cl}^{-}$concentration of $10,000 \mathrm{mg} / \mathrm{L}$ were used for the end point of halite. Piezometer samples that appeared to be affected by road-salt applications and by septic-tank drainfields had the largest deviation from dilute groundwater in the $\mathrm{Cl} / \mathrm{Br}$ plots. A median $\mathrm{Cl}^{-}$concentration of $69 \mathrm{mg} / \mathrm{L}$ and a $\mathrm{Cl} / \mathrm{Br}$ ratio of 460 , as determined for septic effluent from private septic systems in the midwestern United States (Thomas, 2000; Jagucki and Darner, 2001), were used to represent the end point for septic-system leachate (fig. 16). The landfill leachate end member is the median of 10 leachate samples from a study in Illinois (Panno and others, 2006). The location of samples on the plot between sewage and landfill leachate indicates that the source of $\mathrm{Cl}^{-}$and other ions could result from both sewage and landfill leachate.

\section{Chloride Loads and Yields}

Daily mean $\mathrm{Cl}^{-}$concentrations were estimated for the period of the study at each of the upstream and downstream sites. Daily mean load was estimated for each of the downstream sites (fig. 17A-D). The load is defined for this report as the $\mathrm{Cl}^{-}$mass per unit time, and the yield is defined as the $\mathrm{Cl}^{-}$ mass per unit area. The estimated daily mean $\mathrm{Cl}^{-}$concentration at downstream sites and instantaneous $\mathrm{Cl}^{-}$concentrations increased with streamflow (and stormwater runoff of road deicers) during most winter storms but decreased during the warmer months after deicer application had ended. Estimated daily loads, however, generally increased with streamflow and reflect the greater overall $\mathrm{Cl}^{-}$amounts that were transported despite the dilution that occurred. $\mathrm{Cl}^{-}$loads in streams generally were highest in the winter and early spring. $\mathrm{Cl}^{-}$loads were 

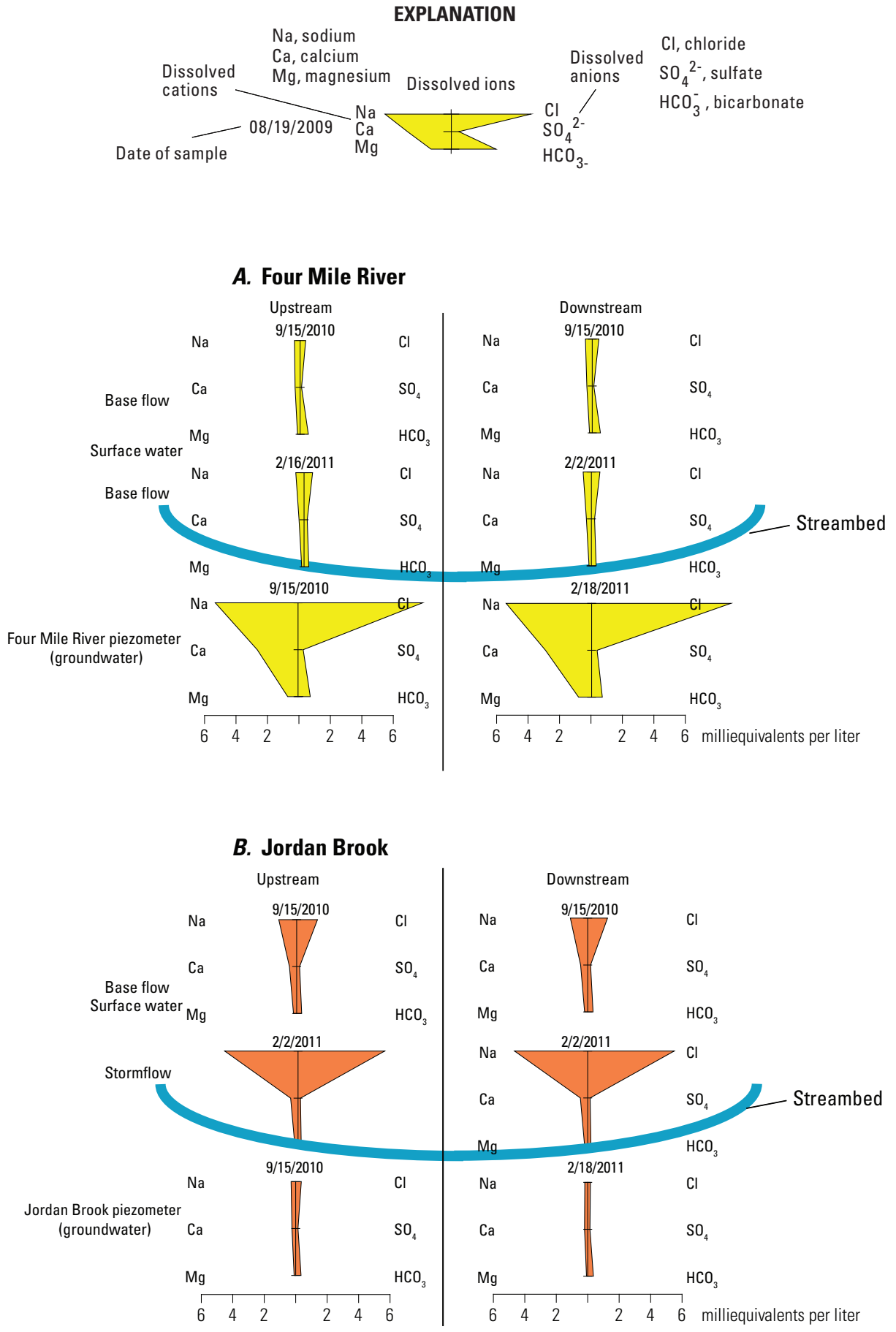

Figure 15. Concentrations of major ions in water from water-quality monitoring sites and stream piezometers in generalized cross section at $A$, Four Mile River and $B$, Jordan Brook, southeastern Connecticut, from September 2010 to February 2011. 
Factors That Affect Chloride Concentrations, Loads, and Yields

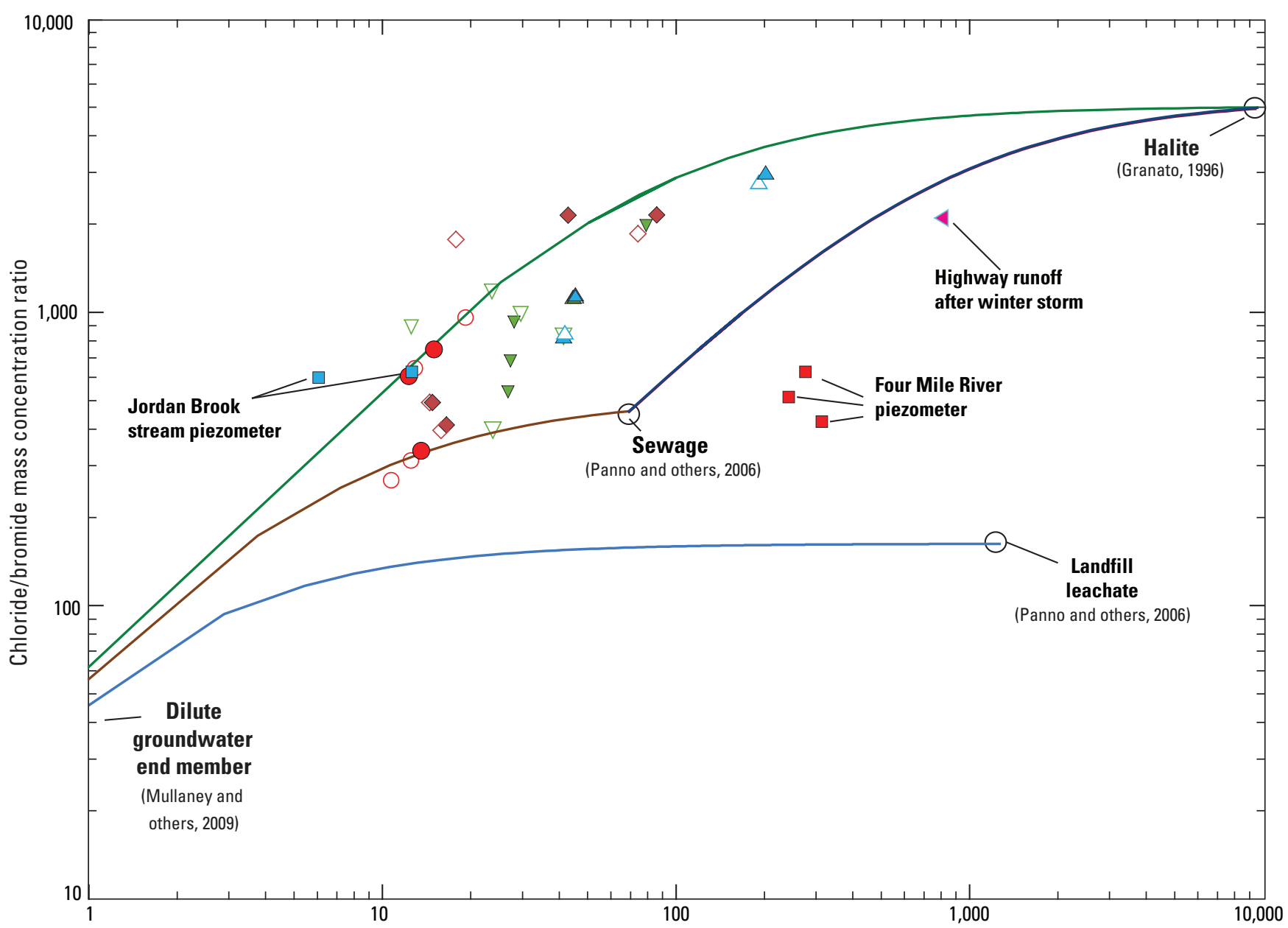

Chloride concentration, in milligrams per liter

\begin{tabular}{|c|c|c|c|c|}
\hline \multicolumn{5}{|c|}{ EXPLANATION } \\
\hline Mixing Lines & & stream sites & & ownstream sites \\
\hline Dilute groundwater-halite & 0 & Four Mile River & 0 & Four Mile River \\
\hline Sewage-halite & $\diamond$ & Oil Mill Brook & $\square$ & Four Mile River piezometer \\
\hline Dilute groundwater—sewage & $\nabla$ & Stony Brook & $\nabla$ & Oil Mill Brook \\
\hline Dilute groundwater—landfill & & Jordan Brook & $\nabla$ & $\begin{array}{l}\text { Stony Brook } \\
\text { Jordan Brook }\end{array}$ \\
\hline Mixing end member & & & & Jordan Brook piezometer \\
\hline
\end{tabular}

Figure 16. Concentrations of chloride in relation to chloride/bromide mass concentration ratios in samples collected in the study area, southeastern Connecticut, together with mixing lines between designated end members for dilute groundwater, halite, sewage, and landfill leachate. 

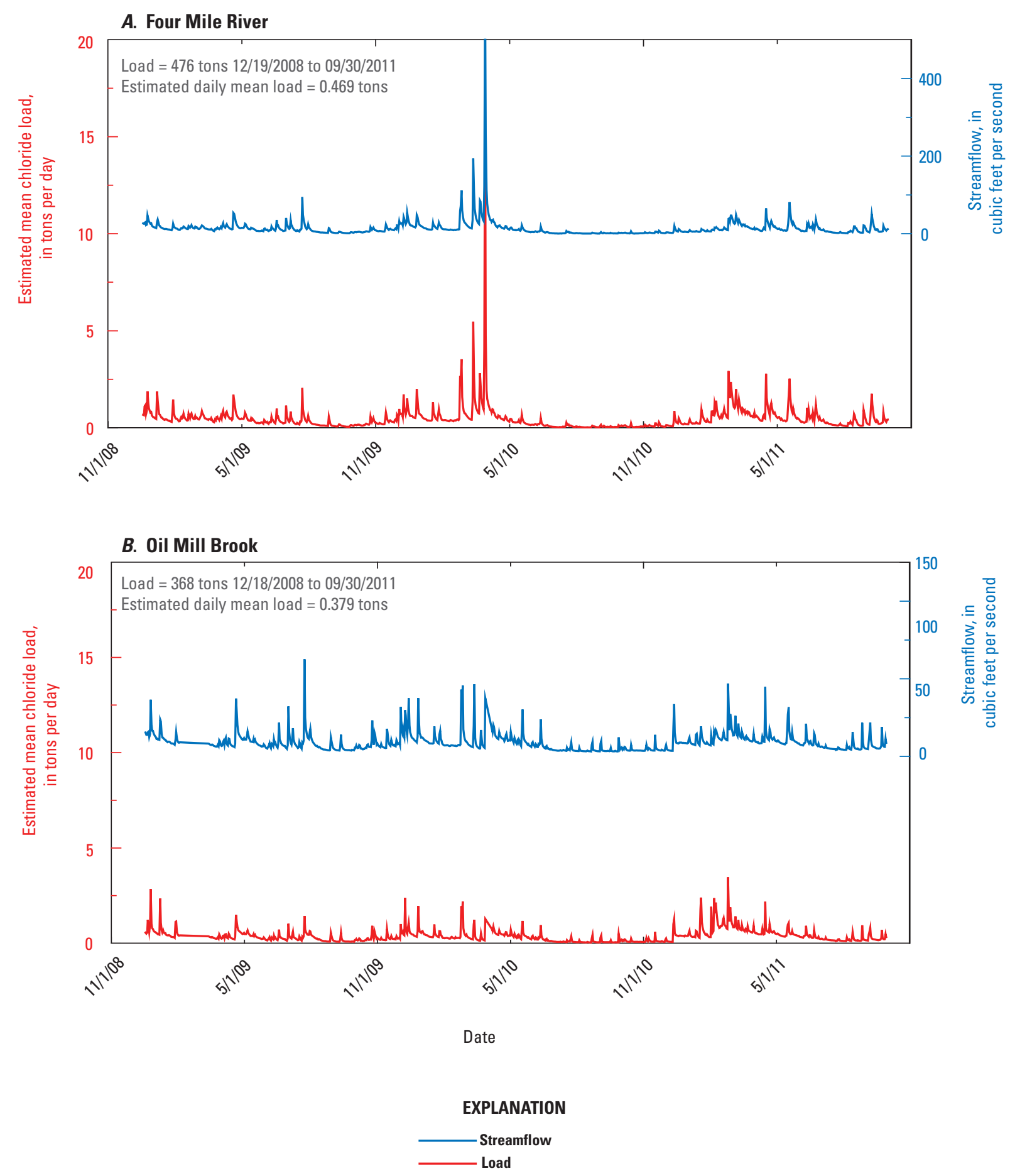

Figure 17. Estimated daily mean chloride load at the $A$, Four Mile River, $B$, Oil Mill Brook, $C$, Stony Brook, and $D$, Jordan Brook downstream sites, southeastern Connecticut, from November 2008 to September 2011. 

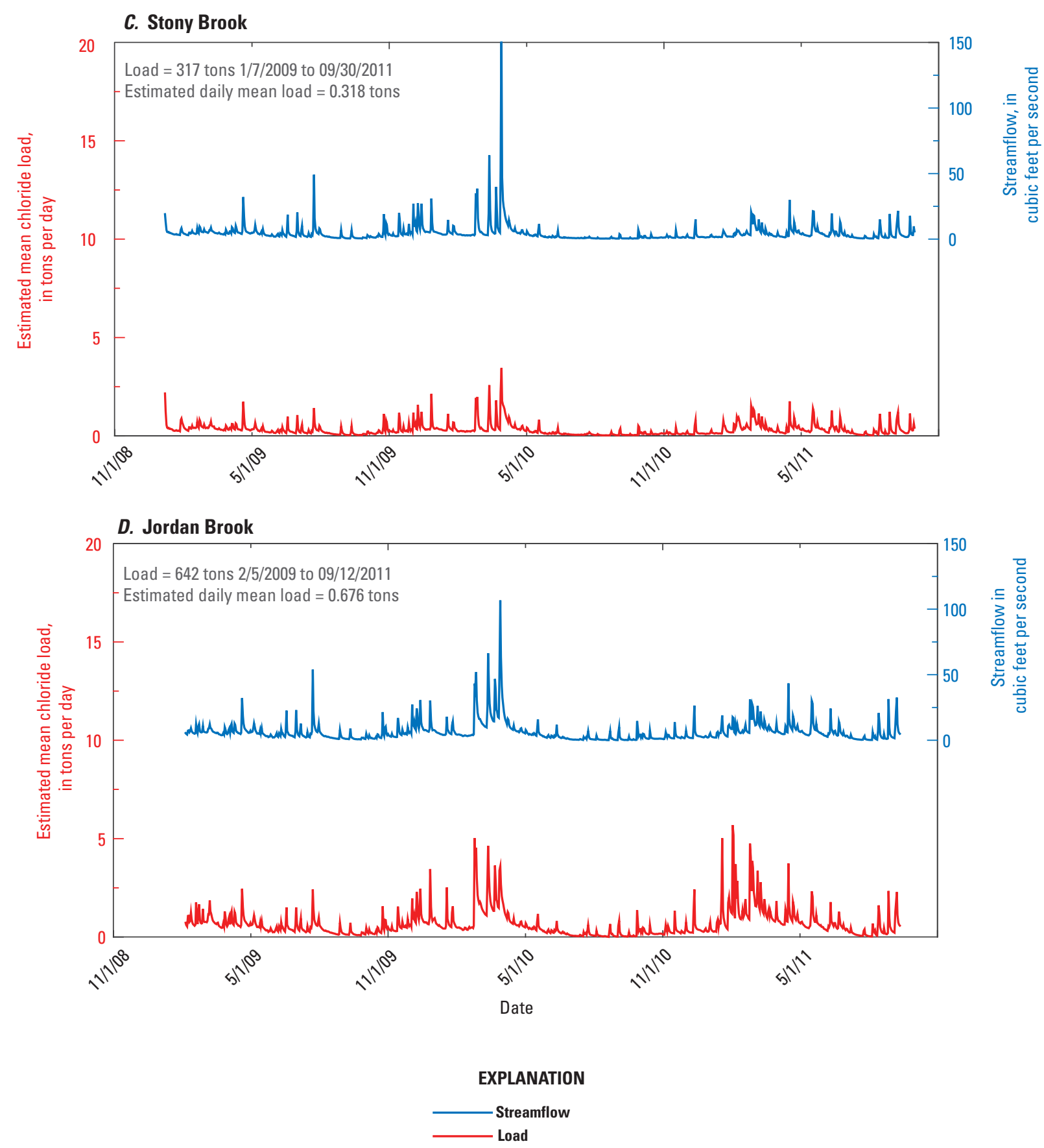

Figure 17. Estimated daily mean chloride load at the $A$, Four Mile River, B, Oil Mill Brook, $C$, Stony Brook, and D, Jordan Brook downstream sites, southeastern Connecticut, from November 2008 to September 2011.—Continued 
lower in the Four Mile River and Stony Brook watersheds in the third year (2010-11) than in the second year (2009-10), despite the higher amounts of deicers used by ConnDOT; this might result from lower rainfall during this third year and, therefore, less atmospheric $\mathrm{Cl}^{-}$sources and less water to carry away the deicing salts.

Estimated annual $\mathrm{Cl}^{-}$yields for the four monitoring sites downstream from I-95 during the period of streamflow record ranged from 16.5 tons per square mile (ton $/ \mathrm{mi}^{2}$ ) (93.6 tons total) at the Oil Mill Brook downstream site to $92.5 \mathrm{ton} / \mathrm{mi}^{2}$ (267 tons total) at the Jordan Brook downstream site (table 11). The estimated daily mean yield in the downstream sites ranged from $0.056\left[(\right.$ ton $\left.\left./ \mathrm{d}) / \mathrm{mi}^{2}\right)\right]$ for Oil Mill Brook, which had the highest percentage of forest and wetland area, to 0.27 [(ton $\left.\left./ \mathrm{d}) / \mathrm{mi}^{2}\right)\right]$ for Jordan Brook, which had the lowest percentage of forest and wetland area and the highest percentage of urban development (and impervious area). Previous analysis (Brown and others, 2011) indicated that $\mathrm{Cl}^{-}$yields for the sites were positively correlated with the percentage of impervious area, probably reflecting the application of deicers to roadways, as well as sources and practices associated with greater impervious area, such as wastewater and septic-system discharges, and leachate from landfills and salt-storage areas.

The estimated $\mathrm{Cl}^{-}$load from atmospheric deposition was based on concentrations measured at the NADP station at Abington, Conn. The contribution of $\mathrm{Cl}^{-}$load from atmospheric deposition to the total load in streamflow ranged from a 0.07 -percent contribution ( 0.16 tons) for the Jordan Brook downstream watershed to a 0.57 -percent contribution (0.78 tons) for the Oil Mill Brook downstream watershed (table 11B).

The $\mathrm{Cl}^{-}$loads in streams (outputs) were compared with $\mathrm{Cl}^{-}$ load inputs, including atmospheric deposition and deicer applications by ConnDOT and towns (table $11 B$ ). The $\mathrm{Cl}^{-}$load inputs

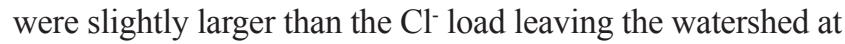
most of the sites, at least during most years. The net losses in $\mathrm{Cl}^{-}$from the watershed were less than 1 percent of $\mathrm{Cl}^{-}$inputs and are indicated by negative values in table $11 B$. The load balances for Four Mile River, Stony Brook, and Jordan Brook were mixed, depending on the year (table $11 B$ ). The $\mathrm{Cl}^{-}$load balances for the Four Mile River watershed ranged from a loss of 76 tons, or -0.42 percent, of the $\mathrm{Cl}^{-}$load leaving the watershed by the stream to a gain of 42 tons, or 0.25 percent (table 11B). The $\mathrm{Cl}^{-}$load inputs for the Oil Mill Brook watershed minus $\mathrm{Cl}^{-}$load leaving the watershed was 522 tons (3.8 percent). The percent contribution of $\mathrm{Cl}^{-}$input that is unaccounted for in the mass balance for the watershed areas could be related to the lag period between the application of deicers and $\mathrm{Cl}^{-}$concentrations observed in streams or retention of $\mathrm{Cl}^{-}$in the unsaturated zone from year to year. Furthermore, this assessment of load balance is only semiquantitative and does not include the $\mathrm{Cl}^{-}$ load in groundwater leaving the study areas. Estimates of direct recharge of $\mathrm{Cl}^{-}$to groundwater that originates from atmospheric deposition, deicer applications, septic-tank drainfields, and others sources were not within the scope of this project.

\section{Peak Chloride Concentrations During Winter Storms}

The factors that affect peak $\mathrm{Cl}^{-}$concentrations during winter storms can be grouped into (1) watershed characteristics and (2) characteristics related to road deicing, including winter storm characteristics (table 12). Watershed characteristics include size, shape, channel slope, drainage density, percentage of urban land use, impervious area, surficial geology, highway length, road or highway drains to streams, streamflow, and specific conductance or $\mathrm{Cl}^{-}$concentrations in base flow (table 12). Characteristics associated with deicing events include deicer type and the timing and duration of its application, and weather factors, such as existing snowpack, duration of antecedent subfreezing temperatures, air temperature, rainfall amount, and timing and duration of the winter storm (table 12). The duration of the specific conductance or $\mathrm{Cl}^{-}$concentration peak and the daily mean specific conductance and estimated $\mathrm{Cl}^{-}$concentration also are pertinent to deicing event characteristics and were used to help assess factors that affect $\mathrm{Cl}^{-}$concentrations in winter storms.

Peaks in specific conductance and estimated $\mathrm{Cl}^{-}$concentrations during winter months were related to the type of deicing, storm, and (or) melting event; the modeled snow pack; the storm or weather characteristics; the lag time between the beginning of the storm and the estimated peak $\mathrm{Cl}^{-}$concentration; and the daily mean streamflow (table 10). These factors were used to determine how $\mathrm{Cl}^{-}$concentrations might be predicted during future storms and in other watersheds. The storm or weather characteristics include the rainfall amount, the duration of the precipitation or melting event, the minimum and maximum air temperature, and the period of below-freezing temperatures preceding or following the event.

Based on the Kruskal-Wallis test, the peak specific conductance during winter storms was found to be significantly related to the watershed, the winter season, the type, duration, and amount of precipitation, the minimum air temperature, the base flow or daily mean specific conductance, the impervious cover, pre-existing snow pack, and the time of subfreezing conditions before a storm (table 8). The deicer $\mathrm{Cl}^{-}$for each deicing event also was found to be significantly related to the winter season, the type, duration, and amount of precipitation, and the time of subfreezing conditions before a storm.

Tukey's HSD test was used to further assess which categorical factors had a significantly different effect on peak specific conductance and the amount of deicer $\mathrm{Cl}^{-}$during winter storms (table $8 B$ ). Neither the peak specific conductance nor the amount of deicer $\mathrm{Cl}^{-}$were significantly different among watersheds or among the different winter seasons, but they were significantly different among the precipitation types.

The periods of deicing provided by ConnDOT are shown in tables 5 and 10, together with the types of event - either winter storms, S, of snow or frozen precipitation, or activities, $\mathrm{A}$, in response to slippery roads caused by non-storm-related ice or wind-blown snow. Other types include a melting event, during which no deicers were applied, either a rain- or warm 


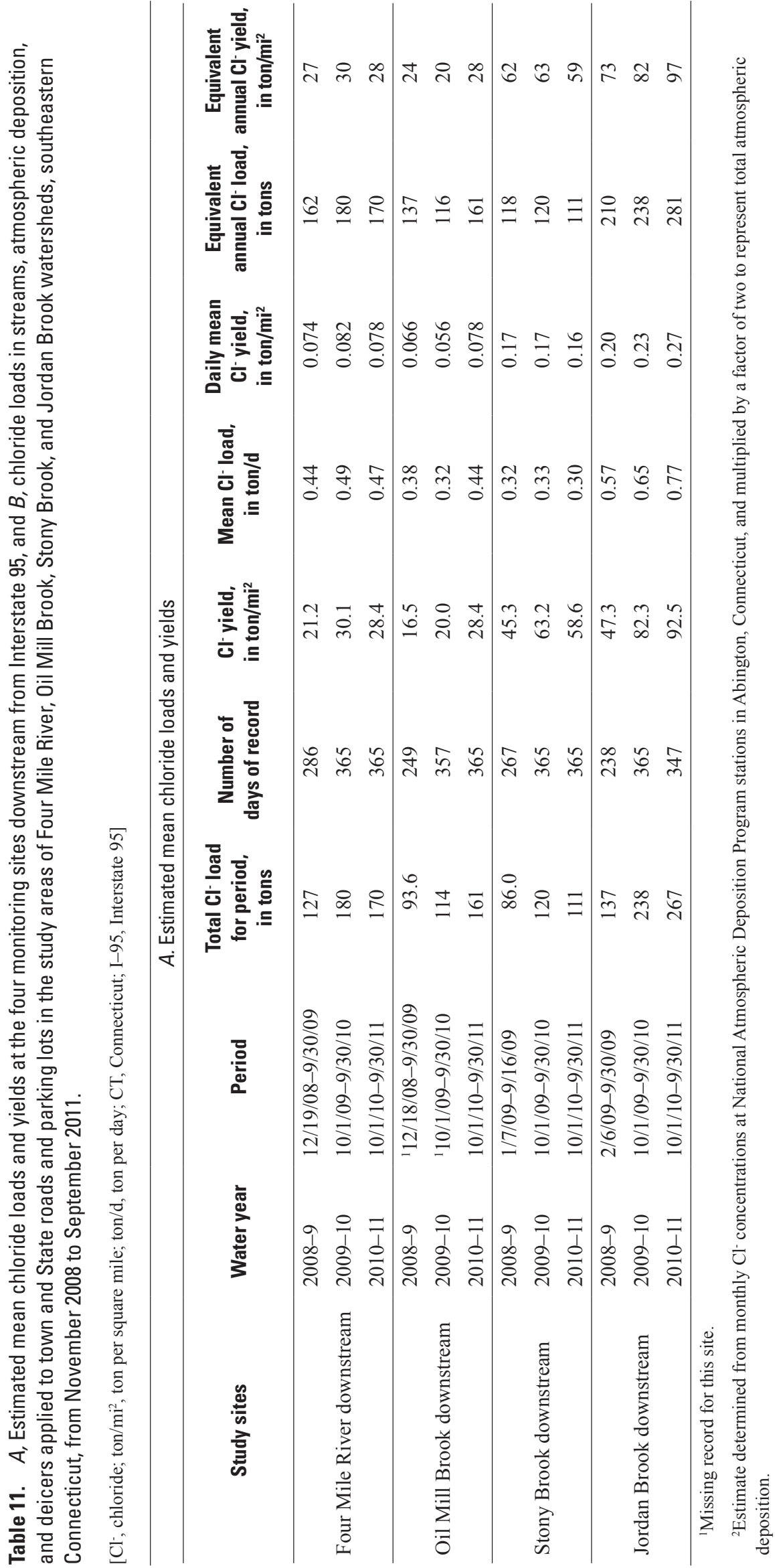


Table 11. A, Estimated mean chloride loads and yields at the four monitoring sites downstream from Interstate 95, and $B$, chloride loads in streams, Stony Brook, and Jordan Brook watersheds, southeastern Connecticut, from November 2008 to September 2011.—Continued

$\left[\mathrm{Cl}\right.$, chloride; ton $/ \mathrm{mi}^{2}$, ton per square mile; ton/d, ton per day; CT, Connecticut; I-95, Interstate 95]

B. Chloride Loads

\begin{tabular}{|c|c|c|c|c|c|c|c|c|}
\hline \multirow{3}{*}{ Study sites } & \multirow{3}{*}{$\begin{array}{c}\text { Water } \\
\text { year }\end{array}$} & \multicolumn{7}{|c|}{$\mathrm{Cl}^{-}$load, in tons } \\
\hline & & \multirow[b]{2}{*}{ Streams } & \multirow{2}{*}{$\begin{array}{l}\text { Atmospheric } \\
\text { deposition } \\
\text { Abington, } \mathrm{CT}^{2}\end{array}$} & \multicolumn{5}{|c|}{ Deicers } \\
\hline & & & & $\begin{array}{l}\text { State } \\
\text { roads }\end{array}$ & $\begin{array}{l}\text { State roads plus } \\
\text { hypothetical } \\
\text { added I-95 lane }\end{array}$ & $\begin{array}{l}\text { Town } \\
\text { roads }\end{array}$ & $\begin{array}{c}\text { Parking } \\
\text { lot/sidewalks } \\
\text { (30 percent of } \\
\text { road deicers) }\end{array}$ & $\begin{array}{c}\text { Total road, } \\
\text { parking lot, } \\
\text { sidewalk deicers }\end{array}$ \\
\hline \multirow{3}{*}{ Four Mile River downstream } & $2008-9$ & 162 & 0.82 & 89.8 & 101 & 60 & 45 & 194 \\
\hline & $2009-10$ & 180 & 0.33 & 38.2 & 42.9 & 41 & 24 & 103 \\
\hline & $2010-11$ & 170 & 0.45 & 95.7 & 108 & 67 & 49 & 212 \\
\hline \multirow{3}{*}{ Oil Mill Brook downstream } & $2008-9$ & 137 & 0.78 & 387 & 396 & 119 & 152 & 658 \\
\hline & $2009-10$ & 116 & 0.31 & 165 & 168 & 59 & 67 & 292 \\
\hline & $2010-11$ & 161 & 0.42 & 413 & 422 & 59 & 142 & 614 \\
\hline \multirow{3}{*}{ Stony Brook downstream } & $2008-9$ & 118 & 0.26 & 173 & 195 & 21 & 58 & 252 \\
\hline & $2009-10$ & 120 & 0.10 & 73.8 & 83.0 & 21 & 28 & 123 \\
\hline & $2010-11$ & 111 & 0.14 & 185 & 208 & 21 & 62 & 268 \\
\hline \multirow{3}{*}{ Jordan Brook downstream } & $2008-9$ & 210 & 0.40 & 242 & 256 & 77 & 96 & 414 \\
\hline & $2009-10$ & 238 & 0.16 & 103 & 109 & 77 & 54 & 233 \\
\hline & $2010-11$ & 281 & 0.22 & 258 & 273 & 77 & 100 & 435 \\
\hline
\end{tabular}

${ }^{1}$ Missing record for this site.

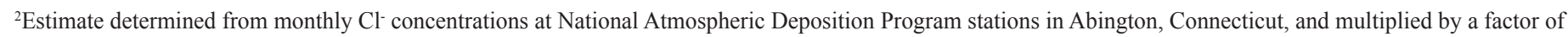
two to represent total atmospheric deposition. 
atmospheric deposition, and deicers applied to town and State roads and parking lots in the study areas of Four Mile River, Oil Mill Brook,

\begin{tabular}{|c|c|c|c|c|c|c|}
\hline \multirow{2}{*}{$\begin{array}{l}\text { Contribution of } \mathrm{Cl}^{-} \\
\text {in atmospheric } \\
\text { deposition }\end{array}$} & \multicolumn{2}{|c|}{$\begin{array}{l}\text { Contribution of } \mathrm{Cl}^{-} \text {in atmospheric } \\
\text { deposition and deicers }\end{array}$} & \multicolumn{4}{|c|}{$\begin{array}{l}\text { Contribution of } \mathrm{Cl}^{-} \text {inputs (atmospheric deposition and deicers) } \\
\text { minus outputs (streams) }\end{array}$} \\
\hline & $\begin{array}{l}\text { Without addition of } \\
\text { lane to I-95 }\end{array}$ & $\begin{array}{l}\text { With addition to } \\
\text { lane to I-95 }\end{array}$ & \multicolumn{2}{|c|}{ Without addition of lane to I-95 } & \multicolumn{2}{|c|}{ With addition of lane to I-95 } \\
\hline Percent & Tons & Tons & Tons & Percent & Tons & Percent \\
\hline 0.51 & 195 & 206 & 33 & 0.20 & 44 & 0.27 \\
\hline 0.18 & 104 & 108 & -76 & -0.42 & -72 & -0.40 \\
\hline 0.26 & 212 & 224 & 42 & 0.25 & 54 & 0.32 \\
\hline 0.57 & 659 & 668 & 522 & 3.8 & 531 & 3.87 \\
\hline 0.27 & 292 & 295 & 176 & 1.5 & 179 & 1.54 \\
\hline 0.26 & 614 & 623 & 453 & 2.8 & 462 & 2.87 \\
\hline 0.22 & 252 & 274 & 135 & 1.1 & 157 & 1.33 \\
\hline 0.09 & 123 & 132 & 3.1 & 0.03 & 12 & 0.10 \\
\hline 0.13 & 268 & 291 & 156 & 1.4 & 179 & 1.61 \\
\hline 0.19 & 415 & 429 & 205 & 0.98 & 219 & 1.04 \\
\hline 0.07 & 234 & 240 & -4.3 & -0.02 & 2 & 0.01 \\
\hline 0.08 & 435 & 450 & 154 & 0.55 & 169 & 0.60 \\
\hline
\end{tabular}


Table 12. Watershed and deicing event characteristics that affect specific conductance and chloride concentrations during winter deicing events.

[SC, specific conductance; $\mathrm{Cl}^{-}$, chloride concentration]

\begin{tabular}{ll}
\hline \multicolumn{1}{c}{ Watershed characteristics } & \multicolumn{1}{c}{ Deicing event characteristics } \\
\hline Watershed drainage area & Timing and duration of deicing \\
Watershed shape & Type of deicer \\
Drainage density & Type and duration of storm \\
Impervious area & Rainfall amount \\
Percent urban land use & Duration of SC or estimated $\mathrm{Cl}^{-}$peak \\
Highway length in watershed & Air temperature \\
Main channel slope & Existing snowpack \\
Base-flow SC or Cl- & Duration of antecedent subfreez- \\
concentration & ing temperatures \\
Surficial geology & Daily mean SC or $\mathrm{Cl}^{-}$ \\
Highway drains to stream & \\
Streamflow & \\
\hline
\end{tabular}

air temperatures-initiated melting of snow or ice, and postwinter peaks, which are estimated peaks of specific conductance or estimated $\mathrm{Cl}^{-}$concentrations in streams during flushing of shallow sediments or groundwater during the spring months (table 10). On some occasions, deicers were applied in anticipation of a snow or other frozen precipitation event, but only rain fell. Other categories, including the timing and duration of the actual storm or melting event, are provided in table 10 .

Peaks in specific conductance and estimated $\mathrm{Cl}^{-}$concentration varied with the type of winter storm or precipitation event and were highest during or after winter storms of the type "Frozen precipitation and rain" (fig. 18), in which the rain effectively washes off the deicers that were applied to melt the snow or ice. Estimated $\mathrm{Cl}^{-}$concentration peaks also were high during or after precipitation type "Rain after deicing," typically when $\mathrm{NaCl}$ brine was pre-applied to roads in anticipation of frozen precipitation that never occurred; the brine was instead washed off by rain (fig. 18). Estimated peak $\mathrm{Cl}^{-}$concentrations were not as high during or after a winter storm consisting of snow, freezing rain, or sleet.

Peaks in specific conductance and estimated $\mathrm{Cl}^{-}$concentration correlated positively with the duration of deicer application (fig. 19) but did not correlate with streamflow (fig. 20). Estimated $\mathrm{Cl}^{-}$concentration peaks correlated better with deicing time during "Frozen precipitation and rain" events and "Rain after deicing" events than during strictly "Frozen precipitation" events. The "Frozen precipitation and rain" events and "Rain after deicing" did correlate positively with the estimated $\mathrm{Cl}^{-}$ concentration peak. Specific conductance and estimated $\mathrm{Cl}^{-}$concentration peaks were highest when streamflows were less than about $30 \mathrm{ft}^{3} / \mathrm{s}$, with the exception of the Stony Brook site (fig. 20). The highest estimated $\mathrm{Cl}^{-}$concentration peaks at Jordan Brook were during events in which there was pre-existing snow on the ground (table 10) and possibly caused by the release of salt in snow piles associated with parking lots in the urbanized areas. Peaks in specific conductance and estimated $\mathrm{Cl}^{-}$concentration peaks during high streamflow were low at the Four Mile River site and likely were caused by dilution from rain with few contributions of ions from the predominantly forested watershed (fig. 4).

Air temperature also had an important effect on the melting and release of deicing salts from highways, roads, and parking lots. Specific conductance and estimated $\mathrm{Cl}^{-}$concentration peaks generally were highest when the minimum air temperature was between -8 and $3{ }^{\circ} \mathrm{C}$ (table 10), temperatures at which deicers are applied and at which melting is possible. Several high specific conductance peaks were preceded by an extended period of below-freezing air temperatures; a period of below-freezing temperatures after a deicing event can result in a delayed release of salt to the stream. Most of these peak occurrences involved "Frozen precipitation and rain" events, when previously applied deicers are finally flushed by rain or warmer air temperatures, including events on January 28, 2009 (91 hours), January 18, 2011 (32 hours), and February 1, 2011 (31 hours).

Watershed characteristics such as the percentage of impervious area had an important effect on specific conductance because deicers are applied to highways, roads, and parking lots. The watersheds with highest percentages of impervious area generally also had higher median and peak specific conductance and estimated $\mathrm{Cl}^{-}$concentrations (fig. 21; table 9).

\section{Relation of Estimated Peak Chloride Concentration to Explanatory Variables}

A multiple linear regression model was developed to describe the variability of the log of peak specific conductance or estimated peak $\mathrm{Cl}^{-}$concentrations. The dataset included characteristics of the watersheds (table 12), winter storms and timing of deicing events (table 10), and peaks of specific conductance or estimated $\mathrm{Cl}^{-}$concentration. Specific conductance is the primary explanatory variable used to estimate $\mathrm{Cl}^{-}$concentration. Continuous estimated $\mathrm{Cl}^{-}$concentrations are not always available in other studies, however, and continuous specific conductance can be used as a surrogate. Continuous specific conductance, therefore, was used as the response variable in the multiple linear regression model (table 13). Regression analysis was performed on data associated with 194 peaks of specific conductance at the four downstream sites. Five variables best explained the variability in the natural log of the specific conductance peak after deicing events: (1) snow on ground before deicing event (binary variable); (2) winter precipitation with rain (binary variable); (3) specific conductance in base flow; (4) interstate highway lane miles only divided by watershed area; and (5) amount of $\mathrm{Cl}^{-}$in deicers applied to State roads per lane mile. Model residuals were approximately normally distributed with a constant variance (fig. 22) and an adjusted $\mathrm{R}^{2}$ of 0.55 . Several variables, including watershed and deicing event characteristics (table 12) and estimated deicer amounts applied to town roads (table 11), did not improve the model. 


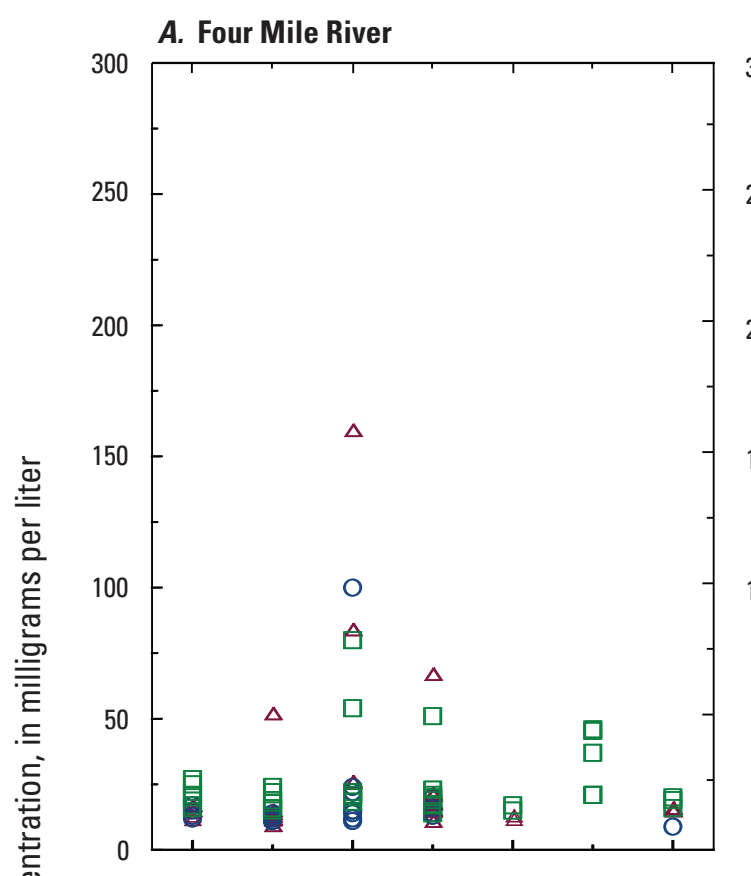

\section{B. Oil Mill Brook}

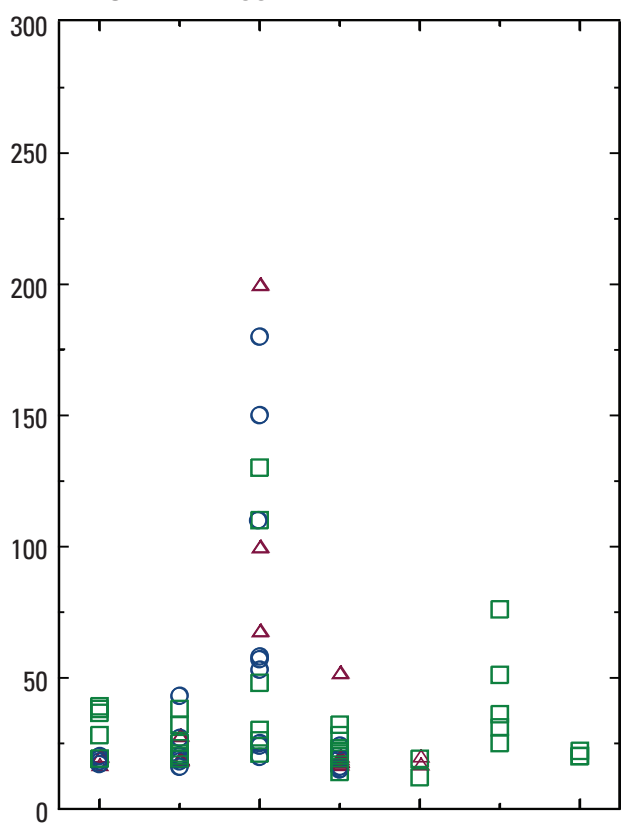

\section{Stony Brook}

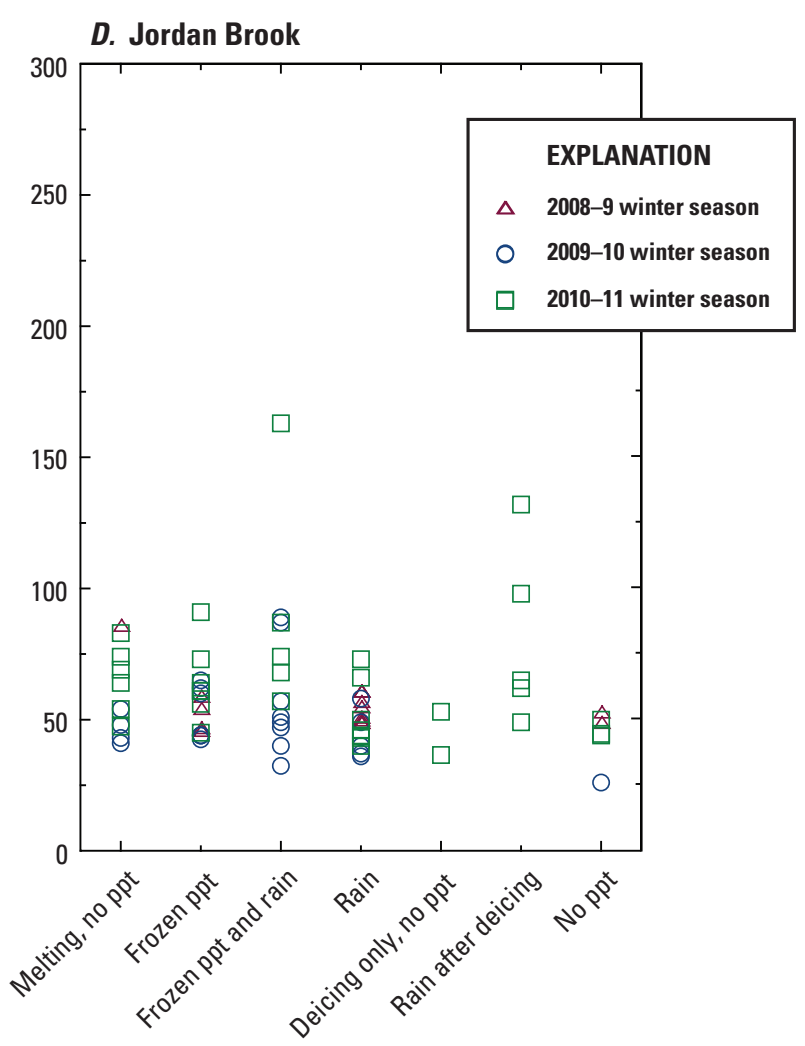

Precipitation type (ppt)

Figure 18. Estimated peak continuous chloride concentrations associated with different precipitation types at $A$, Four Mile River, B, Oil Mill Brook, C, Stony Brook, and D, Jordan Brook downstream sites, southeastern Connecticut, from November 2008 to September 2011. ppt, precipitation. 


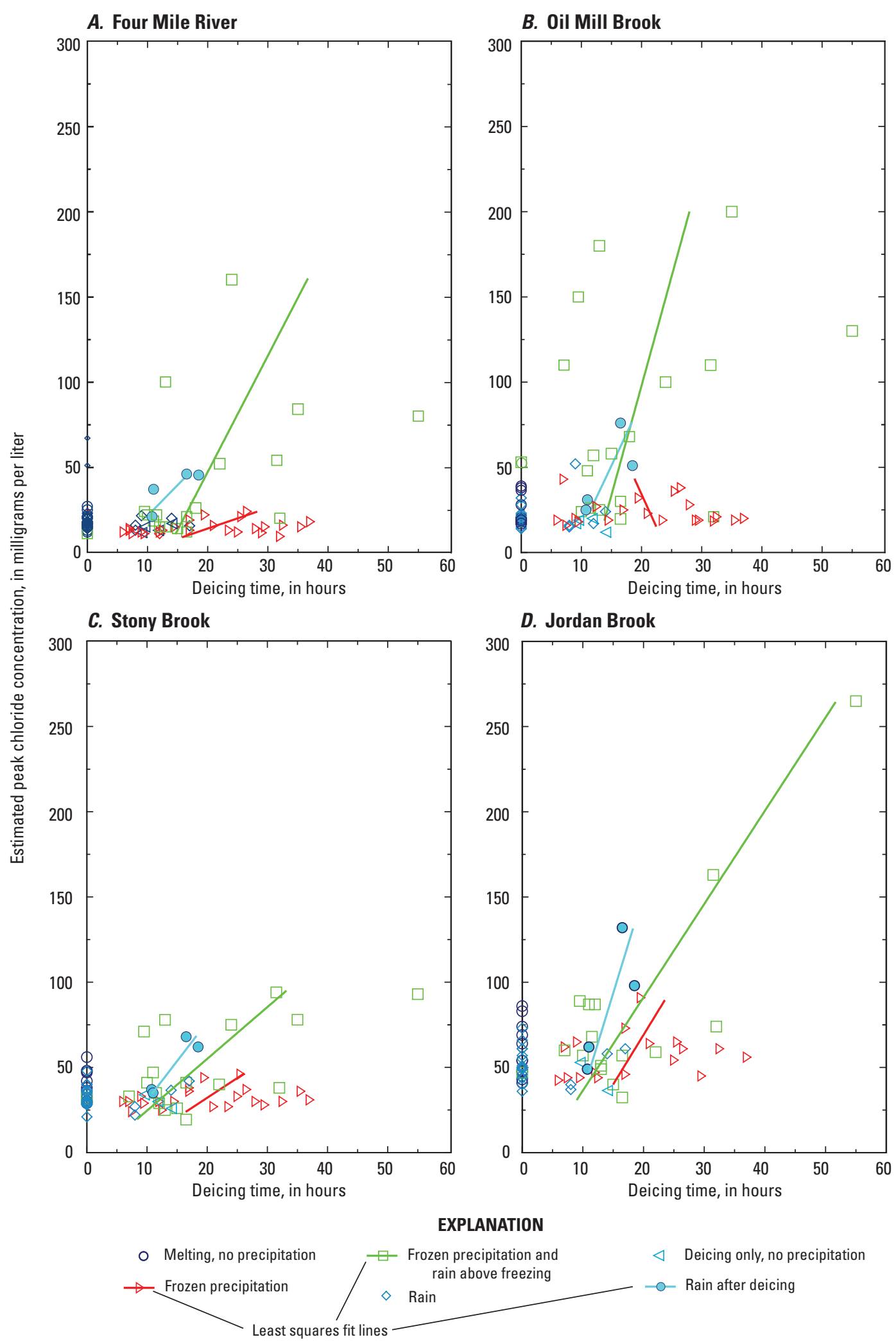

Figure 19. Deicing time as a function of estimated peak continuous chloride concentrations at the $A$, Four Mile River, $B$, Oil Mill Brook, $C$, Stony Brook, and D, Jordan Brook downstream sites, southeastern Connecticut, from November 2008 to September 2011. 


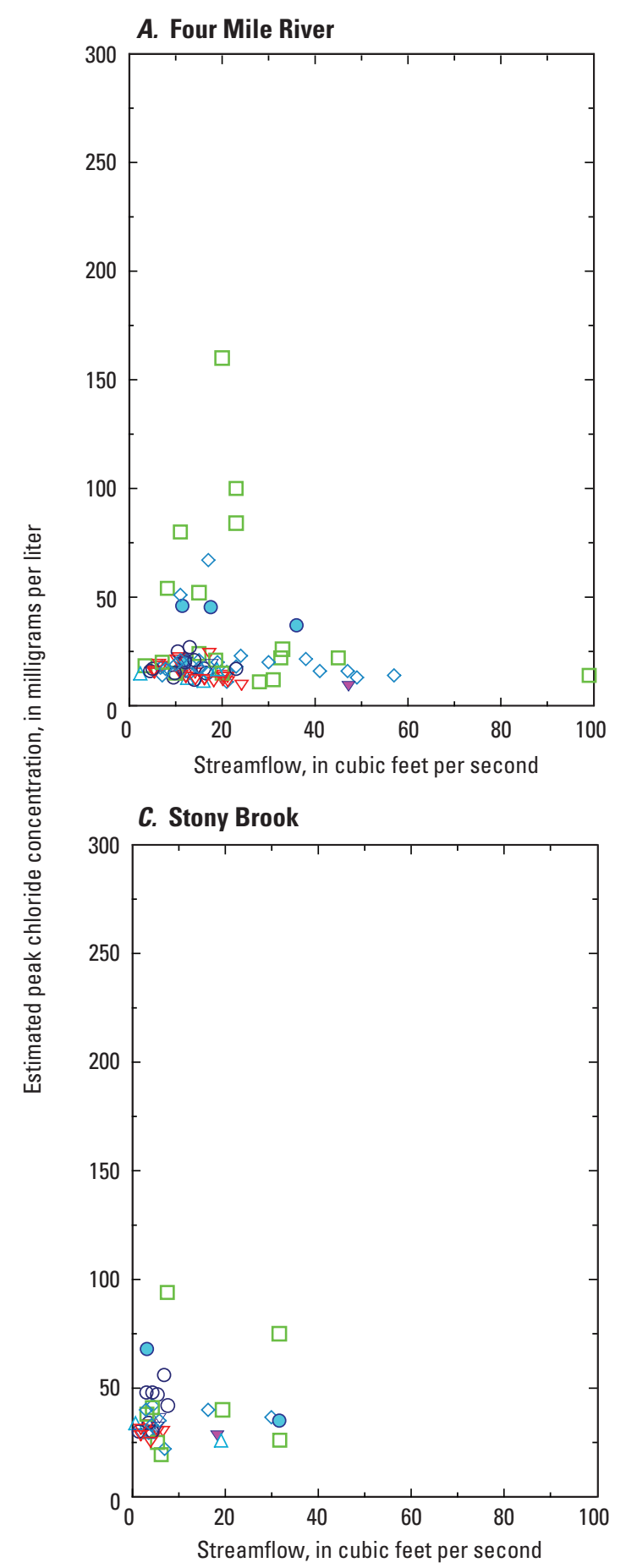

\section{B. Oil Mill Brook}

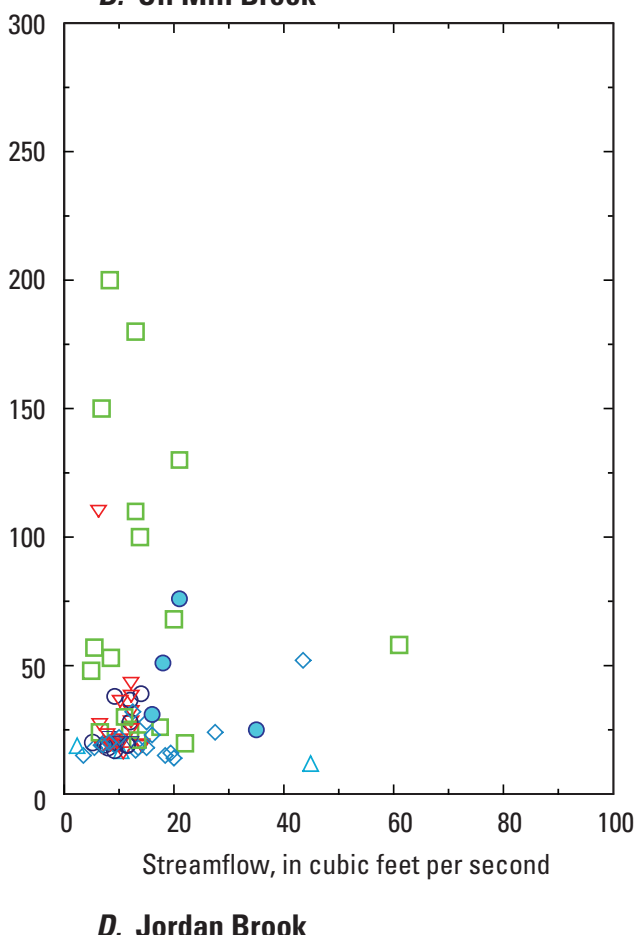

D. Jordan Brook

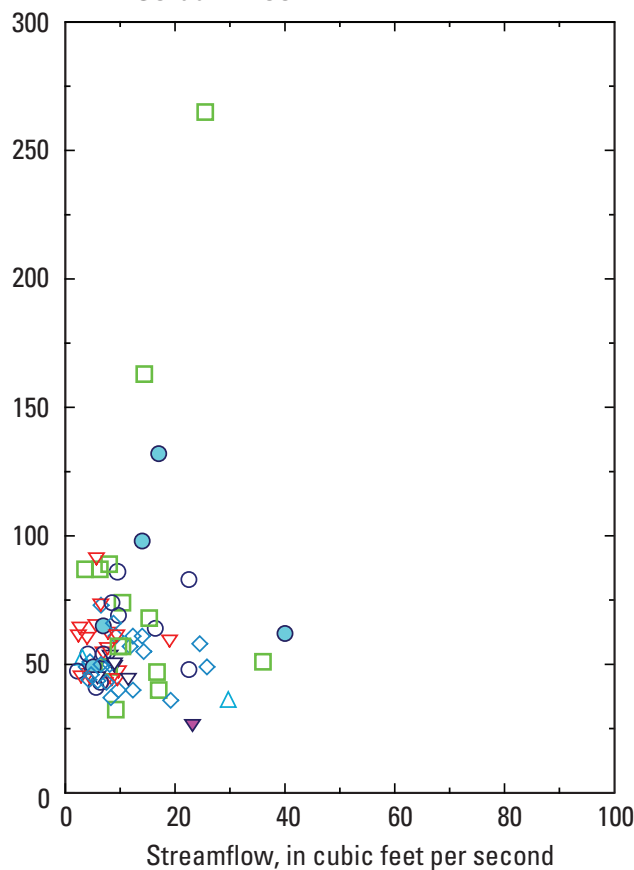

\section{EXPLANATION}

○elting, no precipitation

$\nabla \quad$ Frozen precipitation $\square \quad$ Frozen precipitation and rain

$\diamond$ Rain $\begin{array}{ll}\triangle & \text { Deicing only, no precipitation } \\ \bigcirc & \text { Rain after deicing } \\ \nabla & \text { No precipitation }\end{array}$

Figure 20. Streamflow as a function of estimated peak continuous chloride concentrations at the $A$, Four Mile River, $B$, Oil Mill Brook, $C$, Stony Brook, and $D$, Jordan Brook downstream sites, southeastern Connecticut, from November 2008 to September 2011. 


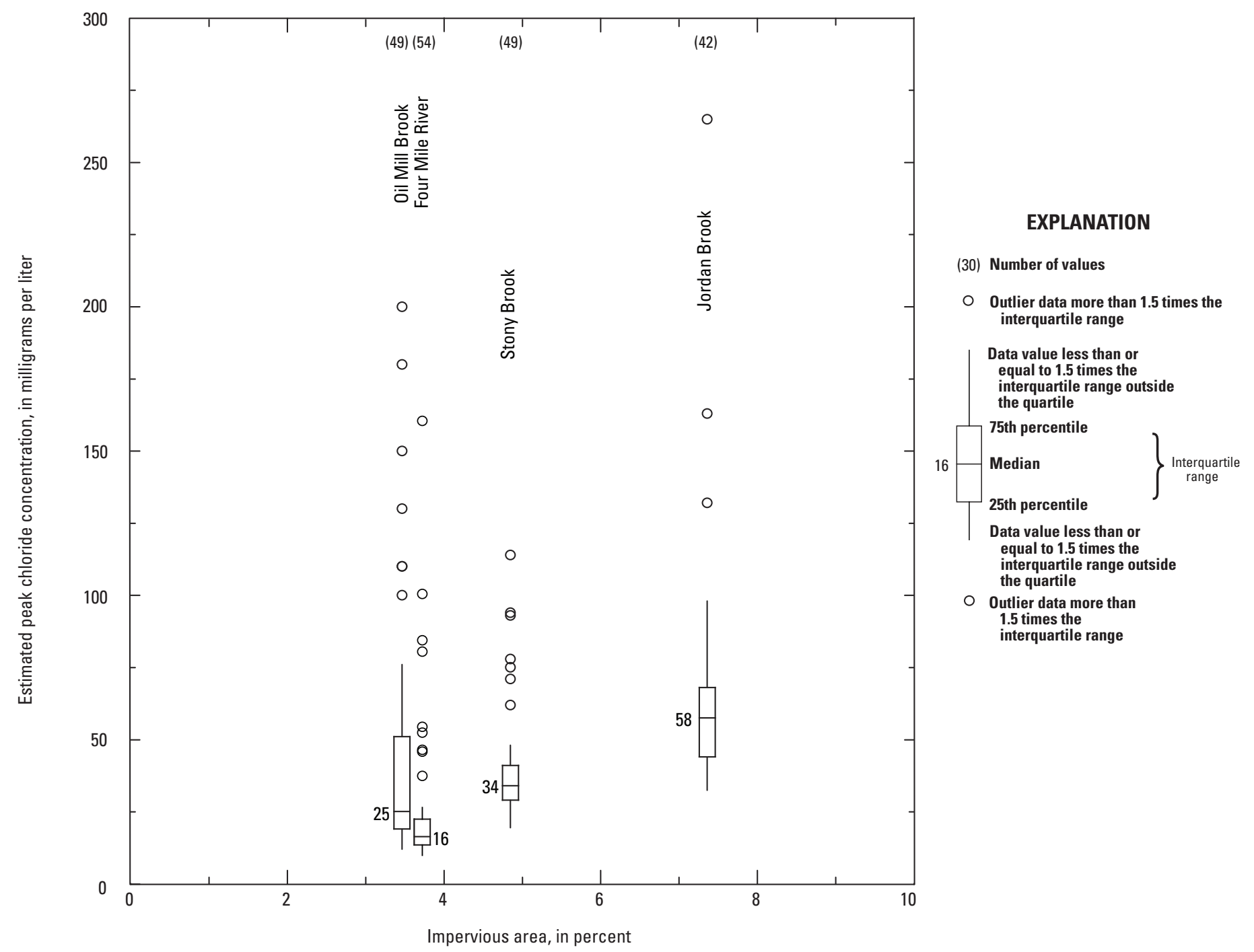

Figure 21. Distributions of the estimated peak chloride concentrations as a function of the percentage of impervious area at the Four Mile River, Oil Mill Brook, Stony Brook, and Jordan Brook downstream sites, southeastern Connecticut, from November 2008 to September 2011. 
All of the explanatory variables were significant and, with the exception of specific conductance of base flow, had positive values indicating a positive correlation with peak specific conductance and estimated peak $\mathrm{Cl}^{-}$concentrations after deicing events. Winter precipitation with rain, which includes storms with precipitation consisting of rain mixed with frozen precipitation or rain after deicing, had the highest peak specific conductance, as discussed in the previous section. The model was not very sensitive to the duration of deicer application or the amount of $\mathrm{Cl}^{-}$in deicer applied, but the amount of $\mathrm{Cl}^{-}$applied to State roads per lane mile and the highway lane miles divided by watershed area were used as explanatory variables. The presence of snow on the ground before the deicing event is another explanatory variable that generally resulted in higher peak specific conductance and improved the model. The specific conductance of base flow also was found to improve the model. Specific conductance typically increased after deicing events but was actually lower during many of the smaller winter storm peaks than specific conductance observed during base-flow conditions. Mullaney (2009) observed that basins with high concentrations of $\mathrm{Cl}^{-}$in groundwater were more likely to exceed the recommended chronic criteria.

\section{Chloride Concentrations and Aquatic Toxicity Criteria}

No exceedances of the chronic and acute $\mathrm{Cl}^{-}$toxicity criteria for aquatic life were observed in the four watersheds, largely because of the predominance of forested land use in the area. The highest estimated peak $\mathrm{Cl}^{-}$concentration of $270 \mathrm{mg} / \mathrm{L}$ at Jordan Brook was well below the acute toxicity criteria of $860 \mathrm{mg} / \mathrm{L}$. A deicing study of more urbanized watersheds found that exceedances are more likely to occur in streams with an annual average $\mathrm{Cl}^{-}$concentration of about
$102 \mathrm{mg} / \mathrm{L}$ (Trowbridge and others, 2010). Mean $\mathrm{Cl}^{-}$concentrations from continuous data for the four downstream sites ranged from $14 \mathrm{mg} / \mathrm{L}$ at Four Mile River to $42 \mathrm{mg} / \mathrm{L}$ at Jordan Brook (table 9A), well below the threshold value of $102 \mathrm{mg} / \mathrm{L}$ observed by Trowbridge and others (2010).

\section{Chloride Load With the Addition of Two I-95 Lanes}

The relation between peak $\mathrm{Cl}^{-}$concentrations and the amount of $\mathrm{Cl}^{-}$in deicer applied to State-maintained roads yielded a least squares regression line that was used to estimate the increase in peak $\mathrm{Cl}^{-}$concentrations, given an estimated increase in deicer $\mathrm{Cl}^{-}$required to treat the added lanes (table 5). The addition of a lane to both northbound and southbound directions on I-95 between the Connecticut and Thames Rivers would result in an estimated increase of about 2 to 11 percent in $\mathrm{Cl}^{-}$load from deicers applied to I-95 and other roads maintained by ConnDOT (tables 5 and 10). The largest estimated increase in $\mathrm{Cl}^{-}$load is for Four Mile River and Stony Brook (11 and 11.2 percent, respectively), the watersheds with the greatest miles of I-95 corridor relative to the total lane miles maintained by ConnDOT. Oil Mill Brook and Jordan Brook had relatively small increases in estimated $\mathrm{Cl}^{-}$load (2.2 and 5.5 percent, respectively) from the addition of a lane to I-95. The addition of a highway lane could cause increases in $\mathrm{Cl}^{-}$concentrations in streams but not likely above aquatic habitat criteria under existing land-use conditions. Furthermore, best management practices are available for minimizing environmental effects related to highway construction, including retention ponds, vegetative buffer strips, and catch basins (Ellebracht and Clark, 2013; Environmental Protection Agency, 2004), and may result in little or no increase in $\mathrm{Cl}^{-}$concentrations.

Table 13. Multiple linear regression estimates of model coefficients and standard errors, $t$-statistics, and $p$-values for the dependent variable natural log of peak specific conductance during winter storms for the Four Mile River, Oil Mill Brook, Stony Brook, and Jordan Brook watersheds, southeastern Connecticut, from November 2008 to September 2011.

$[\mu \mathrm{S} / \mathrm{cm}$; microsiemens per centimeter at 25 degrees Celsius; <, less than]

\begin{tabular}{lccrr}
\hline \multicolumn{1}{c}{ Variable } & $\begin{array}{c}\text { Parameter } \\
\text { estimate }\end{array}$ & $\begin{array}{c}\text { Standard } \\
\text { error }\end{array}$ & $\boldsymbol{t}$-statistic & $\boldsymbol{p}$-value \\
\hline Intercept & 3.8730 & 0.1465 & 26.4401 & $<0.0001$ \\
Snow on ground before deicing event (yes or no) & 0.2050 & 0.0539 & 3.8066 & 0.0002 \\
Precipitation type (includes rain or not) & 0.4023 & 0.0498 & 8.0822 & $<0.0001$ \\
Specific conductance in base flow, mS/cm & -0.0055 & 0.0007 & -7.5597 & $<0.0001$ \\
Highway lane miles divided by watershed area, miles per square mile & 0.0966 & 0.0091 & 10.6091 & $<0.0001$ \\
Deicer chloride, tons per lane mile & 0.8259 & 0.1617 & 5.1073 & $<0.0001$ \\
\hline
\end{tabular}




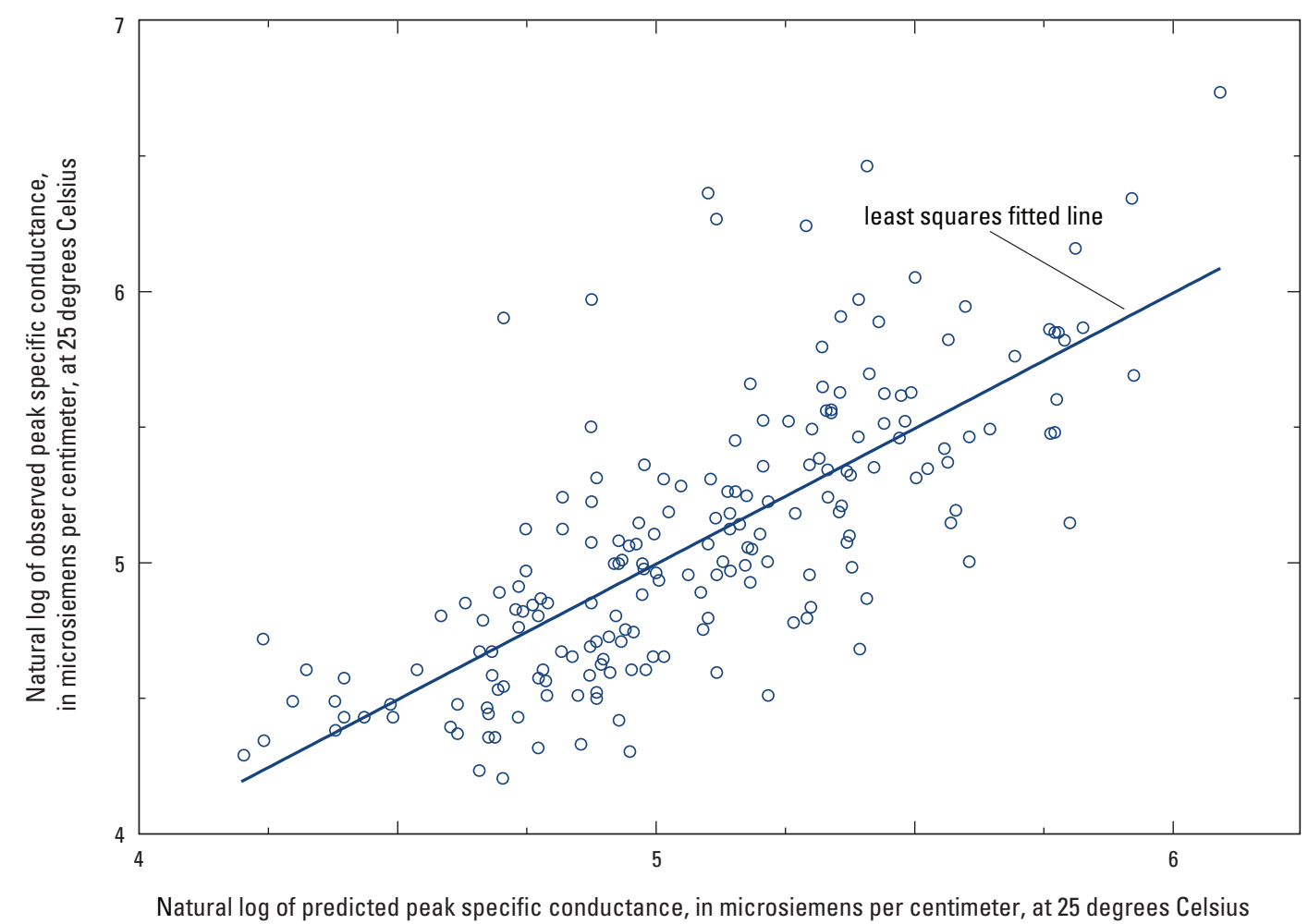

Figure 22. Natural log of predicted peak specific conductance from multiple linear regression modeling, and natural log of observed peak specific conductance for winter storms at Four Mile River, Oil Mill Brook, Stony Brook, and Jordan Brook downstream sites, southeastern Connecticut, from November 2008 to September 2011. 


\section{Summary and Conclusions}

The U.S. Geological Survey, the Federal Highway Administration, and the Connecticut Department of Transportation conducted a cooperative study to evaluate the potential effects of deicer application on the quality of streamwater in four watersheds crossed by Interstate 95 (I-95) in southeastern Connecticut.

Streamflow and water quality were studied at the four watersheds-Four Mile River, Oil Mill Brook, Stony Brook, and Jordan Brook. Streamgages were instrumented and maintained at sites downstream from the highway, and continuous water-quality monitors were installed and maintained at upstream and downstream sites. Water quality was assessed by analyzing the dissolved ions in grab samples and by continuous recording of data on water temperature and specific conductance. Grab samples were collected (1) during winter stormwater-runoff events, such as winter storms or subsequent periods of rain or warm temperatures in which melting occurred, and (2) approximately monthly during routine conditions and analyzed for chloride $\left(\mathrm{Cl}^{-}\right)$concentrations and specific conductance, and (3) during base-flow and moderate-flow conditions and analyzed for major ions and concentrations of dissolved iron, manganese, and bromide $(\mathrm{Br})$.

Estimated $\mathrm{Cl}^{-}$concentrations at the eight water-quality monitoring sites were well below the U.S. Environmental Protection Agency recommended chronic and acute chloride toxicity criteria for aquatic life. Specific conductance and estimated $\mathrm{Cl}^{-}$concentrations in streams, particularly at sites downstream from I-95, increased during discharge events in the winter and early spring as a result of deicers applied to roads and washed off by stormwater or meltwater. During winter storms, deicing activities, or subsequent periods of melting, specific conductance peaked as high as 859 microsiemens per centimeter (270 milligrams per liter estimated $\mathrm{Cl}^{-}$concentration) at Jordan Brook.

Estimated $\mathrm{Cl}^{-}$concentration peaks varied with the type of winter storm or precipitation event and were highest during or after winter storms of frozen precipitation and rain, in which the rain effectively washed off the deicers that were applied to melt the snow or ice. Estimated $\mathrm{Cl}^{-}$concentration peaks also were high during or after rain that occurred after deicing. $\mathrm{Cl}^{-}$ concentration peaks correlated positively with the duration of deicer application but generally not with streamflow. $\mathrm{Cl}^{-}$concentration peaks during the winter season were highest during low streamflow peaks, with the exception of Stony Brook. The $\mathrm{Cl}^{-}$concentration peaks at Jordan Brook were highest during events in which there was pre-existing snow, and streamwater was apparently affected by the release of salt leachate in snow piles associated with upstream parking lots in the urbanized areas.

Air temperature also had an important effect on the melting and release of deicing salts from highways, roads, and parking lots. $\mathrm{Cl}^{-}$concentration peaks generally were highest when the minimum air temperature was between -8 and 3 degrees Celsius, temperatures at which melting is possible when deicers are applied. Several high $\mathrm{Cl}^{-}$concentration peaks were preceded by an extended period of below-freezing air temperatures; such conditions can result in a delayed release of salt to the stream. Most of these occurrences involved "Frozen precipitation and rain" events.

Groundwater concentrations of $\mathrm{Cl}^{-}$were highest downstream from I-95 at the Four Mile River site. Although there appears to be little interaction with streamwater, there is concern for the possible exceedance of the aquatic criteria farther downstream. A plot of $\mathrm{Cl}^{-}$concentration in relation to $\mathrm{Cl}^{-} /$ $\mathrm{Br}$ mass concentration ratios, and the proximity of a former landfill and sewage lagoon upstream, indicate that a likely source of $\mathrm{Cl}^{-}$is landfill leachate.

$\mathrm{Cl}^{-}$loads in streams generally were highest in the winter and early spring. The estimated daily mean yield for the four monitoring sites downstream from I-95 ranged from 0.056 ton per day per square mile for the least developed watershed, Oil Mill Brook, to 0.27 ton per day per square mile for the watershed with the highest percentage of urban development and impervious area, Jordan Brook. The $\mathrm{Cl}^{-}$load from atmospheric deposition was estimated from the $\mathrm{Cl}^{-}$concentrations measured at National Atmospheric Deposition Program station in Abington, Connecticut. The estimated contribution of $\mathrm{Cl}^{-}$from atmospheric deposition ranged from 0.07 percent of $\mathrm{Cl}^{-}$load at the Jordan Brook watershed to 0.57 percent at the Oil Mill Brook watershed. A comparison of the estimated $\mathrm{Cl}^{-}$load inputs and outputs generally showed that $\mathrm{Cl}^{-}$load inputs were slightly larger than the $\mathrm{Cl}^{-}$load leaving the watershed at most of the sites during most years. The lag time between introduction of $\mathrm{Cl}^{-}$to the watershed and transport to the stream, as well as uncertainty in the load estimates, may be the cause of this small discrepancy. Estimates of direct infiltration of $\mathrm{Cl}^{-}$to groundwater that originates from septic-tank drainfields, fertilizers, or other anthropogenic sources were not within the scope of this project. The estimation of groundwater flow exiting the watersheds in the subsurface was also beyond the scope of the project.

The addition of a lane mile in both directions on I-95 is estimated to increase the $\mathrm{Cl}^{-}$load from deicers applied to I-95 and other roads maintained by ConnDOT by about 2 to 11 percent. This projected $\mathrm{Cl}^{-}$load increase was determined by using the same application rates of deicers presently used on State roads for the addition of a single lane in each direction of I-95 between the Connecticut and Thames Rivers. The largest estimated increases in $\mathrm{Cl}^{-}$load were at Four Mile River and Stony Brook (11 and 11.2 percent, respectively), the watersheds with the greatest number of miles of I-95 corridor relative to the total lane miles maintained by ConnDOT. Oil Mill Brook and Jordan Brook had relatively small increases in estimated $\mathrm{Cl}^{-}$load (2.2 and 5.5 percent, respectively) from the addition of two lanes to I-95.

A multiple linear regression model was developed to describe the variability of the log of peak $\mathrm{Cl}^{-}$concentrations. Five significant variables best explained the variability in the natural log of the peak $\mathrm{Cl}^{-}$concentration after deicing events: (1) snow on ground before deicing event, (2) winter 
precipitation with rain, (3) specific conductance in base flow, (4) highway lane miles divided by watershed area, and (5) the amount of $\mathrm{Cl}^{-}$from deicers applied to State roads per lane mile. This study provides a useful conceptual framework for understanding $\mathrm{Cl}^{-}$concentration increases in streamflow associated with deicer application in the northeastern United States.

\section{References Cited}

Brown, C.J., Mullaney, J.R., Morrison, Jonathan, and Mondazzi, Remo, 2011, Preliminary assessment of chloride concentrations, loads, and yields in selected watersheds along the Interstate 95 corridor, southeastern Connecticut, 2008-09: U.S. Geological Survey Open-File Report 2011-1018, 41 p. [Also available at http://pubs.usgs.gov/of/2011/1018/.]

Brown, C.J., Starn, J.J., Stollenwerk, K.G., Mondazzi, R.A., and Trombley, T.J., 2009, Aquifer chemistry and transport processes in the zone of contribution to a public-supply well in Woodbury, Connecticut, 2002-06: U.S. Geological Survey Scientific Investigations Report 2009-5051, 158 p. [Also available at http://pubs.usgs.gov/sir/2009/5051/.]

Bubeck, R.C., Diment, W.H., Deck, B.L., Baldwin, A.L., and Lipton, S.D., 1971, Runoff of deicing salt-Effect on Irondequoit Bay, Rochester, New York: Science, v. 172, p. 1128-1132.

Cassanelli, J.P., and Robbins, G.A, 2013, Effects of road salt on Connecticut's groundwater-A statewide centennial perspective: Journal of Environmental Quality, v. 42, no. 3, p. 737-748.

Chabaeva, A.A., Civco, D.L., and Prisloe, Sandy, 2004, Development of a population and land use based regression model to calculate the amount of imperviousness, in Proceedings, 2004 American Society for Photogrammetry and Remote Sensing conference, Denver, Colorado, 24-28 May: American Society for Photogrammetry and Remote Sensing, 9 p., accessed September 10, 2009, at http://nemo.uconn.edu/ tools/impervious_surfaces/pdfs/Chabaeva_etal_2004.pdf.

Church, P.E., and Friesz, P.J., 1993, Effectiveness of highwaydrainage systems in preventing road-salt contamination of groundwater-Preliminary findings: Transportation Research Board, Transportation Research Record 1420, p. 56-64.

Colombo, M.J., and Trench, E.C.T., 2002, Trends in surfacewater quality in Connecticut: U.S. Geological Survey Water-Resources Investigations Report 02-4012, 39 p.

Connecticut Department of Environmental Protection, 1995, Leachate and wastewater discharge inventory: Hartford, Conn., Connecticut Department of Environmental Protection, Environmental and Geographic Information Center Digital Shapefile, scale 1:50,000, accessed September 10, 2009, at http://www.ct.gov/dep/cwp/view. asp?A=2698\&Q=322898.
Connecticut Department of Environmental Protection, 2009, State of Connecticut water quality standards, effective February 25, 2011: Connecticut Department of Energy and Environmental Protection Web site, accessed March 1, 2013, at http://www.ct.gov/dep/lib/dep/water/water_quality_standards/water_quality_standards_proposed_12_22_09.pdf.

Connecticut Department of Transportation, 2009, Interim snow \& ice guidelines-2008-09: Connecticut Department of Transportation, Bureau of Engineering \& Highway Operations, $53 \mathrm{p}$.

Connecticut Department of Transportation, 2013, Department of Transportation Snow and Ice Program: Connecticut Department of Transportation, Bureau of Engineering \& Highway Operations, 50 p.

Conover, W.J., and Iman, R.L., 1981, Rank transformations as a bridge between parametric and nonparametric statistics: American Statistician, v. 35, p. 124-129.

Corsi, S.R., Graczyk, D.J., Geis, S.W., Booth, N.L., and Richards, K.D., 2010, A fresh look at road salt-Aquatic toxicity and water-quality impacts on local, regional, and national scales: Environmental Science \& Technology, v. 44, no. 19, p. 7376-7382.

Davis, S.N., Whittemore, D.O., and Fabryka-Martin, J., 1998, Uses of chloride/bromide ratios in studies of potable water: Ground Water, v. 36, p. 338-350.

Ellebracht, B.J., and Clark, S.E., 2013, Relating stormwater treatment device design criteria to effluent quality-An indepth statistical analysis of the BMP database, in Patterson, C.L., Struck, S.D., and Murray, D.J., Jr., eds., World Environmental and Water Resources Congress 2013-Showcasing the future: Reston, Va., American Society of Civil Engineers, p. 325-329.

Fishman, M.J., and Friedman, L.C., 1989, Methods for determination of inorganic substances in water and fluvial sediments: U.S. Geological Survey Techniques of WaterResources Investigations, book 5, chap. A1, 545 p. [Also available at http://pubs.usgs.gov/twri/twri5-a1/.]

Gay, F.B., and Melching, C.S., 1995, Relation of precipitation quality to storm type, and constituent loads in Massachusetts, 1983-85: U.S. Geological Survey Water-Resources Investigations Report 94-4224, 82 p.

Grady, S.J., 1993, Effects of land use on quality of water in stratified-drift aquifers in Connecticut: U.S. Geological Survey Open-File Report 91-200, 87 p.

Grady, S.J., and Mullaney, J.R., 1998, Natural and human factors affecting shallow water quality in surficial aquifers in the Connecticut, Housatonic, and Thames River Basins: U.S. Geological Survey Water-Resources Investigations Report 98-4042, 81 p. 
Granato, G.E., 1996, Deicing chemicals as a source of constituents in highway runoff: National Research Council, Transportation Research Board, Transportation Research Record 1533, p. 50-58.

Granato, G.E., 2013, Stochastic Empirical Loading and Dilution Model (SELDM) version 1.0.0: U.S. Geological Survey Techniques and Methods, book 4, chap. C3, 112 p., 1 CD-ROM, http://pubs.usgs.gov/tm/04/c03.

Granato, G.E., Church, P.E., and Stone, V.J., 1995, Mobilization of major and trace constituents of highway runoff in groundwater potentially caused by deicing-chemical migration: National Research Council, Transportation Research Board, Transportation Research Record 1483, p. 92-104.

Granato, G.E., and Smith, K.P., 1999, Estimating concentrations of road-salt constituents in highway runoff from measurements of specific conductance: U.S. Geological Survey Water-Resources Investigations Report 99-4077, 22 p. [Also available at http://ma.water.usgs.gov/ggranato/ WRIR99-4077.pdf.]

Gurnell, A.M., Brown, G.H., and Tranter, M., 1994, Sampling strategy to describe the temporal hydrochemical characteristics of an alpine proglacial stream: Hydrological Processes, v. 8 , p. 1-25.

Harte, P.T., and Trowbridge, P.R., 2010, Mapping of roadsalt-contaminated groundwater discharge and estimation of chloride load to a small stream in southern New Hampshire, USA: Hydrological Processes, v. 24, p. 2349-2368.

Heath, Douglas, and Beleval, Marcel, 2013, Road salt transport at two municipal wellfields in Wilmington, Massachusetts: Journal of American Water Works Association, v. 25, no. 24 , p. 315-337.

Helsel, D.R., and Hirsch, R.M., 1995, Statistical methods in water resources: Amsterdam, The Netherlands, Elsevier Science Publishing, 529 p.

Howard, K.W.F., and Haynes, Janet, 1993, Groundwater contamination due to road de-icing chemicals - Salt balance implications: Geoscience Canada, v. 20, p. 1-8.

Iman, R.L., and Conover, W.J., 1983, A modern approach to statistics: New York, John Wiley, 497 p.

Jagucki, M.L., and Darner, R.A., 2001, Groundwater quality in Geauga County, Ohio-Review of previous studies, status in 1999, and comparison of 1986 and 1999 data: U.S. Geological Survey Water-Resources Investigations Report 01-4160, 60 p.

Katz, B.G., Eberts, S.M., and Kauffman, L.J., 2011, Using $\mathrm{Cl} / \mathrm{Br}$ ratios and other indicators to assess potential impacts on groundwater quality from septic systems - A review and examples from principal aquifers in the United States: Journal of Hydrology, v. 397, p. 151-166.
Kaushal, S.S., Groffman, P.M., Likens, G.E., Belt, K.T., Stack, W.P., Kelly, V.R., Band, L.E., and Fisher, G.T., 2005, Increased salinization of fresh water in the northeastern United States: Proceedings of the National Academy of Sciences, v. 102, p. 13517-13520.

Kelly, W.R., Panno, S.V., Hackley, K.C., Hwang, Hue-Hwa, Marinsek, A.T., and Markus, Momcilo, 2010, Using chloride and other ions to trace sewage and road salt in the Illinois Waterway: Applied Geochemistry, v. 25, p. 661-673.

Kostick, D.S., 1993, The material flow of salt: U.S. Department of the Interior, Bureau of Mines, Information Circular 9343, 32 p.

Kostick, D.S., Milanovich, J.A., and Coleman, R.R., 2007, Salt, in 2005 Minerals Yearbook: U.S. Geological Survey Minerals Yearbook, v. 1, p. 63.1-63.20, accessed November 1, 2009, at http://minerals.er.usgs.gov/minerals/ pubs/commodity/salt/salt_myb05.pdf.

Langbein, W.B., and others, 1947, Topographic characteristics of drainage basins: U.S. Geological Survey Water-Supply Paper 968-C, p. 125-158.

Massachusetts Department of Transportation, 2012, MassDOT Snow \& Ice Control Program-2012 Environmental Status and Planning Report EOEA\#11202-Public Review Draft, February 2012: Massachusetts Department of Transportation, Highway Division, 125 p.

Melvin, R.L., and Bingham, J.W., 1991, Availability of water from stratified-drift aquifers in the Farmington River valley, Simsbury, Connecticut: U.S. Geological Survey WaterResources Investigations Report 89-4140, 77 p.

Miller, D.R., Warner, G.S., Ogden, F.L., and DeGaetano, A.T., 2002, Precipitation in Connecticut: Connecticut Institute of Water Resources Special Reports, 65 p.

Mirecki, J.E., and Parks, W.S., 1994, Leachate geochemistry at a municipal landfill, Memphis, Tennessee: Ground Water, v. 32, no. 3, p. 390-398.

Mullaney, J.R., Lorenz, D.L., and Arntson, A.D., 2009, Chloride in groundwater and surface water in areas underlain by the glacial aquifer system, northern United States: U.S. Geological Survey Scientific Investigations Report 2009-5086, 41 p.

National Atmospheric Deposition Program (NADP), 2012, Monitoring our changing chemical climate: Champaign, Ill., NADP Program Office, Illinois State Water Survey, accessed May 13, 2013, at http://nadp.sws.uiuc.edu.

National Oceanic and Atmospheric Administration, National Climatic Data Center, [n.d.], Nearest observations to Groton, CT: National Oceanic and Atmospheric Administration, National Climatic Data Center Web site, accessed June 4, 2013, at http://www.nohrsc.noaa.gov/technology/. 
National Operational Hydrologic Remote Sensing Center, 2005, Overview of the center's Web site and products: Minneapolis, Minn., National Weather Service, 15 p., accessed May 13, 2013, at http://www.nohrsc.noaa.gov/technology/pdf/ NOHRSC_web_overview.pdf.

Ostendorf, D.W., Hinlein, E.S., Rotaru, Camelia, and DeGroot, D.J., 2006, Contamination of groundwater by outdoor highway deicing agent storage: Journal of Hydrology, v. 326, p. $109-121$.

Panno, S.V., Hackley, K.C., Hwang, H.H., Greenberg, S.E., Krapac, I.G., Landsberger, S., and O'Kelly, D.J., 2006, Characterization and identification of $\mathrm{Na}-\mathrm{Cl}$ sources in ground water: Ground Water, v. 44, no. 2, p. 176-187.

Prisloe, M.S., Wilson, E.H., and Arnold, Chester, 2003, Final report-Refinement of population-calibrated land-cover-specific impervious surface coefficients for Connecticut: Nemo FY02 Workplan, DEP project 01-08: University of Connecticut, Middlesex County Extension Center, 20 p.

Prych, E.A., 1998, Using chloride and chlorine-36 as soil-water tracers to estimate deep percolation at selected locations on the U.S. Department of Energy Hanford site, Washington: U.S. Geological Survey Water-Supply Paper 2481, 67 p.

Ramakrishna, D.M., and Viraraghavan, Thiruvenkatachari, 2005, Environmental impact of chemical deicers - A review: Water, Air, and Soil Pollution, v. 166, p. 49-63.

Rantz, S.E., and others, 1982, Measurement and computation of streamflow_-Volume 1. Measurement of stage and discharge: U.S. Geological Survey Water-Supply Paper 2175, 284 p.

Runkel, R.L., Crawford, C.G., and Cohn, T.A., 2004, Load estimator (LOADEST) - A FORTRAN program for estimating constituent loads in streams and rivers: U.S. Geological Survey Techniques and Methods, book 4, chap. A5, 69 p.

Sears Ecological Applications Co, LLC, 2009, Material safety data sheet: Sears Ecological Applications Co, LLC, accessed January 20, 2010, at http://www.seaco.com/images/ MSDS\%20IBG\%20II\%2020.pdf.

Smith, R.A., Alexander, R.B., and Wolman, M.G., 1987, Water-quality trends in the Nation's Rivers: Science, v. 235, p. $1607-1615$.

Sokal, R.R., and Rohlf, F.J., 1969, Biometry: San Francisco, W.H. Freeman, $776 \mathrm{p}$.

Stiff, H.A., Jr., 1951, The interpretation of chemical water analysis by means of patterns: Journal of Petroleum Technology, v. 3. no. 10 , p. 15-17.

Stoline, M.R., 1981, The status of multiple comparisonsSimultaneous inference of all pairwise comparisons in oneway ANOVA designs: American Statistician, v. 35, p. 134-141.
Stone, J.R., Schafer, J.P., London, E.H., and Thompson, W.B., 1992, Surficial materials map of Connecticut: U.S. Geological Survey Special Map, 2 sheets, scale 1:125,000.

Thomas, M.A., 2000, The effect of residential development on ground-water quality near Detroit, Michigan: Journal of the American Water Resources Association, v. 36, no. 5, p. 1023-1038.

Toler, L.G., and Pollock, S.J., 1974, Retention of chloride in the unsaturated zone: U.S. Geological Survey Journal of Research, v. 2, no. 1, p. 119-123.

Trench, E.C.T., 1996, Trends in surface-water quality in Connecticut, 1969-88: U.S. Geological Survey Water-Resources Investigations Report 96-4161, 176 p.

Trowbridge, P.R., Kahl, J.S., Sassan, D.A., Heath, D.L., and Walsh, E.M., 2010, Relating road salt to exceedances of the water quality standard for chloride in New Hampshire streams: Environmental Science \& Technology, v. 44, no. 13 , p. 4903-4909.

U.S. Environmental Protection Agency, 1988, Ambient water quality criteria for chloride_-1988: Duluth, Minn., Office of Research and Development, Environmental Research Laboratory, EPA 440588001.

U.S. Environmental Protection Agency, 1994, Nonpoint sources pollution control program: U.S. Environmental Protection Agency Report EPA-841-F-94-005.

U.S. Environmental Protection Agency, 2001, 2001 National Land Cover Data: Multi-Resolution Land Characteristics Consortium, accessed February 1, 2010, at http://www.epa. gov/mrlc/nlcd-2001.html.

U.S. Environmental Protection Agency, 2011, 2011 edition of the drinking water standards and health advisories: U.S. Environmental Protection Agency EPA 820-R-11-002, 12 p., accessed June 13, 2006, at http:/www.epa.gov/safewater/ consumer/2ndstandards.html.

U.S. Geological Survey, 2015, Salt-Statistics and Information: U.S. Geological Survey Mineral Commodities Summaries, http://minerals.usgs.gov/minerals/pubs/commodity/ salt/index.html.

University of Connecticut, 2010, Land cover category descriptions: College of Agriculture \& Natural Resources Center for Land Use Education And Research (CLEAR), accessed May 2, 2013, at http://clear.uconn.edu/projects/landscape/ category_description.htm.

Vengosh, Avner, and Pankratov, Irena, 1998, Chloride/bromide and chloride/fluoride ratios of domestic sewage effluents and associated contaminated ground water: Ground Water, v. 36 , no. 5, p. 815-824. 
Vogelmann, J.E., Sohl, T.L., Campbell, P.V., and Shaw, D.M., 1998, Regional land cover characterization using LANDSAT thematic mapper data and ancillary data sources: Environmental Monitoring and Assessment, v. 51, p. 415-428.

Wagner, R.J., Boulger, R.W., Jr., Oblinger, C.J., and Smith, B.A., 2006, Guidelines and standard procedures for continuous water-quality monitors - Station operation, record computation, and data reporting: U.S. Geological Survey Techniques and Methods, book 1, chap. D3, 51 p. plus 8 attachments, accessed April 10, 2006, at http://pubs.water.usgs.gov/tm1d3.

Wilde, F.D., ed., 2004, Cleaning of equipment for water sampling (ver. 2.0): U.S. Geological Survey Techniques of Water-Resources Investigations, book 9, chap. A3, accessed March 17, 2009, at http://pubs.water.usgs.gov/twri9A3/.
Wilde, F.D., 2005, Preparations for water sampling: U.S. Geological Survey Techniques of Water-Resources Investigations, book 9, chap. A1, accessed March 17, 2009, at http://pubs.water.usgs.gov/twri9A1/.

Williams, D.D., Williams, N.E., and Cao, Yong, 1999, Road salt contamination of groundwater in a major metropolitan area and development of a biological index to monitor its impact: Water Research, v. 34, no. 1, p. 127-138.

Wulkowicz, G.M., and Saleem, Z.A., 1974, Chloride balance of an urban basin in the Chicago area: Water Resources Research, v. 10, no. 5, p. 974-982. 

Appendixes 


\section{Appendix 1. Specific Conductance and Chloride Concentrations at Four Mile River, Oil Mill Brook, Stony Brook, and Jordan Brook, Southeastern Connecticut, from November 2008 to September 2011}

Table 1-1. Physical characteristics and chemical constituents in streamwater and groundwater samples from upstream and downstream monitoring sites at Four Mile River, Oil Mill Brook, Stony Brook, and Jordan Brook, southeastern Connecticut, from November 2008 to September 2011.

[Available for download separately from http://dx.doi.org/10.3133/sir20155057] 


\section{Appendix 2. Specific Conductance Measurements and Streamflow at Four Mile River, Southeastern Connecticut, from November 2008 to September 2011}
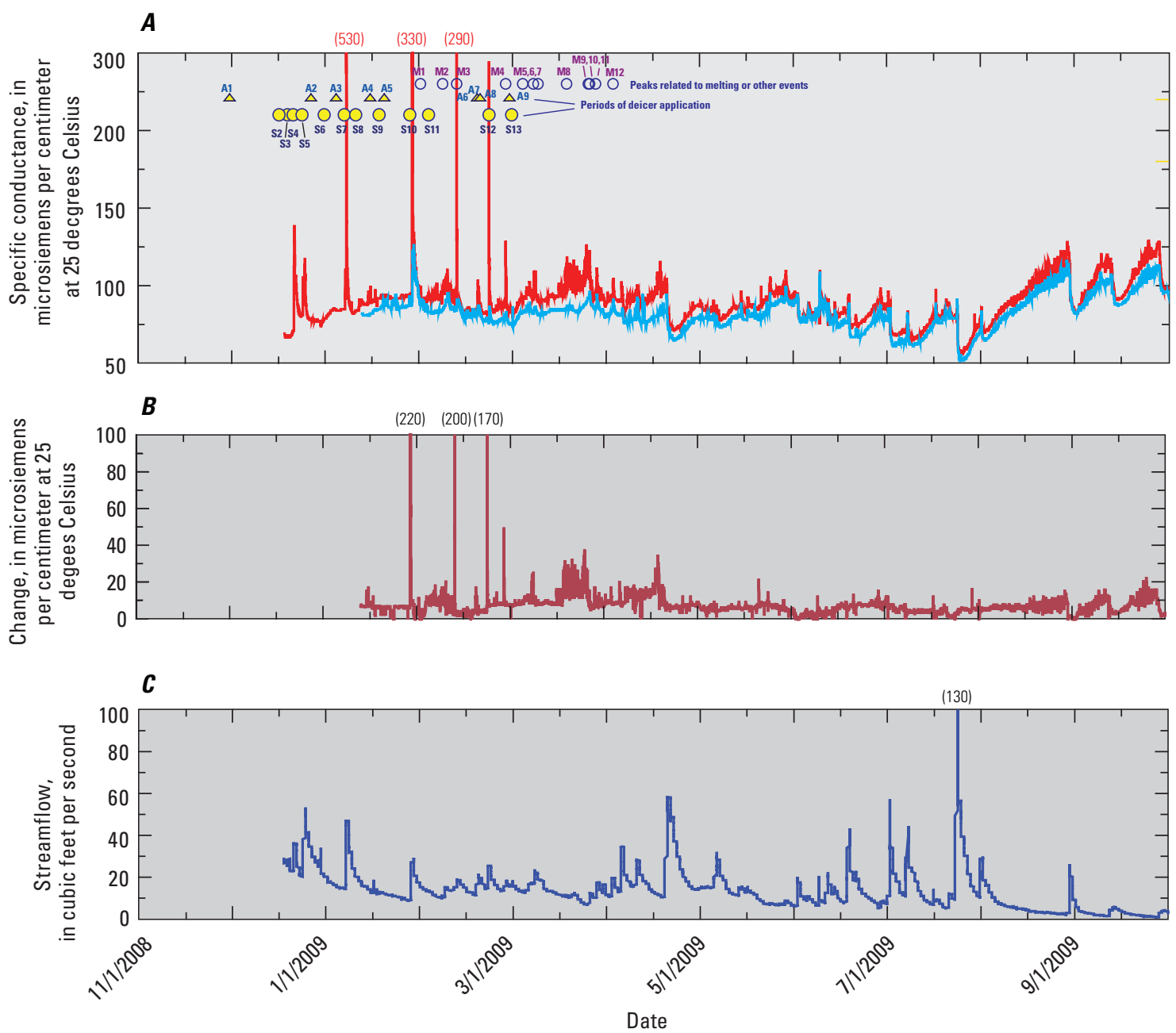

EXPLANATION

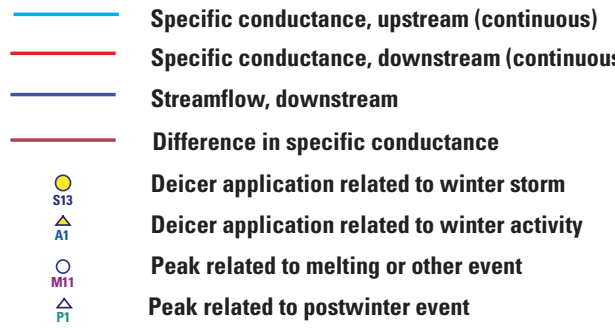

Letter and number codes are listed in table 5.

Numbers in parentheses indicate values that are off scale.

Figure 2-1. A, Specific conductance at upstream and downstream sites, and periods of deicer application and melting or other event, $B$, change in specific conductance between the upstream and downstream sites, and $C$, streamflow at Four Mile River, southeastern Connecticut, from November 2008 to September 2009. 

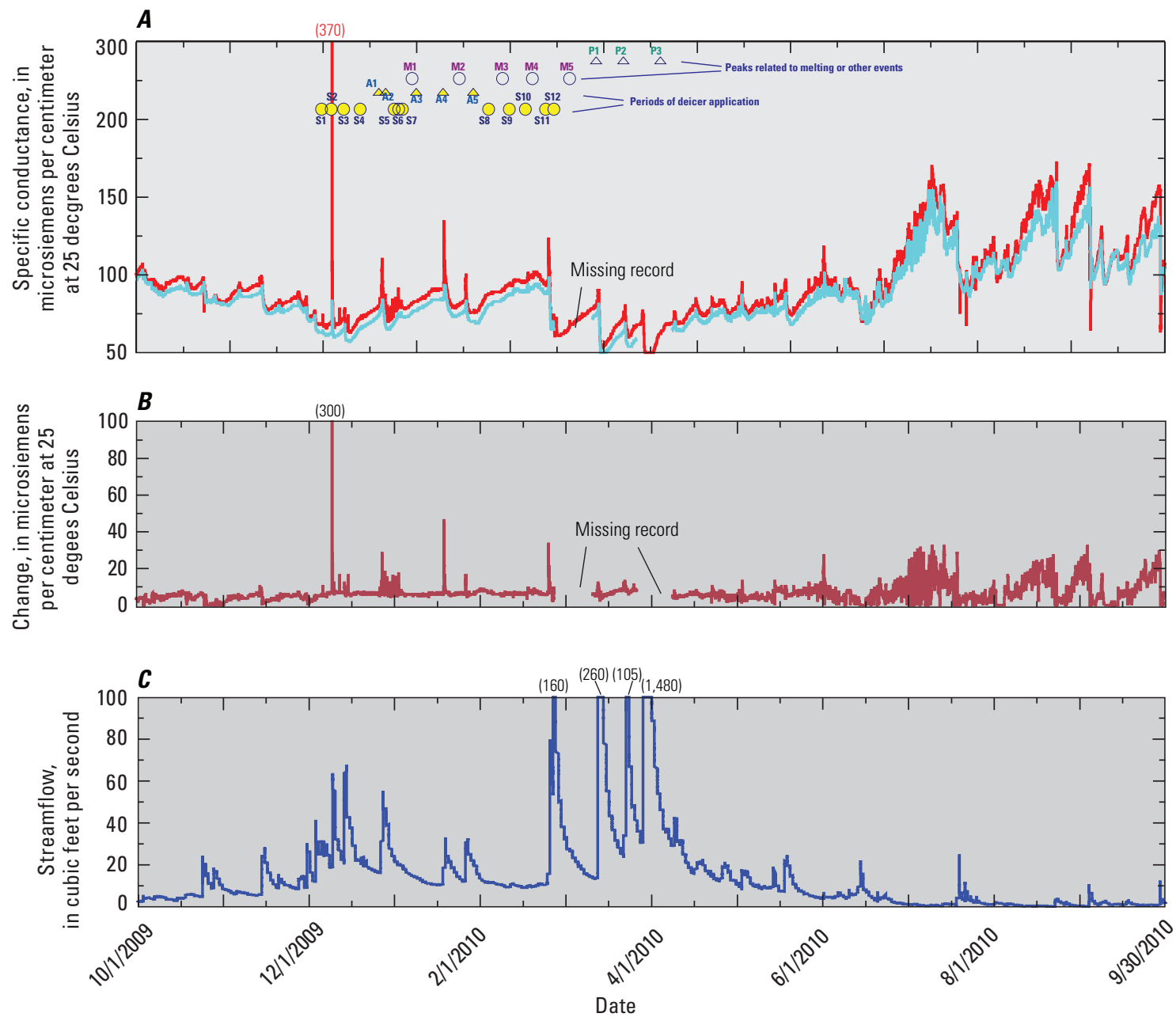

\section{EXPLANATION}

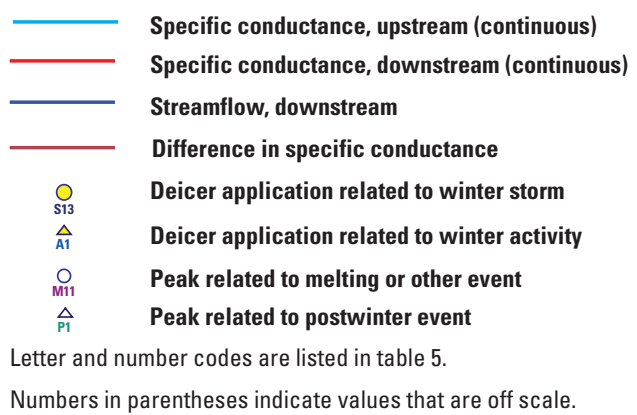

Figure 2-2. A, Specific conductance at upstream and downstream sites, and periods of deicer application and melting or other event, $B$, change in specific conductance between the upstream and downstream sites, and $C$, streamflow at Four Mile River, southeastern Connecticut, from October 2009 to September 2010. 

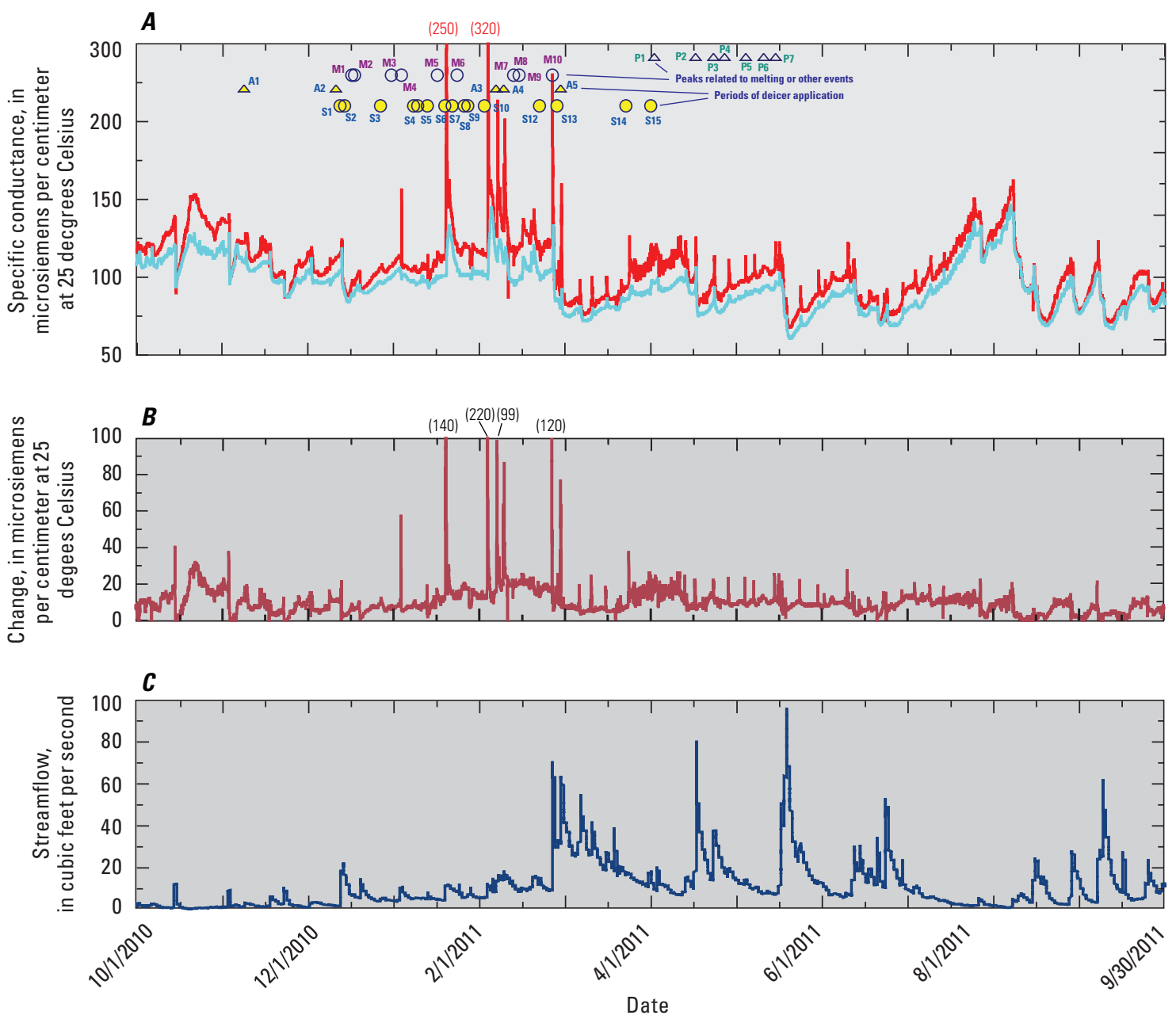

\section{EXPLANATION}

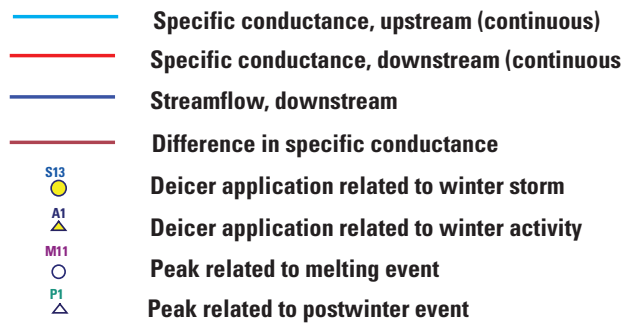

Letter and number codes are listed in table 5.

Numbers in parentheses indicate values that are off scale.

Figure 2-3. A, Specific conductance at upstream and downstream sites, and periods of deicer application and melting or other event, $B$, change in specific conductance between the upstream and downstream sites, and $C$, streamflow at Four Mile River, southeastern Connecticut, from October 2010 to September 2011. 


\section{Appendix 3. Specific Conductance Measurements and Streamflow at Oil Mill Brook, Southeastern Connecticut, from November 2008 to September 2011}
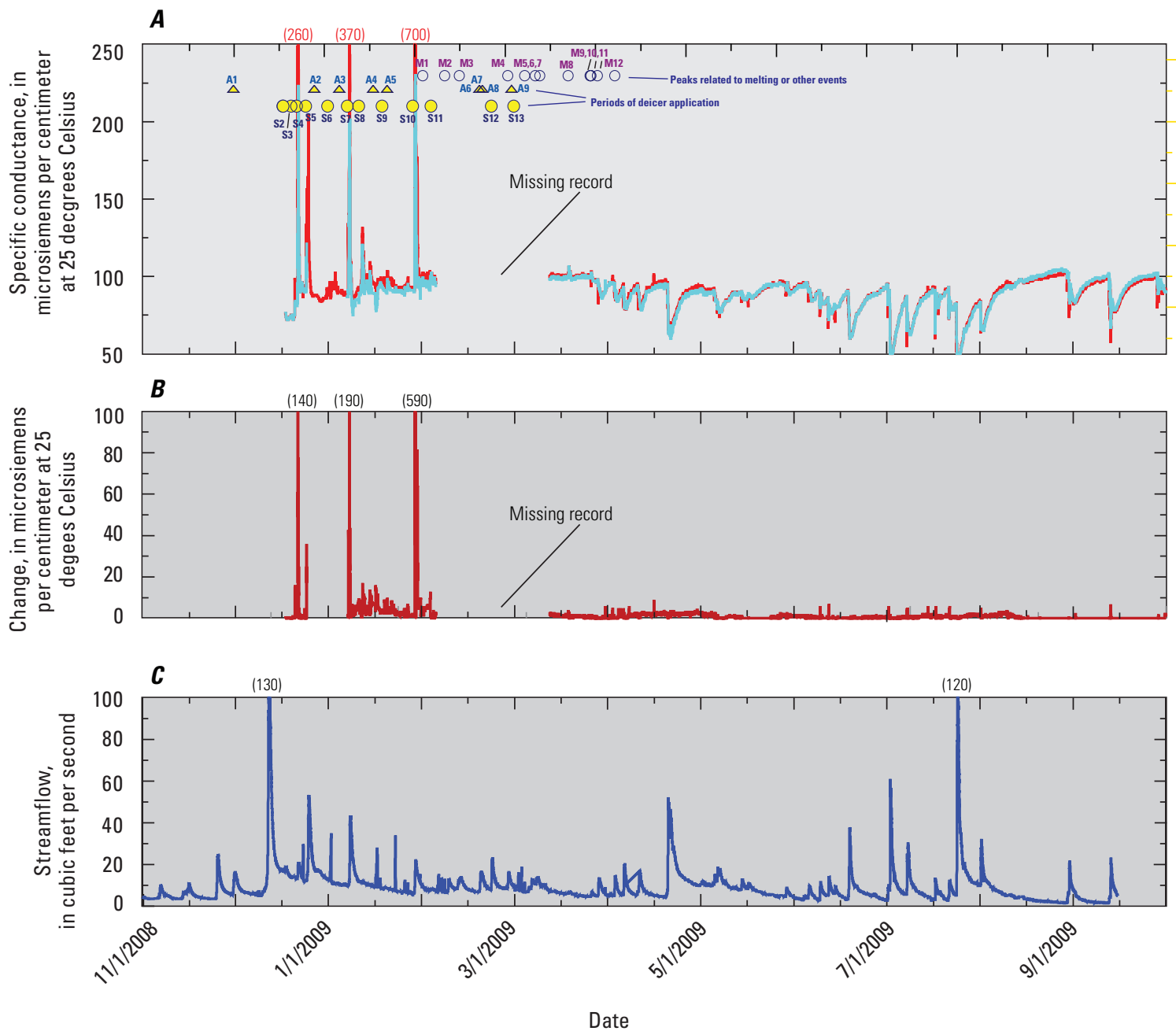

EXPLANATION

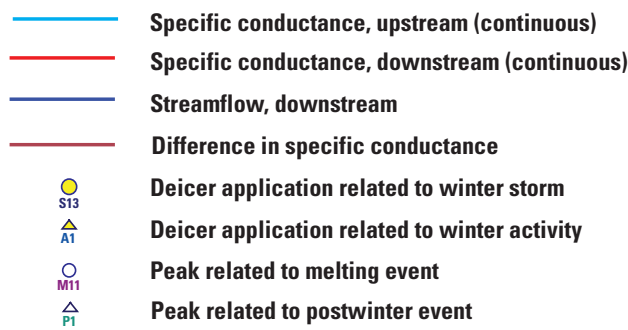

Letter and number codes are listed in table 5.

Numbers in parentheses indicate values that are off scale.

Figure 3-1. A, Specific conductance at upstream and downstream sites, and periods of deicer application and melting or other event, $B$, change in specific conductance between the upstream and downstream sites, and $C$, streamflow at Oil Mill Brook, southeastern Connecticut, from November 2008 to September 2009. 

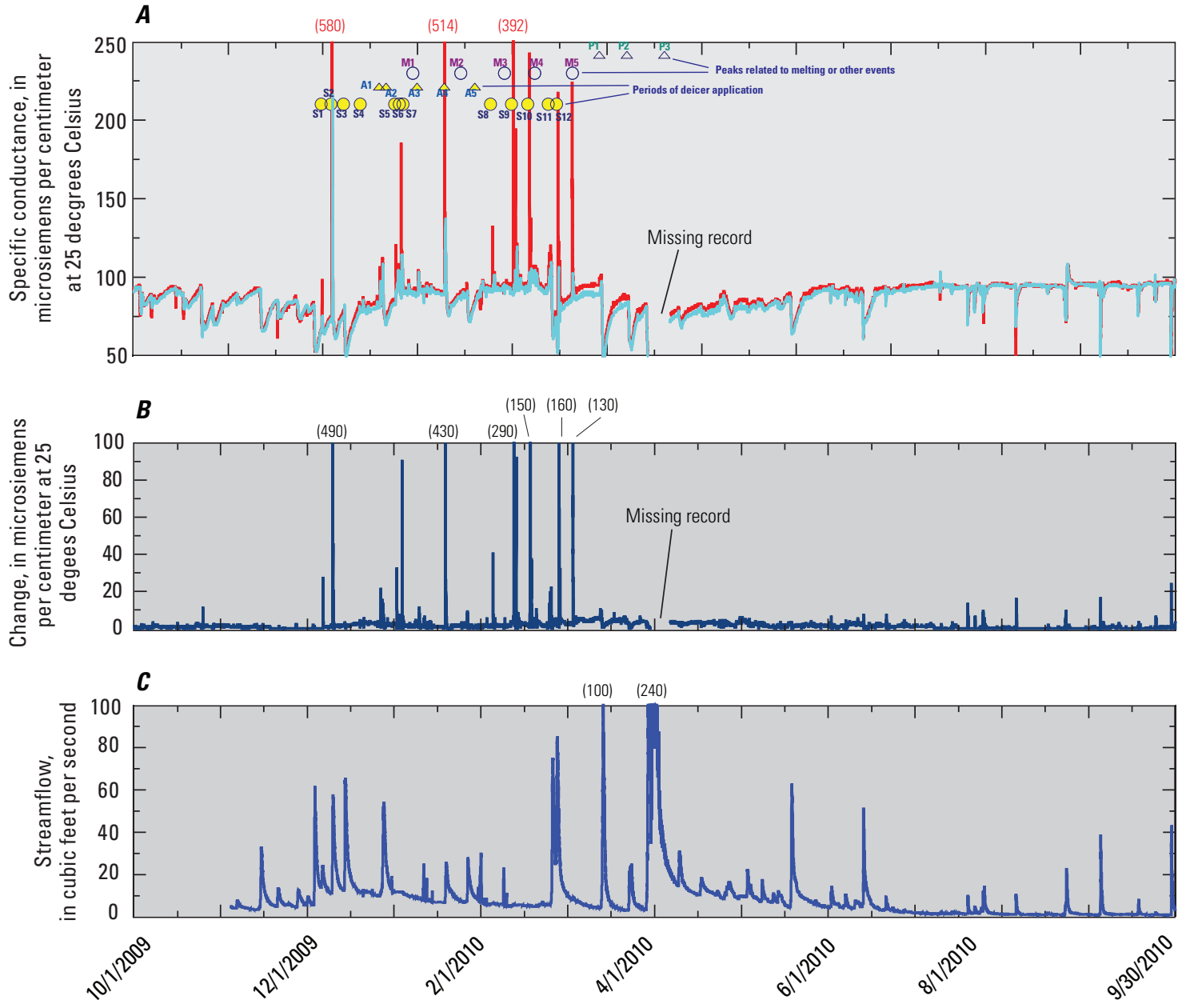

Date

EXPLANATION

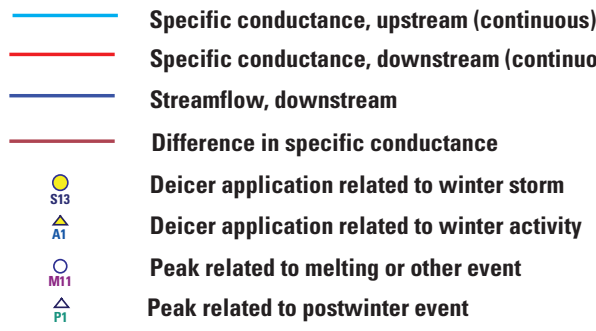

Letter and number codes are listed in table 5.

Numbers in parentheses indicate values that are off scale.

Figure 3-2. A, Specific conductance at upstream and downstream sites, and periods of deicer application and melting or other event, $B$, change in specific conductance between the upstream and downstream sites, and $C$, streamflow at Oil Mill Brook, southeastern Connecticut, from October 2009 to September 2010. 


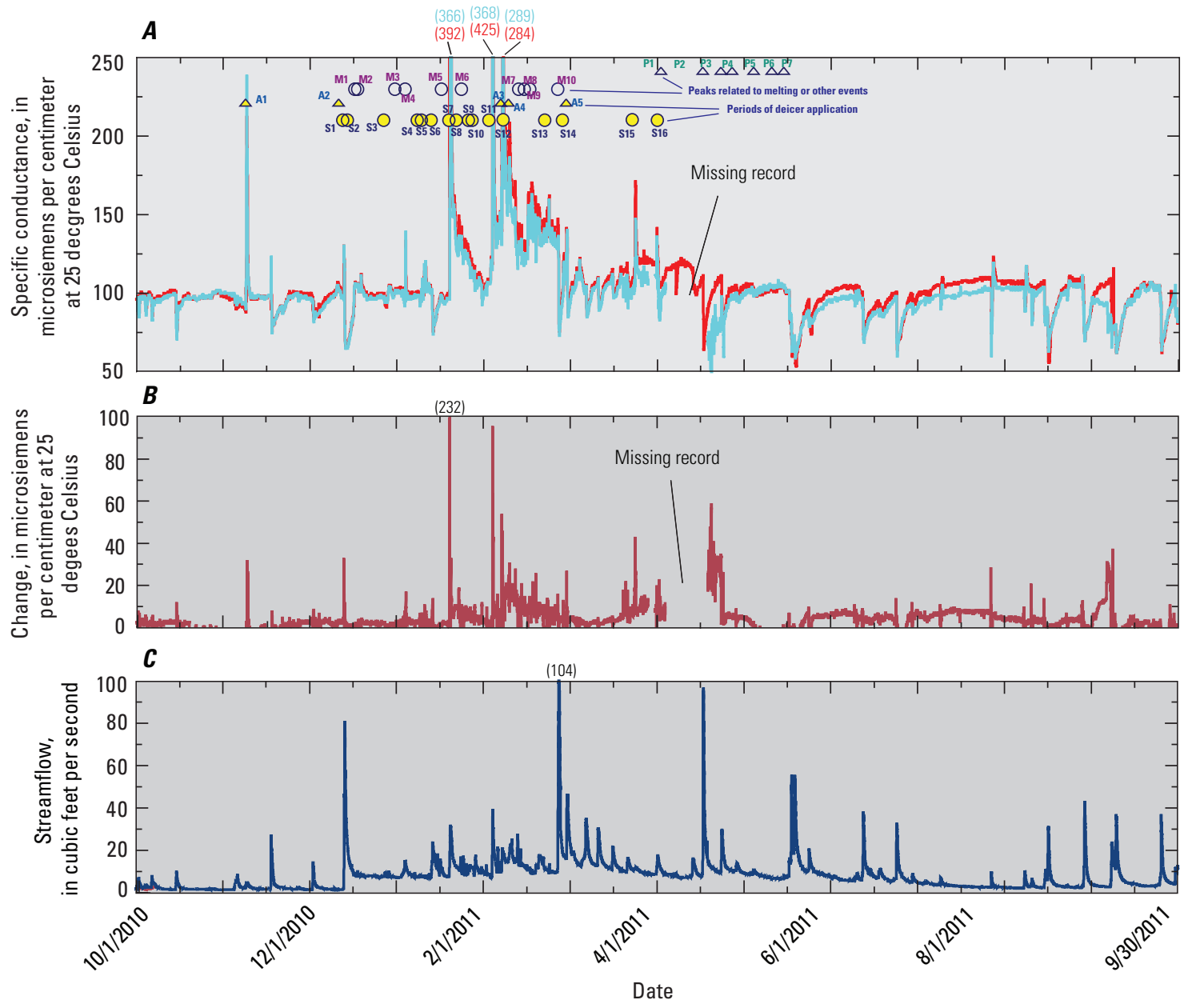

\section{EXPLANATION}

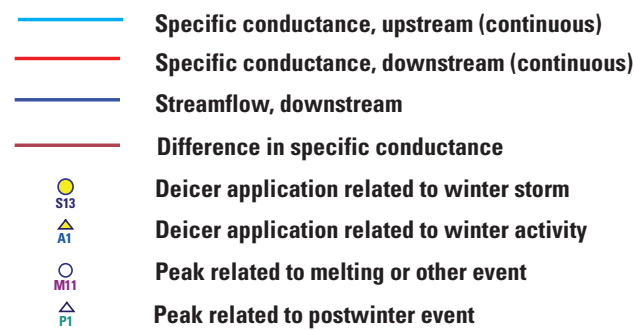

Letter and number codes are listed in table 5.

Numbers in parentheses indicate values that are off scale.

Figure 3-3. A, Specific conductance at upstream and downstream sites, and periods of deicer application and melting or other event, $B$, change in specific conductance between the upstream and downstream sites, and $C$, streamflow at Oil Mill Brook, southeastern Connecticut, from October 2010 to September 2011. 


\section{Appendix 4. Specific Conductance Measurements and Streamflow at Stony Brook, Southeastern Connecticut, from November 2008 to September 2011}
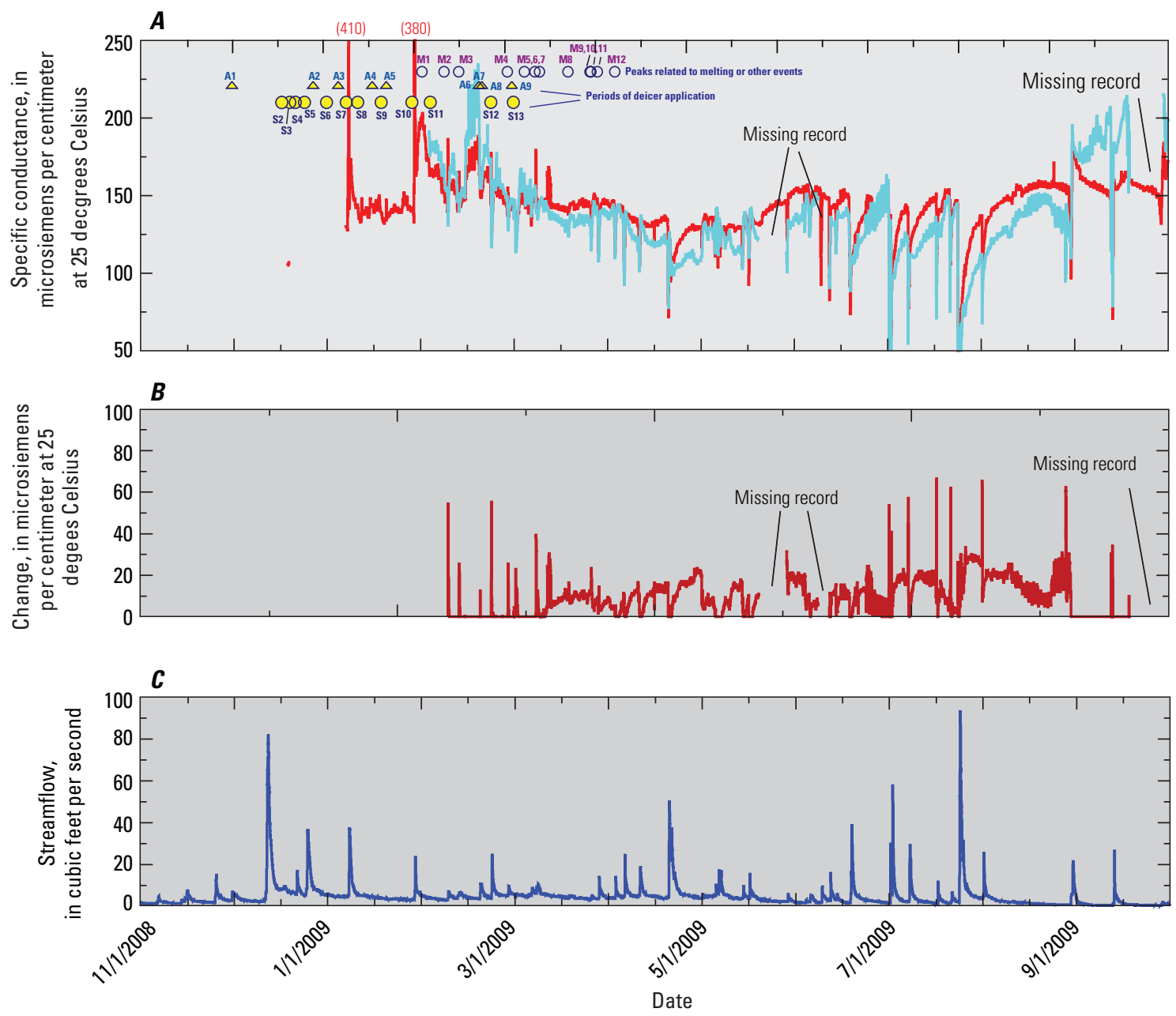

EXPLANATION

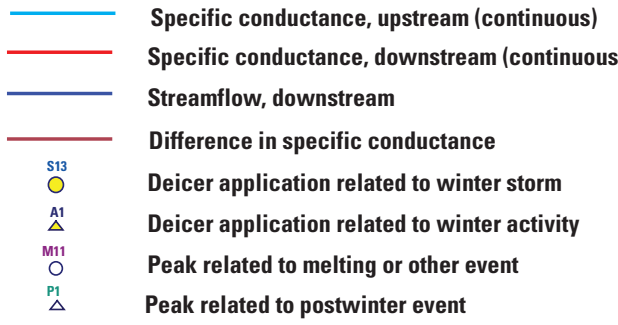

Letter and number codes are listed in table 5.

Numbers in parentheses indicate values that are off scale.

Figure 4-1. A, Specific conductance at upstream and downstream sites, and periods of deicer application and melting or other event, $B$, change in specific conductance between the upstream and downstream sites, and $C$, streamflow at Stony Brook, southeastern Connecticut, from November 2008 to September 2009 

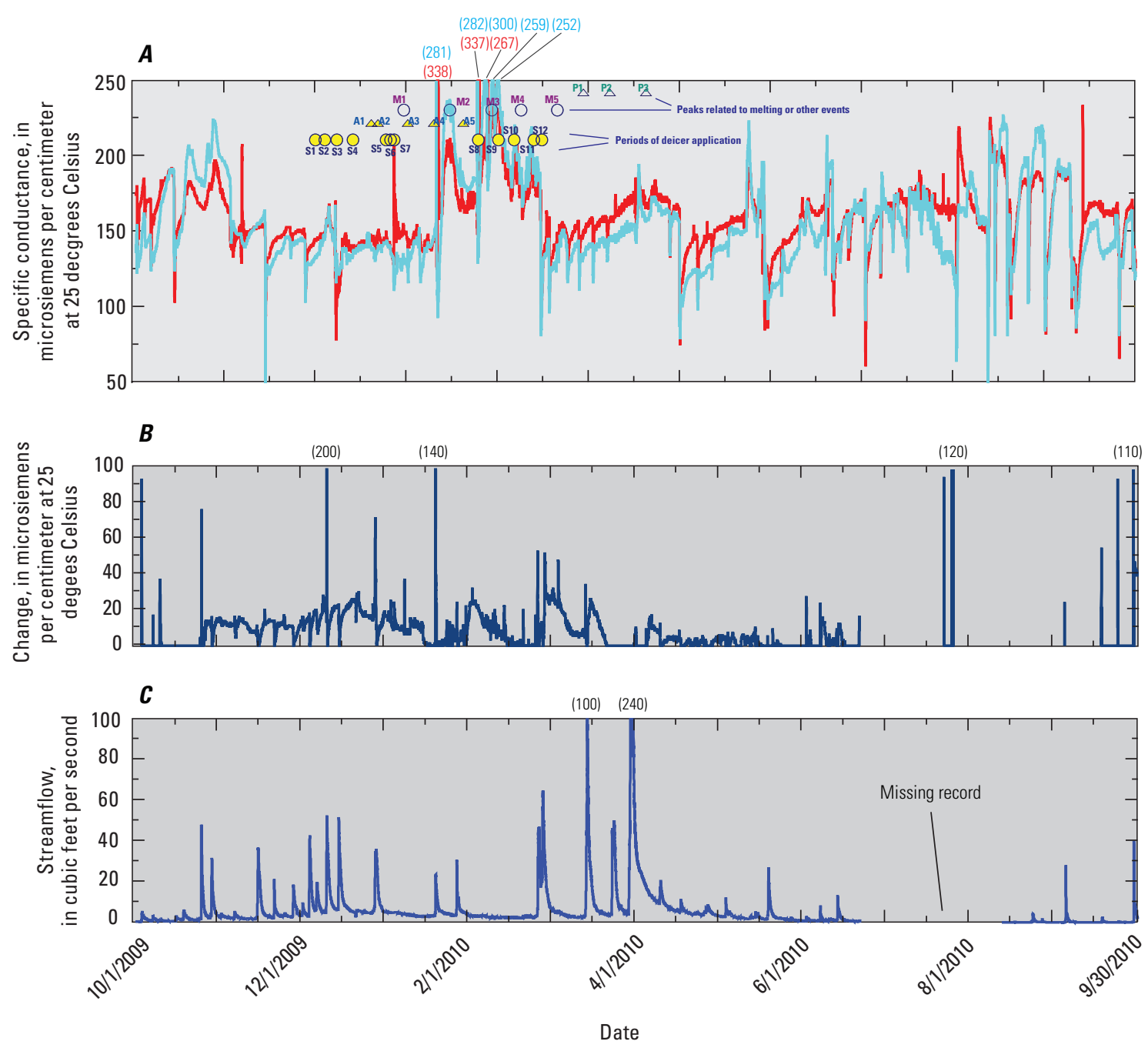

\section{EXPLANATION}

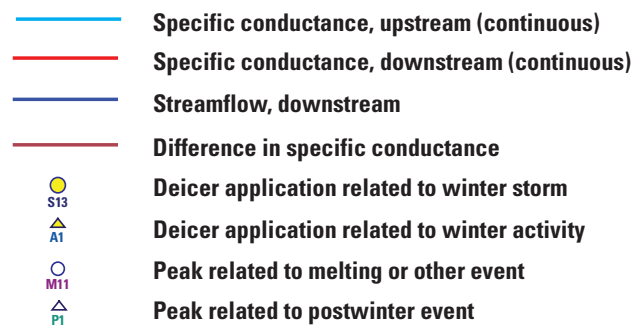

Letter and number codes are listed in table 5.

Numbers in parentheses indicate values that are off scale.

Figure 4-2. A, Specific conductance at upstream and downstream sites, and periods of deicer application and melting or other event, $B$, change in specific conductance between the upstream and downstream sites, and $C$, streamflow at Stony Brook, southeastern Connecticut, from October 2009 to September 2010. 

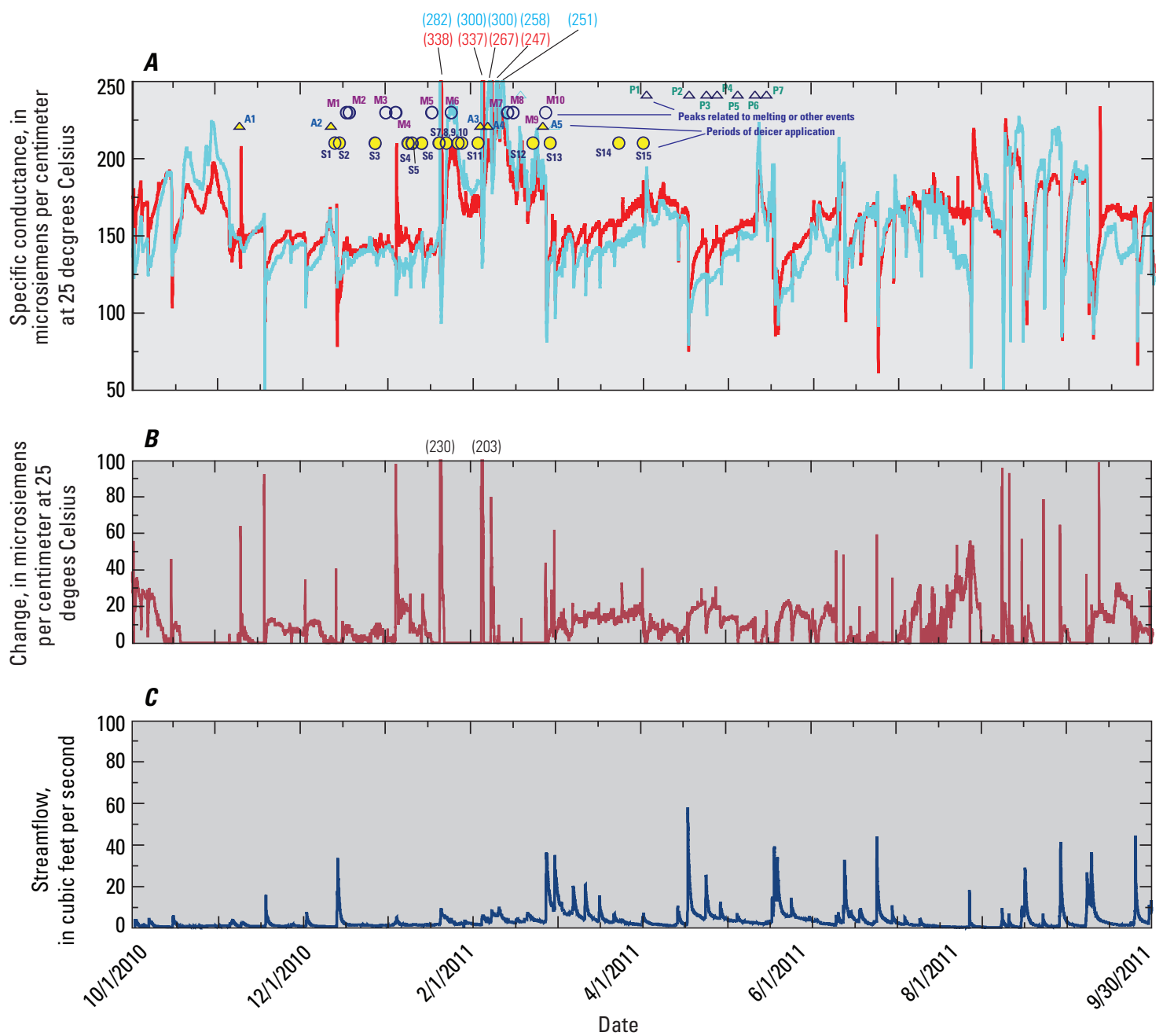

\section{EXPLANATION}

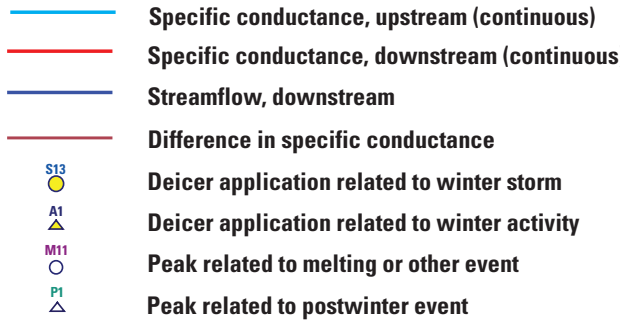

Letter and number codes are listed in table 5.

Numbers in parentheses indicate values that are off scale.

Figure 4-3. A, Specific conductance at upstream and downstream sites, and periods of deicer application and melting or other event, $B$, change in specific conductance between the upstream and downstream sites, and $C$, streamflow at Stony Brook, southeastern Connecticut, from October 2010 to September 2011. 


\section{Appendix 5. Specific Conductance Measurements and Streamflow at Jordan Brook, Southeastern Connecticut, from November 2008 to September 2011}
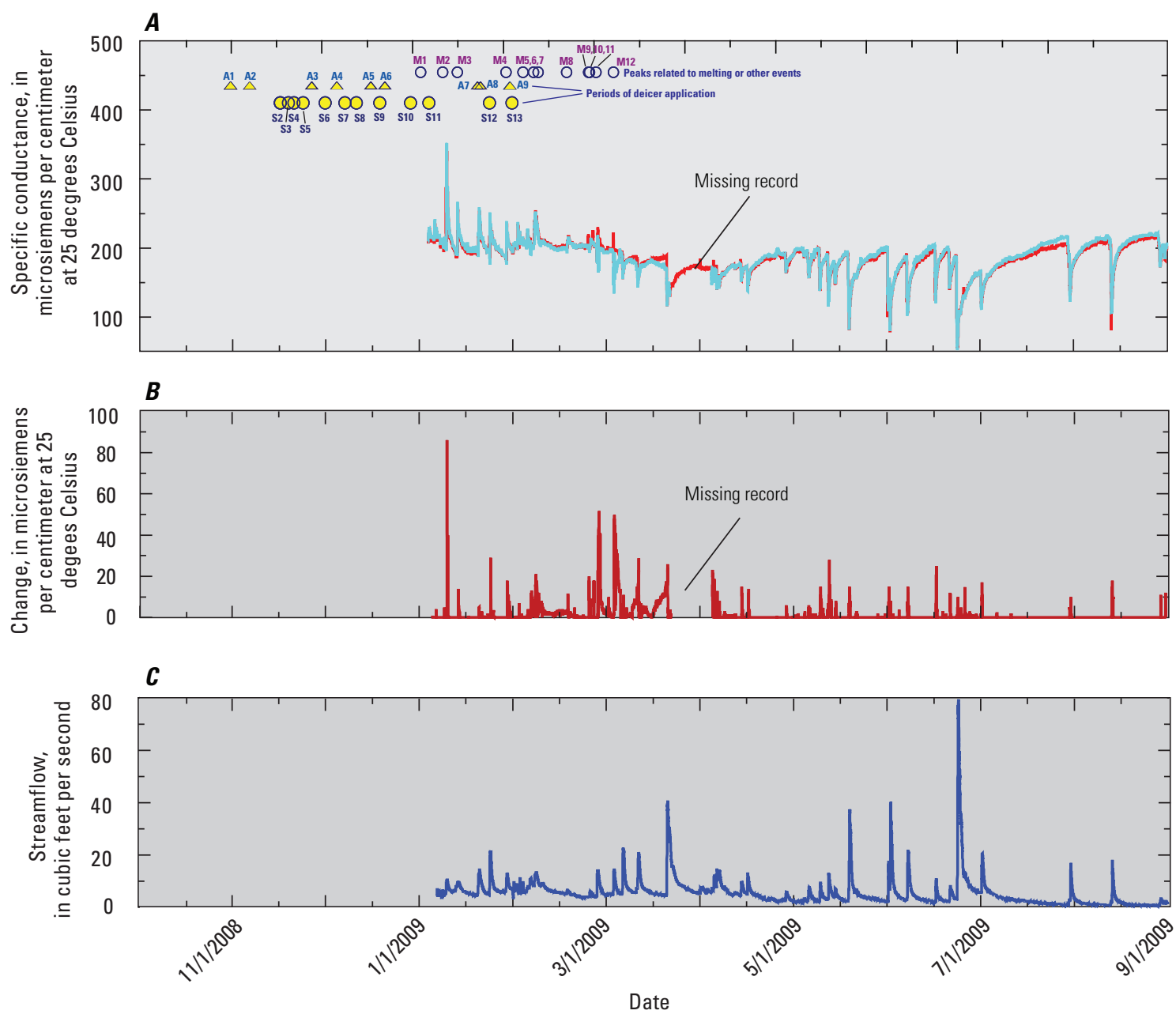

\section{EXPLANATION}

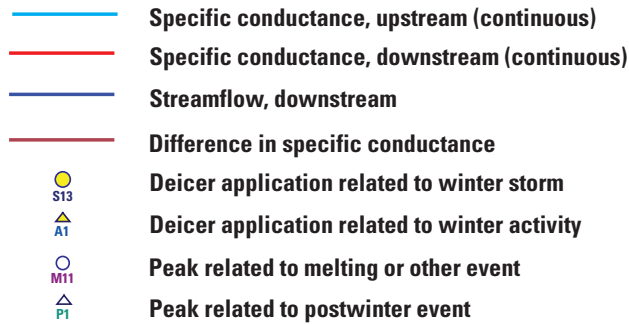

Letter and number codes are listed in table 5.

Figure 5-1. A, Specific conductance at upstream and downstream sites, and periods of deicer application and melting or other event, $B$, change in specific conductance between the upstream and downstream sites, and $C$, streamflow at Jordan Brook, southeastern Connecticut, from November 2008 to September 2009. 

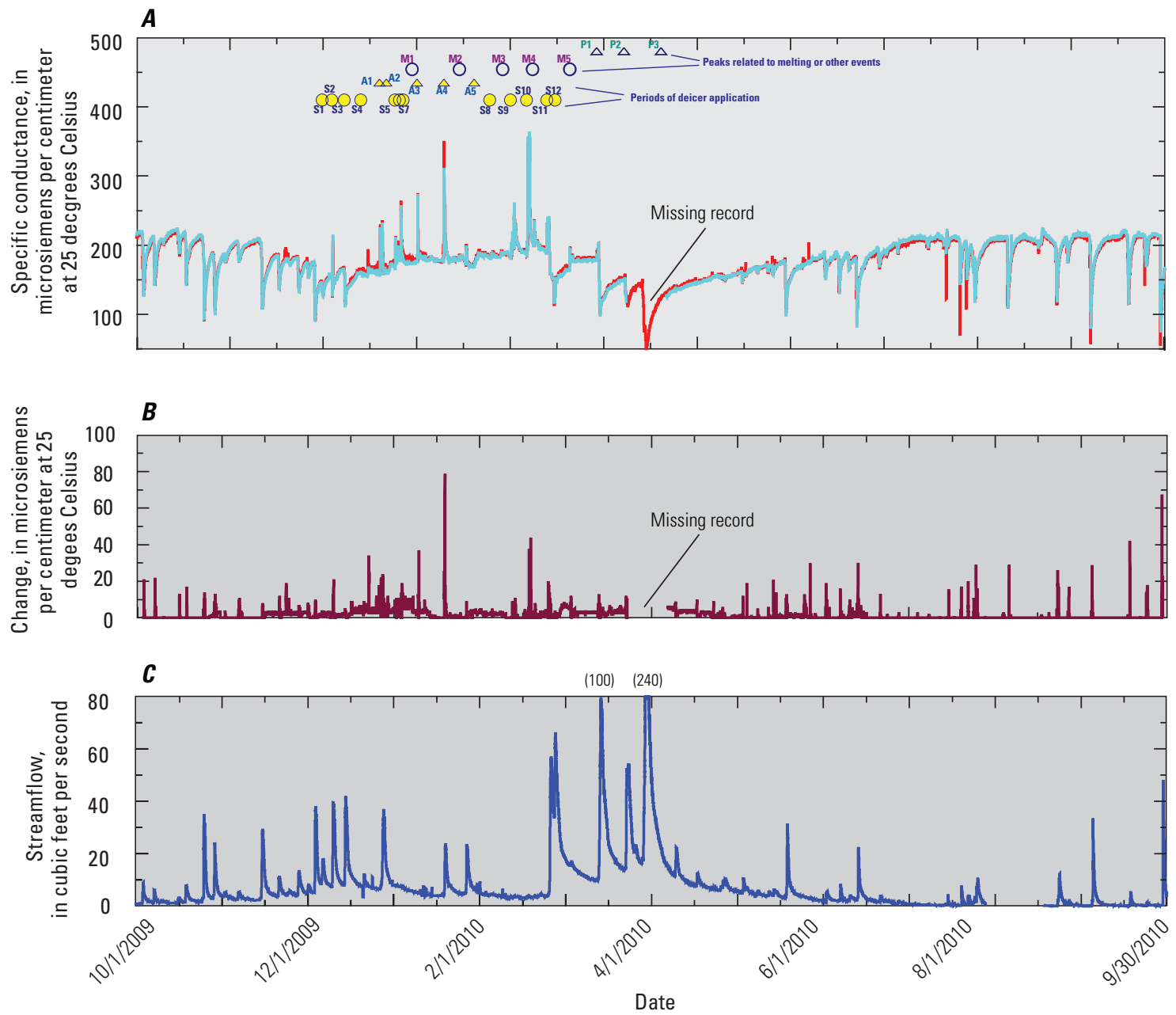

EXPLANATION

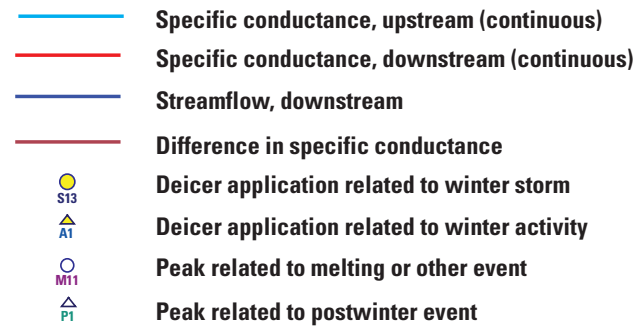

Letter and number codes are listed in table 5.

Numbers in parentheses indicate values that are off scale.

Figure 5-2. A, Specific conductance at upstream and downstream sites, and periods of deicer application and melting or other event, $B$, change in specific conductance between the upstream and downstream sites, and $C$, streamflow at Jordan Brook, southeastern Connecticut, from October 2009 to September 2010. 

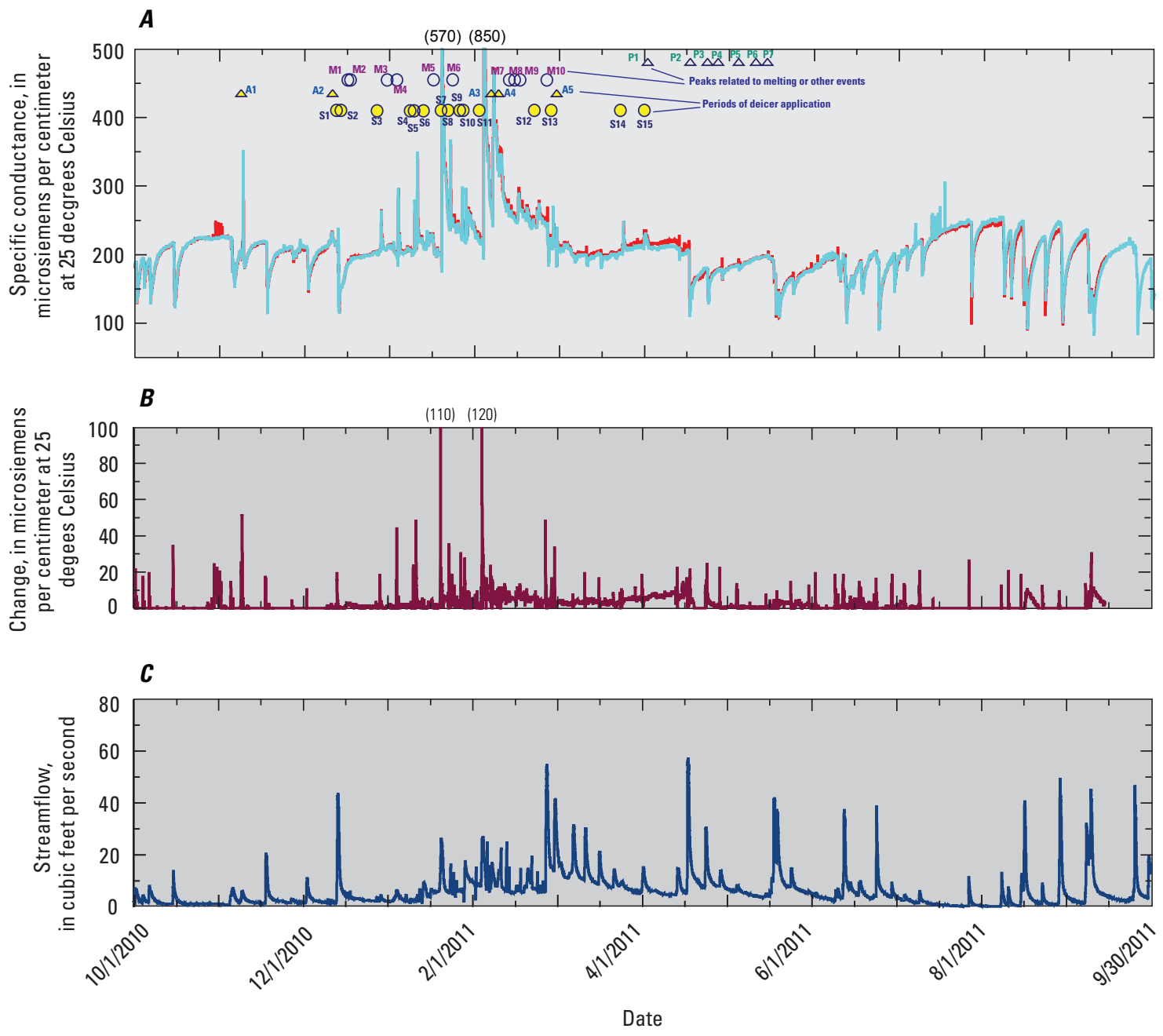

\section{EXPLANATION}

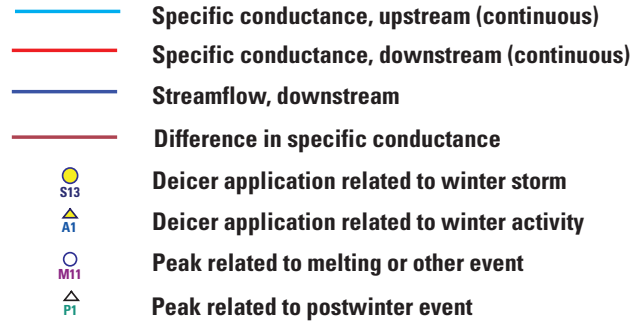

Letter and number codes are listed in table 5.

Numbers in parentheses indicate values that are off scale.

Figure 5-3. A, Specific conductance at upstream and downstream sites, and periods of deicer application and melting or other event, $B$, change in specific conductance between the upstream and downstream sites, and $C$, streamflow at Jordan Brook, southeastern Connecticut, from October 2010 to September 2011. 
For more information concerning this report, contact: Director, New England Water Science Center U.S. Geological Survey 101 Pitkin Street

East Hartford, CT 06108 dc_nweng@usgs.gov or visit our Web site at: http://ct.water.usgs.gov

Publishing support by:

The Pembroke and West Trenton Publishing Service Centers. 


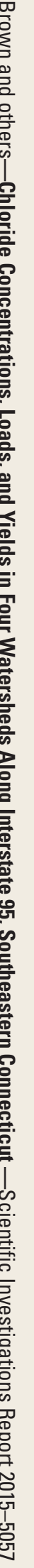

